\title{
RECETARIO MORISCO MÉDICO-HIPIÁTRICO
}

\author{
Concepción Vázquez de Benito* \\ Teresa de Bustos*
}

\section{EL MANUSCRITO: DESCRIPCIÓN, PROCEDENCIA Y CONTENIDO}

El manuscrito objeto de nuestro estudio y edición pertenece en la actualidad a la Biblioteca de la Facultad de Filología de la Universidad de Salamanca, incluido en ella dentro del conjunto de los libros que forman el legado de don Ricardo Espinosa Maeso'. Se halla encuadernado en pergamino, consta de 68 páginas en papel, su superficie escrita es de 12 por 10 $\mathrm{cm}$, deteriorado a veces el texto por la humedad; con foliación antigua a tinta (pp. 1-9), continuada con la moderna a lápiz (pp. 10-67), por haber desaparecido la antigua al estar corroídos los márgenes.

Es de autor desconocido y está inconcluso. Al dorso de la primera tapa se escribe en cifras árabes el n. ${ }^{\circ}$ 168, y en la primera página, en castellano, "Fragmento de Medicina hallado en Alcázar de Consuegra”. Siguen a ésta cuatro páginas en blanco, la quinta está encabezada con el siguiente título redactado en árabe: Libro que contiene temas concernientes a veterinaria y asuntos semejantes que revisten gran utilidad.

Tras este epígrafe viene la descripción de un medicamento; su caligrafía es distinta a la del resto del texto, mucho más pequeña, magrebí, toda ella en negrita, sin vocalizar, y menos tardía que la caligrafía del resto del manuscrito, el cual está también en grafía de tipo magrebí, de rasgos muy grandes, con encabezamientos en rojo y con expresión de vocales. En suma, una caligrafía propia de época tardía, usada ampliamente entre los musulmanes españoles del siglo $\mathrm{XV}$ y entre los moriscos del siglo $\mathrm{XVI}^{2}$.

* $\quad$ Universidad de Salamanca.

1. Cf. María de la CONCEPCIÓN VÁZQUEZ DE BENITO: «Sobre un manuscrito árabe hallado en Alcázar de Consuegra», en Homenaje a María Jesús Rubiera, Sharq al-Andalus, 10-11, 1993-94, pp. 711-720.

2.

Ron Barkai, quien asimismo ha hecho el estudio y edición de un texto de medicina morisca del siglo XVI existente en la B.N. de Madrid (caja 18.585 XXI) descrito como "Fragmento de 
En cuanto a su procedencia, cabe advertir en primer lugar que Alcázar de Consuegra es identificada por P. Madoz ${ }^{3}$ con Alcázar de San Juan, villa que pertenece a la provincia de Ciudad Real. Esto nos hace pensar en su procedencia granadina, ya que las fuentes históricas señalan que tras la rebelión de las Alpujarras (1568-1570) los moriscos granadinos a partir de noviembre de 1570 fueron conducidos del reino de Granada hacia Castilla y que los instalados en Alcázar de San Juan y Consuegra procedían del Marquesado de Cenete y Benamuruel ${ }^{4}$. Así pues, el idioma árabe olvidado en Castilla o cuasi, vuelve con la deportación de los granadinos ${ }^{5}$.

un formulario farmacéutico", 11 fols. (en prensa), se refiere al tratado diciendo: "It is nevertheless clear beyond all doubt that this treatise was composed during the decline of the Arabic language among the moriscos. It is written in broken Arabic, full of mistakes, and its vocabulary is highly restricted. Besides these decaden tendencies, the treatise includes a considerable number or word of Castilian-Romance origin-narres of diseases, remedies, plants and herbs, articles of clothing, etc. Throughout the text, I identifie 27 words which are indisputable in Arabic, rather than aljamiado... the linguistic acculturation of de moriscos, as evidenced by infiltration of Castilian word intho the written Arabic used among morisco medical practioners". Y B. VICENT, «Reflexión documentada sobre el uso del árabe y de las lenguas románicas en la España de los Moriscos (ss. XVI-XVII)», en Homenaje a María Jesús Rubiera, Sharq al-Andalus, 10-11, 1993-94, pp. 731-748, dice: “El concepto del Islam affaibli ('islam debilitado') que ha sacado a relucir Leila Sabbag, se aplica perfectamente a la lengua utilizada por los moriscos en el giro de los siglos XVI y XVII. Los interesados no midieron probablemente la amplitud de la degradación hasta que se vieron en el exilio en 1609 , pero sin duda ya tendrían algo de conciencia de ello antes".

3. Pascual MADOZ, Diccionario geográfico-estadístico-histórico de España y sus posesiones de ultramar, tomo I, Madrid, 1846.

4. A. Domínguez OrTiZ y B. Vicent, Historia de los Moriscos. Vida y tragedia de una minoría, Madrid, 1978, pp. 50-56. B. VINCENT, «L'Expulsion des morisques de Royaume de Granada et leur répartition en Castilla (1570-1571)», Mélanges de la Casa de Velázquez, 6, 1970, pp. 211-246, y «La expulsión de los moriscos del Reino de Granada y su reparto en Castilla», en Andalucía en la Edad Moderna, Granada, 1976, p. 104. I. GARCíA BALLESTER, Medicina, ciencia y minorías marginadas, Granada, 1976, p. 104, dice: "La diáspora de los moriscos granadinos por Castilla, llevó a estas tierras de forma aguda el problema morisco".

5 .

María Jesús Viguera en el Prólogo de Relatos píos y profanos del ms. aljamiado de Urrea de Jalón, de P. CORRIENTE, Zaragoza, 1990, p. 17, señala: "los moriscos valencianos y granadinos utilizaban la lengua árabe de forma cotidiana, la hablaban, la empleaban en todo tipo de escritos, públicos y privados [...] frente a moriscos aragoneses y castellanos que habían perdido la lengua árabe, y al perderla, recurrieron al aljamiado, es decir, a escribir la lengua romance que hablaban (castellano con aragonesismos) con grafemas árabes". Y A. LABARTA en «Inventario de los documentos árabes contenidos en procesos inquisitoriales contra moriscos valencianos conservados en el archivo histórico nacional de Madrid (legajos 548-556)», al-Qantara, Madrid, vol. I, fase. 1 y 2, 1980, pp. 152-153, afirma también: "La ausencia de documentación aljamiada en Valencia es un hecho que no debe sorprendernos: el procedimiento de escribir en romance utilizando el alfabeto árabe carece de sentido en el contexto de la población morisca valenciana, arabófona y con escasos conocimientos de romance. No así en Aragón y Castilla, donde los moriscos, perdido el árabe, hablaban el castellano igual que los cristianos viejos [...]

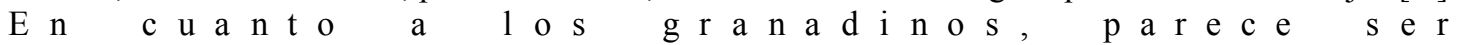
que conservaron la lengua árabe”. En 1605 el padre Ignacio de las Casas describió así las diferencias lingüísticas entre los varios grupos de moriscos: "los del Reyno de Toledo no saben ni entienden palabra de la lengua Arábiga; los Tangarinos [...] tampoco saben ni entienden la lengua 
En cuanto al contenido, como expresa el título, versa de Medicina y Veterinaria, porque contiene un total de 126 recetas curativas sobre diversos males propios ya del ser humano, ya del animal, si bien en muchos casos in distintamente podría tratarse de uno u otro, puesto que la Medicina Veterinaria contiene en sus descripciones muchas semejanzas con la Medicina Humana $^{6}$. Más aún, ambas materias, a nivel práctico en esos siglos, andaban muy mezcladas, por lo que resulta casi imposible trazar un deslinde claro de dos tradiciones que van entrecruzándose. Así:

\section{MEDICINA}

- Un remedio para los ojos (I).

- Las verrugas $(12,18,19,71,101)$.

- La hemorragia nasal $(63,98)$.

- El crecimiento del pelo $(64,83)$.

- La herida, la mordedura del perro o la contusión (65).

- La sarna $(67,84)$.

- Las escrófulas (68).

- Las heridas con gusanos (69).

- El enrojecimiento de ojos (72).

- Las lombrices intestinales (73).

- La inflamación de los cojones (74).

- Las hemorroides y el prurigo (79).

- La extracción de dientes sin hierro (70).

- Las sanguijuelas en la garganta (81).

- La extracción de astillas, huesos o espinas (82).

- La picadura de escorpión, reptil u otro animal venenoso (85).

- Las grietas en los talones (86).

- El tumor duro $(87,89)$.

- La contusión por espada o cuchillo (90).

- La enfermedad de la espina (90).

- La mordedura de perro rabioso (91).

Arábiga ni sus mugeres ni sus hijos. Con éstos de Aragón se juntan todos los moriscos del Reyno de Valencia: y la differencia que entre ellos ay consiste en que los de Valencia hablan la lengua Arábiga y son raros dellos los que entienden bien la española [...] los más dente Reyno saben leer y escrevir su lengua arábiga".

6. Cf. H. EINSENSTEIN, «Las obras árabes de Medicina Veterinaria: ¿Tratados médicos o literatura edificante?», Actas XVI Congreso HEAI, Salamanca, 1995, p. 162. 
- La hinchazón de las piernas (92).

- Los signos de la sangre (94).

- Cómo cerrar las heridas con hilo (95).

- La inflamación de las venas por sangría (96).

- El chancro (97).

- Cómo detener la hemorragia de las heridas (113).

- Cómo hacer salir la pus de las heridas (117).

- La diarrea y el vómito de los niños (28).

- La diarrea de los mayores (29).

- El dolor de ojos en los niños (30).

- La hernia testicular (31).

- El vómito (30).

- La evacuación de los humores del cerebro $(33,35)$.

- El feto muerto en el vientre de la madre (34).

- El albarazo (36).

- La acumulación de varices (57).

- La disuria (68).

- La inflamación del nervio (116).

\section{VETERINARIA}

- Cómo conocer la edad de las bestias (2).

- La cauterización (3).

- La despeadura $(77,104)$.

- La torsión (5).

- La reticulación y el dájaso $(7,8,9,78,120)$.

- La esquinancia o angina (10).

- La hematuria (11).

- Cómo extirpar los gusanos de las heridas (13).

- Una receta de magia oral (14).

- La curación del asma o del ahogo (15).

- La caída de las cerdas del copete (16).

- La sofocación interna $(17,109,124)$.

- La salida del intestino (20).

- El animal debilitado (21).

- La uña en los ojos $(22,45,119)$.

- La mancha blanca en los ojos $(23,52,61,99,106,110,118)$. 
- Las adivas (25).

- La carúncula $(26,61)$.

- Sobre cualquier mal en el casco (27).

- El sobrehueso o masa $(37,61,103)$.

- La sangría de las venas $(38,39,40,41,42)$.

- El torzón $(44,48,123)$.

- El lobado (46).

- Las vejigas (47).

- Las heridas con inflamación (49).

- La inflamación de párpados o barba (50).

- El muermo $(51,126)$.

- El higo (53).

- Las ajuagas $(54,93)$.

- La contorsión (56).

- Los beneficios de la alholva (75).

El tratado incluye además (fols. 4v. a 8v.) los días fastos y nefastos, es decir, los días favorables o desfavorables del mes, los cuales influidos por un astro o constelación tenían ciertas virtudes y son a propósito para cosas distintas: comprar, vender, embarcarse, casarse, edificar, ponerse enfermo, sangrarse, visitar al sultán, etc., citándose a Adán, Eva, Noé, Set e Isaac, personajes usualmente mencionados por los moriscos en sus plegarias para pedir a Dios perdón por sus pecados. Concretamente esto se halla en la rogativa tercera ${ }^{7}$. También se cita al Faraón y las plagas de Egipto $^{8}$.

7. Así, P. Longas, Vida religiosa de los moriscos, Madrid, 1915, p. 167, recoge: "Por las vestiduras de Adán [...] Por la corona de Eva [...] Por las cartas de Set [...] Por la ascensión de Enoc al cielo".

8. A. LABARTA en Libro de dichos maravillosos (Misceláneo Morisco de magia y adivinación), Madrid, 1993, p. 28, señala: "En los folios 31v.-344v. tenemos un capítulo dedicado a los días favorables o desfavorables del mes [...] Este capítulo presenta numerosas similitudes en su redacción con un tratadito de hemerología atribuido a $\hat{Y}^{c}$ far al-Sādiq, referido al mes solar (Ebied/Young 1976). Se ha conservado en un manuscrito de Java del siglo XIX (Witkan 1979). Aparte de la coincidencia general en el carácter fasto/nefasto de cada uno de los días, hay otras coincidencias más puntuales, por ejemplo que 'el día 24 nació el Faraón y por eso es día de gran desgracia; el día 25 fue el día en que Dios envió las plagas de Egipto' [...] Nuestro texto igualmente coincide en cuestiones puntuales como es que el día 24 del mes nació el Faraón y que el día 25 Dios envió las plagas de Egipto, sin embargo no así en la mención de que en el día primero nació Adán y por eso es favorable; el día segundo nació Eva y por ello es así mismo favorable; en el día décimo nació Noé y por tanto es también favorable, etc.". 
Todo ello se basa en los asertos de Ŷa'far al-'Șādiq (148-765), sexto imam de la Ši 'a, -a su muerte precisamente se desgajan las dos principales ramas de ši 'ismo, el imamismo duodecimano y el ismailismo septimano-, cuya reputación de sabiduría trascendió las fronteras del ši 'ismo, siendo venerado por los propios adeptos de la sunna desde antiguos ${ }^{9}$.

Con todo, el material se presenta de forma desordenada, no sigue un orden establecido ni responde a una estructura determinada. Se trata de una mera recopilación de procedimientos curativos médico-hipiátricos que parecen haber sido reunidos al $\operatorname{azar}^{10}$.

\section{LAS FUENTES}

Las fuentes evidentes de nuestro texto y que hemos podido documentar son tres. El Libro de Agricultura del sevillano Ibn al-'Awwām, el Tratado de Hipiatría del granadino Ibn Hudayl, y, el Libro de la Almohada o Recetario médico de Ibn Wāfid de Toledo, de donde nuestro texto toma, como veremos, gran parte de los procedimientos curativos propios ya del ser humano ya del animal.

En cuanto a la primera fuente, es decir, el Libro de Agricultura de Ibn al-'Awwām, como se sabe, el volumen II del mismo contiene todo lo relativo al cuidado de los animales, -porque la literatura veterinaria está totalmente ligada a la literatura agrícola- ${ }^{11}$. Y, concretamente, las páginas 460 a la 692 tratan de los animales domésticos: ganado vacuno, lanar, cabra, mulo, asno, camello y caballo, de donde ha tomado precisamente el tratado morisco la fuente, si bien presentando todo ello -como veremos por los ejemplos aducidos- de forma incompleta y desordenada respecto al original árabe ${ }^{12}$.

9. Ibidem.

10. L. GARCÍA BALLESTER, Los moriscos y la Medicina. Un capitulo de la medicina y la ciencia marginada en la España del siglo XVI, Barcelona, 1984, p. 90, argumenta lo siguiente: "Esta ciencia médica -a nivel de sanador morisco- circulaba por los tres canales vistos de la transmisión oral, el empirismo y el contacto con una doble tradición escrita. Una de carácter muy popular pese a su origen científico más o menos cercano en el tiempo".

11. C. Álvarez de Morales y RuIz-Matas, Los animales en los textos agrícolas escritos en árabe, Miscellanea Arabica e Islamica, Leuven, 1993, pp. 143-163.

12. C. Álvarez de Morales y RuIZ-MAtAS, «Un tratado granadino de hipiatría», en Homenaje al Prof. D. Cabanelas Rodríguez, Granada, 1987, vol. II, p. 307: "En el siglo XII es de capital importancia la repetidamente citada obra de Ibn al- ${ }^{\mathrm{C}} \mathrm{Aww}$ ām, Kitab al-Filaha", trad. J. BANQUERO, El Libro de Agricultura, 2 vols., Madrid, 1802. En el volumen II (pp. 568-677) están dedicadas las páginas a la albeitería, y a la hipología las páginas comprendidas entre la 667 y 692. 
Recordemos al respecto que, como afirma Millás, “la obra de Ibn al-'Awwām fue como el canto del cisne de toda esta escuela geopónica árabe, obra que viene a ser como el receptáculo de todas sus experiencias y hallazgos [...] es, en verdad, como la suma o compendio de toda agricultura hispanoárabe, más largas referencias a los autores orientales. La influencia que ha ejercido, sobre todo en el norte de África, se comprueba con la serie de citas y de resúmenes que allí se han hecho, hasta los últimos tiempos"13.

Habrá que llegar hasta el granadino In Hudayl, como asimismo afirma C. Álvarez de Morales $^{14}$, para encontrarnos con una obra de hipiatría, de cuya parte cuarta precisamente nuestro tratado ha tomado también parte de sus recetas: dos recetas de carácter mágico para curar a la bestia ${ }^{15}$ y la descripción y uso de ciertas plantas que por sus propiedades curativas sirven como medicamento para ciertos males propios del animal, tal es el caso de la alholva; o el empleo del clíster asimismo indicado para determinados casos. C. Álvarez de Morales ${ }^{16}$ describe esta parte como sigue: "La Parte cuarta, con la que finaliza la obra, es la menos científica. Se extiende de los folios $113 \mathrm{v}$ al $144 \mathrm{r}$ y en ella se indica cómo practicar las sangrías, diversos procedimientos para hacer crecer el pelo caído por causa de quemaduras o heridas, modos de teñirlo, formas de endurecer el casco, utilización del cauterio, curación de quemaduras y heridas, uso de las lavativas, utilidad de diversas plantas concretas, manera de herrar, conocimiento de la edad del animal además de por los dientes, distintos tipos de piensos y, como curiosidad final, aplicación de fórmulas mágicas y exorcismos en la curación de las bestias" (fols. 132v-134r) ${ }^{17}$.

13. José María Millás VALlicrosA, «La tradición de la ciencia geopónica hispanoárabe», en Estudios sobre historia de la ciencia española, vol. II, Barcelona, 1960, p. 129.

14. Cf. obra citada en nota 12 y J. SAMSÓ, La ciencia de los antiguos en Al-Andalus, 1992 (cf. nota anterior, pp. 4311-431): "la etapa nazarí se caracteriza por un desarrollo notable en la literatura hipológica[...] la aparición de una serie de cinco tratados sobre hipología de los que sólo uno se ocupa de las enfermedades del caballo y de la manera de tratarlas[...] Tenemos pues aquí el único tratado de hipiatría o albeitería de la serie, conservado en un único manuscrito de la Real Academia de la Historia, y titulado al-Fawāid al-musattara fi-'ilm al-bayțara («Cosas útiles puestas por escrito sobre la ciencia de la albeitería»). Consiste en una exposición razonada de los tratamientos que requieren las enfermedades del caballo, en la que se pasa revista a las dolencias que se fijan en los órganos superiores del cuerpo del cuadrúpedo, las de las extremidades inferiores o patas, las que comúnmente afectan a varios órganos indistintamente, y las anormalidades que se observan en la práctica de la albeitería”. Asimismo en la p. 383 afirma: “[...] constituye, sin duda, el tratado andalusí de agricultura más completo que conocemos $[\ldots]$ ”.

15. Ibídem. Agradecemos a C. Álvarez que nos haya facilitado la copia del manuscrito (n. ${ }^{\circ}$ XLII de la Real Academia de la Historia) de donde hemos tomado estos antecedentes.

16. Ibídem (pp. 311-312)

17. Ibidem. 
Con todo, nuestro texto basa también gran parte de sus asertos en Hipócrates, autor asimismo muy citado por Ibn al-'Awwām, -a quien da el calificativo de "el Veterinario"-, autoridad igualmente mencionada, por otra parte, en las versiones arábigas de las obras geopónicas griegas juntamente con Erasístrato, Plutarco, Serapion y Asclepio ${ }^{18}$.

Por lo que atañe a la tercera fuente mencionada, el Libro de la Almohada de Ibn Wāfid, ya observó también al respecto C. Álvarez de Morales en su estudio sobre el Tratado de Hipiatría de Ibn Hudayl ${ }^{19}$ cómo las dolencias del caballo se curan siguiendo el mismo método que aquél empleó en su Libro de la Almohada; prescindiendo, lógicamente, de las drogas y de sus cantidades, el sistema de estructuración del libro es el mismo: título de la receta en el que se indica contra qué dolencia está indicada y, a continuación, descripción de dogas, cantidades de las mismas y proceso de preparación del medicamento ${ }^{20}$.

Nuestro texto, como asimismo veremos, presenta sus recetas respecto al original del médico toledano de forma también incompleta y desordenada, como igual sucede con las otras fuentes árabes señaladas.

\section{CONFRONTACIÓN DE LAS FUENTES}

a) Libro de agricultura (II, XIV, 517)

"De lo que da a conocer la edad de las bestias...

Quando ha mudado sus quatro terceros dientes el karihón, lo qual es a los cinco años; cuyo nombre se dice (en singular), y kórrahon en plural; el de la hembra es kárihon y (el plural) kawarihon.

Fuera de lo que hemos expresado nada más muda de sus dientes, y llámase fárason (o caballo ya hecho), no por los años que tiene, sino por los dientes mudados [...]”.

\section{Tratado morisco}

"Cómo conocer la edad de las bestias (2):

Sabe, Dios te guarde, que toda bestia a los treinta meses muda un par de muelas de arriba y de abajo. Y, en el momento en que la bestia cumple tres años y medio, cambia dos de sus molares también, y entonces

18. M. ${ }^{\text {a }}$ C. VÁzQUez de Benito, El manuscrito $n^{\circ} X X X$ de la Colección Gayangos, Madrid, A. E. C., 1974.

19. C. Álvarez de Morales y RUIZ-MATAS, «La medicina árabe en el reino taifa de Toledo», Toledo Hispanoárabe, pp. 33-38.

20. Ibidem. 
es de cuatro muelas. Cuando el animal haya cumplido cuatro años y medio, es decir, es fresca e igualada $[\ldots]^{21}$.

Libro de agricultura (II, XVII, 527)

"Dice Aben Abí Hazám [...] que en una de las cosas que engorda y con que presto adquieren gruesa y extendida carne, es que cortando la mielga la seca en las menudas partes que sea posible y quebrantando la cebada, se ponga después un barreño vacío en el pesebre y otro con agua dulce, y tomando luego parte de aquella mielga se lave y se saque del agua para que no se acede, dexándola el espacio que media desde la madrugada hasta nacer el sol, que viene a ser dos horas o menos: que yendo después y tomando de aquella mielga remojada uno o dos puñados se eche en el barreño vacío, tomando luego y esparciendo la cebada quebrantada sobre aquella mielga, y mezclando ambas cosas juntamente en el barreño que está delante de la bestia”.

Tratado morisco

"Un aserto de Hipócrates (76):

Para que el animal engrose macera día y noche en agua para que se ablande beleño cortado en trozos y cebada. Coge después el agua, frótalo con ella y echa la cebada al pienso, porque el bruto adquirirá peso ¡Permítalo Dios!”.

Libro de agricultura (II, 570)

"Otro de Hipócrates el Veterinario para la mancha blanca y para las nubecillas y paño en los ojos:

Tómese armuelles y cinco granos de pimienta, cuyas dos cosas molerás bien y cernerás en cedazo de seda de clara textura, y poniendo de aquel (polvo) en una caña taladrada lo soplarás en el ojo de la bestia; pues repitiendo esto algunas veces, le sea (mediante Dios) provechoso y útil”".

\section{Tratado morisco}

"Sobre la mancha blanca en los ojos de la bestia (89):

Tritura semillas de armuelle con cinco granos de pimienta. Espolvorea el producto resultante en los ojos de la bestia. Es cosa probada".

Libro de agricultura (II, 679)

"La uña que aparece en el ojo de la bestia, y es una cosa añadida a su túnica a manera de película, y que nace en los ángulos interiores del ojo, próximos a la nariz [...] su remedio dice Aben Abí Hazám, es que, cogiendo a un tiempo el ojo por los dos lados que están próximos a los ángulos, y haciendo que cuelgue la uña, cortes ésta con herramienta afi-

21. Cf. nota de la traducción. 
lada semejante a una lanzeta chata [...] y que así que hayas cortado aquella película, se lave el ojo blandamente con agua y vinagre, y se tenga ligado tres días [...] si la bestia tuviere la uña incorporada con el círculo exterior adiposo [...] se abrirá con la herramienta y se removerá de dicho círculo y después de esto se cortará. En seguida se lavará la parte con vinagre o agua tibia, y se tendrá el ojo con un trapo suave tres días, y después se curará con este medicamento: tómese una onza de la climia (escoria) de oro, dos onzas de la de la plata y de raíces de azucena, y otro tanto de buena miel, y mezclando con ella los simples bien molidos y cernidos úntese con ello la parte algunas veces, pues es útil y provechoso".

\section{Tratado morisco}

"Sobre la uña que se forma en los ojos de la bestia (22):

Abre los ojos del animal, introduce en ellos una aguja de hierro a fin de arrastrar con ella suavemente la uña hasta el borde del párpado y después la sajas. Pon a continuación salgema molida en los ojos".

"Sobre la uña en el animal (45):

Cuando el animal es afectado por la uña en sus ojos que los cristianos llaman 'ungula', introduce en estos una aguja de hierro y arrastra la excrecencia hasta el borde. Espolvorea a continuación en ellos salgema, o sea alpedrés y nitro, molidos, porque el animal se cura. ¡Permítalo Dios!”.

Tratado de agricultura (II, 664)

"Otro de Hipócrates el Veterinario en la operación de la carúncula sin fuego:

Toma unos cogollos de ramas de olivo con su hoja, y quemados cierne su ceniza y rapando y untando después el sitio de la carúncula con algún aceite, ponle luego encima, según su tamaño, un molde de heno seco o de madera en forma de anillo en el que se haya puesto aquella ceniza, y atándoselo bien de suerte que no se aparte de aquel sitio, déxalo así una noche; pues secándole esto la raíz, quedará sano el bruto el resto de su vida, mediante Dios".

\section{Tratado morisco}

"Sobre cómo tratar la carúncula o machacho sin fuego (26):

Toma hojas de olivo, quémalas bien, retira la ceniza y rasura la zona objeto de tratamiento a navaja. A continuación aplica sobre ella aceite de oliva y la ceniza resultante, atándolo por encima, porque saldrá de raíz ¡Permítalo Dios!”.

b) Tratado de hipiatría (fol. 132v)

"Entre los procedimientos curativos mágicos existentes hay uno para la despeadura: Cuando se presente ante tí el dueño de la bestia, que diga 
su nombre o el nombre de quien le acompaña. Cuando lo pronuncie, invoca el nombre de Dios diciendo: ¡Juro por Dios que una despeadura han enviado los cielos que afecta a la pezuña del animal de fulano! Yo haré ensalmo y Dios curará. Coge a continuación uno de los pelos de la bestia y haz el hechizo otra vez con él diciendo las mismas palabras tres veces. Haz de nuevo tres nudos en el pelo, repitiendo tras cada nudo lo mismo. Ata seguidamente el pelo anudado y ensalmado en la pata del animal, porque se cura. ¡Permítalo Dios!”.

\section{Tratado morisco}

"Sobre la despeadura que en romance se dice "calambre"22 (4):

Cuando se presente ante tí el animal despeado en compañía de su dueño, pregunta a éste su nombre y el nombre de su madre. Cuando haya respondido, invoca el nombre de Dios diciendo: ¡Juro por Dios que los cielos han enviado una despeadura que aqueja a la pezuña del animal de fulano hijo de fulano! Yo haré ensalmo y Dios curará. Coge a continuación un pelo de la bestia y vuelve a hacer el hechizo pronunciando las mismas palabras, mas haciendo a la vez dos nudos con aquél y repitiendo lo mismo al final de cada uno. Ata seguidamente el pelo ensalmado y anudado en la pata del animal diciendo $[\ldots]^{\prime 23}$.

\section{Tratado de hipiatría (fol. 129v)}

"Medicamentos que secan las heridas húmedas y las cicatrizan:

Se coge incienso, sangre de dragón, mirra áloe y sarcocola. Se tritura todo, se espolvorea el producto resultante sobre la herida y, si no sobrevienen punzadas, ésta se cura [...]”.

\section{Tratado morisco}

"Sobre cómo cerrar las heridas con hilo (95):

Coge al šayān, que en romance se llama 'sangre de dragón', e incienso. Haz unos polvos y échalos sobre la herida y cósela, porque cerrará y curará. ¡Permítalo Dios!”.

Tratado de hipiatría (fol. 129r)

"Sábete que la alholva resulta beneficiosa para todo mal interno que afecta al animal en sus vísceras, a la vez que evita su corrosión, la sequedad de las heces y la retención de los gases: toma un almud de alholva, muélela bien, ponla en un recipiente y añádele agua en una cantidad que la cubra. Hiérvela seguidamente a fuego suave, y cuando veas que está en su punto, añade un arrate de manteca de vaca de-

22. El término romance no coincide en este caso con la significación del vocablo árabe.

23. Texto corrupto. 
rretida, tres onzas de aceite de almendra, una onza de aceite de nuez y otra de óleo de rosa. Introduce el producto resultante en la garganta del animal durante tres días seguidos, porque no existe otro medicamento como éste para curar los males internos de la bestia. ¡Quiéralo Dios!”.

\section{Tratado morisco}

"Sobre los beneficios que la alholva reporta a las bestias (75): Hipócrates afirma que la alholva resulta beneficiosa para los males internos del animal, para el estómago, para el intestino y para la corrosión, a la vez que evita también la sequedad de las heces y la retención de los gases.

La fórmula de preparación es: cuécela bien, añádele un arrate de manteca de vaca derretida o de aceite de almendra y una onza de aceite y de óleo de rosa. Da a tomar el producto resultante durante tres días, porque con ello será suficiente para que se produzcan los beneficios indicados. ¡Permítalo Dios!”.

Tratado de hipiatría (fol. 133r.)

"Otro procedimiento mágico:

Dices: una burra ha entrado en tu casa y ha querido que la despeadura le sobrevenga.

Luego coges (pelos) del rabo de animal, los unes y haces con ellos siete nudos. A continuación los atas ya a la mano ya al pie de la bestia que se ha despeado, levantando con cuidado el casco, porque se curará. ¡Quiéralo Dios!”.

Tratado morisco

"Otro procedimiento (14):

Utiliza magia con el animal diciendo: un fuerte calor ${ }^{24}$ ha penetrado en Belén y lo ha querido afectar la despeadura. Coge seguidamente siete pelos del rabo, únelos, haz en ellos siete nudos y átaselos, porque obtendrás buenos resultados. ¡Quiéralo Dios!”.

\section{c) Libro de la almohada}

"Para la caída del pelo es útil aceite de mirto. Ésta es su receta: se toman hojas de mirto verde, en cantidad de tres ugiyyas, se trituran y se les añade un raṭl de aceite de oliva. Se expone al sol durante tres semanas y luego se usa. ¡Si Dios quiere!”.

\section{Tratado morisco}

"Sobre el nacimiento del pelo (83):

24. Se trata de un error de transmisión por parte del copista que ha leído hāarra en lugar de himāra. 
Si coges trigo y hojas de arrayán, es decir, murta, las trituras con óleo y aceite de oliva y aplicas en untura el producto resultante sobre la zona, el pelo aumentará y espesará". Libro de la almohada

"Receta de un remedio que seca las escrófulas y las cura [...] Se toma una serpiente, se le corta la cabeza y la cola, y se quema el resto del animal. Se cogen sus cenizas y se les añade una cantidad igual de electuarios o de confitura de rosa, que contenga un poco de canela. De este preparado se toman cada día cuatro o más dirhames, aumentando la dosis en días sucesivos hasta llegar a dos uqiyyas o más".

\section{Tratado morisco}

"Sobre las escrófulas (68):

Coge una culebra, corta la cabeza y la cola, ábrela por el vientre y aplícala sobre la zona afectada, porque los gusanos saldrán adheridos a ella".

En suma, a la vista de lo expuesto se confirma por un lado lo ya dicho por Dubler, que "esta espléndida ciencia islámica de al-Andalus cuya tradicional pujanza por vía oral se conserva aún hoy en el norte de África, degeneró entre los moriscos hispanos en un burdo saber casero, el cual se adivina por unas cuantas recetas en árabe y aljamiado" ${ }^{25}$. Y, por otro, las afirmaciones también de García Ballester cuando manifiesta que "una constante en los escasos fragmentos de la literatura terapéutica morisca conservada es el gusto por la polifarmacia. Gusto que, por lo demás, en nada se diferencia del sentido por la sociedad cristiana contemporánea. Las recetas conservadas en esa curiosa mezcla de árabe y aljamiado -clara expresión de una lengua científica residual- son muy expresivas" ${ }^{26}$. "No es de extrañar esta vinculación del médico morisco con formas de la medicina islámica [...] porque -en sus procedimientos curativos- coexisten no sólo restos de esquemas ancestrales, sino también de derivaciones y subproductos de una medicina propia perfectamente integrada en su cultura Islámica, en su nivel científico [...]"27. "El proceso de desintegración de la cultura islámica y la creciente marginación social de la masa musulmana y morisca, hizo que la medicina por éstos practicada fuera acentuando las prácticas empíricas y creenciales [...] y disgregándose la propia figura del profesional -que de por sí ya gozaba de la indefinición profesional característica de la cultura médica judeoárabe-. Para dar paso a un

25. C. E. DUBLER, La materia médica de Dioscórides, Barcelona, 1953, vol. I, p. 57.

26. L. GARCÍA BALLESTER, Los moriscos y la medicina. Un capitulo de la medicina y la ciencia marginadas en la España del siglo XVI, Barcelona, 1984, pp. 88 y 89.

27. L. GARCÍA BALLESTER, Medicina, ciencia y Minorías marginadas: Los moriscos, Granada, 1976, p. 144. 
florido y pintoresco mundo de 'curanderos' que, por otra parte, hubieran existido igual de haberse mantenido la medicina científica y profesional" 28 .

\section{LOS PROCEDIMIENTOS CURATIVOS}

1. Las substancias más utilizadas por nuestro texto en la elaboración de los remedios y por este orden son: el aceite de oliva, el vinagre, el agua, la miel, el trigo, la grasa de cerdo, los higos, la sal, el arrayán o murta, la almáciga, el azogue, la cáscara de huevo, la cebolla, el coriandro, el incienso, las lentejas, el laurel, la manteca de vaca, la nuez, la sangre de dragón y la culebra, por lo que atañe a la medicina.

Las formas de tratamiento son las siguientes:

- Bisturí: para extirpar verrugas y vejigas.

- Cauterización: para la lepra y las heridas.

- Colirio: para todo mal en los ojos.

- Emplastos: para heridas, escrófulas, testículos inflamados, tumores duros, extracción de huesos y astillas, inflamación de venas, vejigas, nervios inflamados, abrir heridas y para mordeduras.

- Insuflaciones: para vaciamiento de los humores del cerebro, cortar la hemorragia nasal, extraer las sanguijuelas de la garganta y para la lepra.

- Lavados: para hemorroides, prúrigo anal, la sarna y las fístulas.

- Pociones: para el vómito, diarrea, hernia, lepra, disuria y lombrices.

- Polvos: para el cerebro, contusiones, cicatrización de heridas, fístulas, verrugas y heridas.

- Sahumerio: para extraer sanguijuelas.

- Sangría: para dolores de cabeza y todo mal en la parte superior del cuerpo: inflamación de boca, obstrucción, sofoco, ahogo, etc.

- Unturas y óleos: para verrugas, lepra, inflamación de párpados, crecimiento del pelo, sarna, enrojecimiento de ojos, hemorroides, heridas, extracción de dientes, picaduras o mordeduras de animales, grietas en los talones, inflamaciones, úlceras infectadas y piernas inflamadas.

2. La aplicación específica de los medicamentos es como sigue:

- Albarazo: cantáridas (abdómenes), lentejas (harina), liebre (sangre), miel, rosa (óleo), rubia, sal, serpiente, vencejos, vinagre. 
- Cefalea: asafétida, incienso, jugo de cáñamo.

- Contusiones: ciervo (cuerno), cobre (láminas), gallocresta, trigo, zapato (piel).

- Diarrea: apio, arrayán, cepa de vid, enebro, menta.

- Disuria: agua, aceite de oliva, cáscaras de huevo, lentisco.

- Dolor en los ojos: asafétida, incienso.

- Enrojecimiento de ojos: leche de mujer, litargirio.

- Espina (mal en el pulgar): azogue, cardenillo, miel, parietaria, rejalgar, vinagre.

- Escrófulas: cebolla blanca, culebra.

- Extracción de astillas, espinas y huesos: manteca de vaca.

- Extracción de dientes: albayalde, coloquíntida, vinagre.

- Extracción de feto muerto: hormigas, paja de cebada.

- Extracción de gusanos: cebolla, culebra, melocotonero (hojas).

- Extracción de verrugas: aceite, agua, adelfa, arsénico, euforbio, miel, sarcocola, sarmiento, trigo (harina), vinagre.

- Extracción de sanguijuelas: carnero (piel), chinches.

- Fístula: cebada (harina), miel.

- Grietas: aceite de oliva, brea, pez.

- Heridas con gusanos: cebolla, melocotonero (hojas).

- Heridas (cicatrización): aceite de oliva, agalla, almáciga, incienso, sangre de dragón, tierra de Sevilla, vinagre.

- Heridas (abrir): marrubio, miel.

- Hernia: almáciga, almidón, cuajaleche, mastuerzo, nuez.

- Hemorragia de las heridas: agua, aceite de oliva, agalla, almáciga, estoraque, vinagre.

- Hemorragia nasal: alquitrán, brea, cáscara de huevo, gusanos, pluma de ave, resina, zumaque.

- Hemorroides y prúrigo: agua, aceite de oliva, ceniza, lana sucia, peral (raíces).

- Inflamaciones de heridas: aceite de oliva, cebolla blanca, cobre (lámina), cola de caballo, comino, óleo de rosa, vino, vísceras de pollo.

- Inflamación de hombros: alcachofa blanca.

- Inflamación dolorosa: aceite, lana, vinagre.

- Inflamación en nervio: grasa de cerdo, higos.

- Inflamación en párpados: miel, sal, vinagre.

- Inflamación en piernas: azogue, grasa de cerdo. 
- Inflamación por sangría: aceite de oliva, esponja de mar, lana, óleo de rosa, vinagre.

- Inflamación de testículos: acelgas, miel.

- Lepra: camomila, cantáridas (abdómenes), helecho, lentejas (harina), liebre (sangre), llantén (hojas), manteca de vaca, miel, rubia, sangre de dragón, serpiente, vinagre.

- Lombrices: ajos calcinados.

- Mal en los ojos: azúcar de Salomón, cardenillo, escoria de bujía, granada.

- Pelo (crecimiento): aceite de oliva, arrayán (hojas), dátiles (huesos), óleo de rosa, nuez, trigo.

- Picaduras de animales: levadura de la masa del trigo, vinagre.

- Sanguijuelas: habas.

- Sarna: aceite de oliva, adelfa, agua, apio, azufre, brea, cerraja, coriandro, espino albar, grasa, laurel (granos), litargirio, pez, ruibarbo.

- Pus (supuración): lirio (raíces), miel.

- Tumor duro: higos lambadar, hinojo, jabón, rábano, tela de araña.

- Úlceras infectadas: laurel, parietaria.

- Varices: alcachofa blanca.

- Vómito y diarrea: almáciga, arrayán, coriandro, menta, vid (zarcillo).

3. Son pues las substancias de origen vegetal las más empleadas tanto en medicina como en veterinaria, seguidas de las de origen animal y mineral ${ }^{29}$. Así:

a) Substancias de origen vegetal:

- Aceites: de almendra amarga y dulce, lino, nuez, oliva, onfacino, rosa.

- Acíbar socotrino, aceituna, adelfa, agalla, alheña, alholva, ajenjo, ajonjolí, ajos, almendras, anacardia, apio, armuelle.

- Berenjena, beleño, bledo.

29. L. GARCÍA BALLESTER, Los moriscos y la medicina..., p. 82: “[...] sobre este conglomerado de esquemas médico científicos y creencias, se mantenía vivo un rico mundo de conocimientos terapéuticos centrados, sobre todo, en la materia vegetal. En todos los médicos moriscos es éste el aspecto de su medicina que más destaca. Llama la atención, no sólo la amplitud de 'yerbas' que manejan sino la complejidad y barroquismo de sus recetas, muchos de cuyos excipientes e ingredientes eran adquiridos en las boticas"; p. 131: "La medicina mágica que domina el universo terapéutico de los sanadores moriscos utiliza una materia médica enormemente amplia, que recurre a los tres reinos de la naturaleza: vegetal, animal y mineral, con especial predominio del vegetal. Este se beneficiaba no sólo de su mayor y más amplio conocimiento empírico, apoyado además en una rica tradición islámica propia”. 
- Casia, casiafistula, calabaza albarrana, camomila, cebada, cebolla, albarrana, blanca y roja, centeno, col, cola de caballo, coliflor, doncella. - Estafisagria, estopa, euforbio.

- Granada, greda blanca.

- Habas rojas, hinojo.

- Incienso.

- Laurel, levadura de trigo, lino, llantén.

- Malvavisco, melón, mirto, morela.

- Olivo, olmo (raíces).

- Pan, parietaria, pimienta, poleo.

- Raíces (hinojo, olmo, torvisco).

- Regaliz, retama.

- Salvado, sesbán.

- Semillas (col, hinojo, lino, melón).

- Tamarisco, torvisco, tragacanto, trementina, trigo.

- Vinagre, vino.

b) Substancias de origen animal:

- Camaleón (excremento), caracol, cerdo (carne salada, corteza), culebra (hiel).

- Excremento humano y de lagarto.

- Gallina, grasas (de carnero, cerdo, manteca de vaca), gusanos.

- Huevos.

- Jibión.

- Lana, leche (de asna, de cabra).

- Piel (de zapato).

- Vísceras de pollo.

c) Substancias de origen mineral:

- Agua, albayalde, almartaga, arsénico, azufre.

- Brea.

- Cal, cardenillo, cobre (limaduras).

- Estopa.

- Hollín.

- Lejía.

- Nitro.

- Oropimenta.

- Pez. 
- Sal.

- Salgema.

- Vidrio.

4. En cuanto a Veterinaria, los procedimientos curativos más comunes son: Cauterización, clíster, ingesta, sahumerio, sangría, untura, vaporización, sajadura con bisturí y procedimientos mágicos, como hemos señalado ${ }^{30}$.

Las substancias utilizadas son las siguientes:

- Adivas: aceite, azufre.

- Ajuagas: acíbar, albayalde, alheña, almartaca, azufre, berenjena (cáscara), brea, cardenillo, euforbio, grasa de carnero, malva, salvado, vinagre.

- Asma y ahogo: levadura, pan de centeno.

- Caída de las cerdas del copete: calabaza, albarrana, leche de cabra, manteca de vaca, raíces de hinojo y de torvisco.

- Casco (males en): aceite de oliva, brea, grasa, incienso, limaduras de cobre, vidrio.

- Cicatrización de heridas: cortezas de cerdo y de queso.

- Contorsión: cebada, greda blanca.

- Chancro: harina de cebada, miel.

30. A. LABARTA: Libro de dichos maravillosos..., trata el tema de la magia de la palabra (o. 35-o. 36) diciendo: "[...] de modo general puede decirse que tratamos con una magia de tipo 'verbal', ya sea oral ya escrita. La oral se manifestará en recitaciones, invocaciones, conjuros, letanías. La escrita dará como resultado un objeto con unos caracteres portadores de una energía mágica, cuyo poder, a su vez, se podrá utilizar de distintas maneras: a) por contacto directo [...] b) metiéndolo en un canuto que se entierra u oculta $[\ldots]$ c) transferir la energía mágica a otro elemento [...] El texto con el que se ha confeccionado la fórmula mágica que luego sufre los distintos procesos puede consistir en alguno de los siguientes elementos o en varios de ellos combinados, dependiendo del fin al que se destina: Corán fawätih, repetición de fórmulas y letanías religiosas [...] invocaciones o alusiones a personajes legendarios islámicos [...] fórmulas en otras lenguas, nombres divinos y angélicos de la tradición hebrea, palabras o fórmulas en latín, fórmulas incomprensibles, cuadros mágicos, círculos, estrellas, letras con anteojos, escritura pseudocúfica". Asimismo, esta medicina mágica para el tratamiento de los caballos era utilizada ya por la hipiatría islámica, sobre la cual llamó la atención C. ÁLVAREZ de MORALES, en Los animales en los textos..., y también en el trabajo del mismo autor realizado en colaboración con F. GIRÓN, Mujtașar fî-l-tibb (Compendio de Medicina) de Ibn Habīb, Madrid, 1992, p. 34: "El tercero y último, que va del fol. 39tr. al 45v., está del todo desligado del anterior [...] El tipo de medicina que encierra [...] es la 'mágica' o por seguir las palabras del manuscrito, la magia aplicada a la medicina, alternando el empleo de ensalmos e invocaciones religiosas con el uso de amuletos. Nuevamente lo calificamos de Medicina del Profeta". Y, en otra parte del trabajo, "la segunda de las noticias (f. 43v.) se refiere a cómo en una ocasión concreta, y con protagonistas también concretos, se consiguió volver dócil a un caballo que había enloquecido. Siglos más tarde el granadino Ibn Hudayl en su obra al-Fawäid al-musattara fī- $i l m$ albayt ara vuelve a reproducir la anécdota". 
- Dájaso: makma, masma, miel, raíces de olmo.

- Debilidad: habas rojas, cebada.

- Desolladura: aceite, mirto.

- Despeadura: albayalde, azufre, bledo, estafisagria, grasa de cerdo, habas, miel, óleo de lino.

- Engrosamiento: beleño, cebada.

- Enredamiento: tamarisco.

- Esquinancia: malva, salvado.

- Gabarro: oropimenta.

- Hematuria: excremento de hombre.

- Higo: Arzaquwahusti(?) (semillas).

- Inflamación de boca: aceite de oliva, ajenjo amargo, apio, brea, grasa de cerdo, harina de trigo, manteca de vaca, miel, morela, vino.

- Intestino (salida de): brea, sesbán, torvisco.

- Machacho o carúncula: aceite de oliva, cebolla albarrana, torvisco (hojas).

- Mancha blanca: anacardia, armuelle, cebolla albarrana, excremento de lagarto, estiércol de camaleón, granada, hiel de culebra, hinojo (semillas), jugo de llantén, leche de asna, pimienta, toronjil.

- Males internos (estómago e intestino): alholva.

- Muermo: aceite de oliva, col, gallina, huevos, vinagre.

- Pies de las ovejas (cavidad en): aceite, agalla, ajos, clara de huevo, pimienta, salgema, vino.

- Reticulación: brea, grasa, poleo, vino.

- Sobrehueso o masa: ajo, cebolla albarrana, pimienta, sal.

- Sofocación: albalyalde, alholva, ajonjolí, col, grasa de cerdo, hinojo, huevos, vino, malvavisco, manteca de vaca, melón, miel, vinagre, vino.

- Sarna: aceite de oliva, ajo, alheña, calabaza albarrana, cebolla albarrana.

- Sentadura: agua caliente, euforbio, miel.

- Torzón: agua, vísceras de pollo.

- Vejigas: cebolla blanca o roja, lana, sal.

- Viruela: aceite de oliva, de laurel y de almendra, arsénico, cal, cardenillo, cebolla albarrana, hollín, lejía, limaduras de cobre, miel, tríaca.

Por tanto las substancias más usadas y por el siguiente orden son: aceite de oliva, cebolla albarrana, grasa de distintos animales, cebada, miel y vino. 


\section{COMENTARIO FILOLÓGICO}

Entre los rasgos más sobresalientes del texto se puede destacar que las alteraciones vocálicas que en él aparecen, referidas a la pronunciación clásica, son numerosas en cuanto a alargamiento, abreviación, cambio, su presión o aparición de vocales. En efecto, se introducen alargamientos o acortamientos sin ajustarse a un criterio uniforme, algún caso de imäla, y se escribe sukūn al final de muchos términos ya sean nominales o verbales. Asimismo se pone tašd $\bar{I} d$ arbitrariamente, generalmente sobre $m \bar{d} m$ a comienzo de palabra e igualmente sobre wāw o lam, a la vez que se coloca sobre la vocal. Alif suele ir vocalizada y marcada con hamza cuando ésta no debería expresarse, y al contrario. No se expresa hamza cuando sí sería adecuada su expresión. La tā marb üta frecuentemente se escribe (h) en lugar de (t). Son abundantes también las palabras que se parten al final de la línea, o que se escriben también con las vocales entre el cuerpo de las letras y sus correspondientes puntos diacríticos, e igualmente fatha entre la letra y el tašd $\bar{i} d$.

a) Es frecuente también hallar faltas de ortografía o intercambios. Así:

$B \bar{a}$ por $n \bar{u} n\left(q a^{\prime} r \bar{i} b\right)$ hendidura.

$T \bar{a}$ por $T \bar{a}$ (ayl $\bar{u} l a)$ gabarro; (mitrā̄d) zapatero.

Tā por ța (qanūt) canuto; (mastaka) almáciga.

$T a \bar{a}$ por $d \bar{a} \bar{d}(\hat{y} a r a \bar{t})$ jarado, tumor en el corbejón de la bestia.

Tā por $y \bar{a}$ (banat) ciñe.

$H \bar{a}$ por $\hat{y} \bar{m}$ (haratt) jarado, tumor en el corbejón.

Hia por hamza (haydarāiñ) sal gema.

Jā por gayn (däjisatayn) rótulas.

Däl por $r \bar{a}$ (dalzșS) empedradura; (dahqa) conducta.

$R \bar{a}$ por dă (rahsa) despeadura.

Zāy por dạl (aza) (zarajti) acederaque.

Sin por $z \overline{a y}$ (kasb ür) coriandro.

Sinn por șäd (rahsa) despeadura; (sabbät) zapato; (sawf) lana; (inŷās) ciruelo; (dalisa) empedradura; (mastaka) almáciga; (yasĩr) llegar a ser; (hasas) calvicie.

$\check{S} \overline{i n}$ por șäd (in ȳas) ciruelo.

Săd por $\sin$ (dajs) doradura; (ras') pata.

Däd por däl (hardūn) camaleón; (haydarān) sal gema.

Dāa por $z \bar{a}$ (tandamun) cicatrizará.

D.äd por sād ('adì $\bar{d} a$ ) gachas.

T.ā por $t \bar{a}($ rat $a m)$ retama. 
'Ayn por gayn (rass') pata.

Gayn por jā (dags) dájaso o clavo pasado.

Qäf por käf (qibrit) azufre; (qarabsi) apio; (qulä) riñones; (raqda) coz; (naqiyya) daño; (qaymūn) comino.

Qäf por gayn (maql) torzón.

Käf por qäf (salk) acelga; (kasbūr) coriandro; (Bukrāt) Hipócrates; (akhal) seca; (akhafat) descalabrarse.

Làm por $r \bar{a}$ ('ar'al) enebro.

Alif tawīla por alif maqșūra (jușā) cojones; (miqlä) sartén; (qulāa) freir; (tarā) veas; (hummā) fiebre.

Yä por hamza (käyin) existente; (gāyt) heces.

Yā por nún (haydarānì) sal gema.

Algunos casos de metátesis: Hịinaq por haqn, clister; junāqiya por ḥuqna, clister.

Finalmente, el demostrativo alterna su escritura en forma plena y abreviada, e igualmente la asimilación aratta con aradla y araddat.

En cuanto a la determinación, la marca que presenta el texto es la alternancia (al/ il), no acaeciendo la elisión de la vocal tras otra. El caso se utiliza mal. No se pone la marca (i) para el genitivo ni la marca (a) para el predicado de käna o para el acusativo.

Los sustantivos en dual conciertan con el plural o el plural de irracionales concierta con masculino o el femenino con el dual. Tampoco concierta el calificativo con el nombre.

La (n) de dual a veces no pierde la anexión.

Se confunde (in) condicional con (an) completivo.

El verbo a comienzo de frase y con sujeto explícito se pone en plural y además suele llevar prefijo (t). Por último, alterna la construcción de iḍafa con el uso de la preposición matā, matä' $a$ o $m \overline{1}$.

b) En cuanto al léxico, aparecen bastantes palabras romances ya como sinónimos del término árabe (38 vocablos), ya solos (24 vocablos), e incluso algunos mozarabismos (7). A saber:

ABIYŪ (karbas) apio (fol. 24v.).

ADİ̈BŠ (malä'in) adivas (fol. 11v.).

ANBĀDRADŪRAH (nuq ta) empedradura (fol. 23r.).

ANQAL (zafra) uña (fol. 15v.).

AŠBĪNŪ ALBĀR ( 'awsiy) espino albar (fol. 24v.).

AŠNŠIYŪ AMARGŪ (fasnatīn) ajenjo.

BALADRĪ (al-dafla) adelfa (fol. 21 r.). 
BARBAŠ (sulāq) barba (fol. 16v.).

BIYULAH (jubayz) viñuela, corazonera (fol. 4r.).

BURŪM (ațrūn) bromo (fol. 15v.).

DĀTILAŠ (tamar) dátiles (fol. 20v.).

DUNZĀLYU (fasnatīn) ajenjo, doncel.

FĀRUDURAH (dajas.) feridura, herida (fol. 3v.).

FINULĪ (näfi') hinojo (fol. 27v.).

FIŠTULAŠ (akkila) fístula (fol. 27v.).

GABAR (taylüla) gabarro (fol. 28r.).

IBALANTAYYIN (lisān al-ḥamal) llantén (fol. 13v.).

INRADĀMIDANTUH (hindiwān) enredamiento.

LĀ NA ŠUYAH (al-șawfal-muwadḍa') lana sucia (fol. 27v.).

LINTIŠQŪ (dar $\bar{u}$ sindarādìi) lentisco (fol. 21v.).

MANŶAŠ (akila) mancha (fol. 27r.).

MAŠAŠ (intišār) masa (fol. 14v., 20r.).

MIRLIYĀQARNĀRAH (jubayz) corazonera (fol. 14r.).

MIRULYĀQĀRA ( 'anab al-dib) hierma mora (yerba canina) (fol. 14r.).

MIRULYĀRQARAHA (jubayz) corazonera.

MURTAH ( $r$ ịhān) murta, arrayán, mirto.

MUWARMŪ (junāq $\bar{y} a)$ muermo.

QĀLAH $(\overline{a s} f)$ agalla.

QALAMRĀ (dahsa) calambre (fol. 2v.).

QULIBRĀ (hayya) culebra (fol. 21v.).

QULŪNTIDAH (janzal) coloquíntida (fol. 24r.).

QURTARSADŪRAH / QUNTURSIMĀNTUH ( 'iqqā) contorcimiento (fol. 3r., 18v.).

QUŶ̄UNUŠ (jușa) cojones (fol. 22v).

RABŪNTINUM (rand) rapónchigo (fol. 21v.).

ŠAL BĀDRUS (malh h haydar ānī) sal pedrés (fol. 15v.).

ŠANQUIRA DII IDRAQŪN (șayyān) sangre de drago (fol. 26v.).

ŠARNA ( $\hat{y} a r i ̉ b a)$ sarna.

ŠUBRIWĀ ̌̌ Ū (intišār) sobrehueso (fol. 14v., 20r.).

TURSŪN (magl) torzón (fol. 15v.).

URBĀMINTUH (zarnij) oropimente (fol. 28r.). 
Términos sólo romances:

ABLAN, llantén.

ALILARYU, lirio.

$\bar{A} M \bar{I}$ 1, almidón (fol. 12v.).

ANQAL, anca.

ARMŪ, muermo (fol. 17r.).

BAŠŠİQAŠ, vejigas (fol. 11r., 16r., 27v., 28r.).

DUNZĀLI, ajenjo, doncel.

FĀLAŶAH, helecho (fol. 14r.).

FIQŪŠ, higo (fol. 17v.).

FULIYAN, hollín.

IFRIŠQA, fresca (fol. 2r.).

IŠBIRBĀN, esparabán (fol. 28r.).

IŠBIYADA, despeada (fol. 28v.).

IŠQURŶA DĀBUŶIUA, escoria de bujía.

IŠQTUQDĀRĀN (?).

LUBADŪ, lobado (fol. 15v., 16r.).

MAŠAŠ machacho (fol. 11v., 12r., 29v.).

QAŠŠIFIŠTULAH, cañafístula (fol. 4r.).

QŪMA, goma.

ŠARBAWĀ ̌̌ $\bar{U}$, sobrehueso (fol. 18r.).

ŠĀNTADŪRAH, matadura (fol. 18r.).

TAYLAH (?), grano negro del trigo.

TIRMINTİNA, trementina.

TİRRAH SIBĪ LAH, tierra de Sevilla (fol. 30v.).

YLĀQW ĀLIDĀH, igualada.

Mozarabismos:

ASTUBBAH, estopa (fol. 11r.).

IMLĪQ, ombligo (fol. 9v.).

QANŪT, canuto (fol. 9v., 29v.).

RAŠI NAH, resina.

ȘABBĀT, zapato.

ŠARRĀLYA, cerraja (fol. 24v.).

ŠIŠBĪH, jibión, jibia (fol. 11r.). 
c) La transliteración por tanto en caracteres latinos es como sigue:

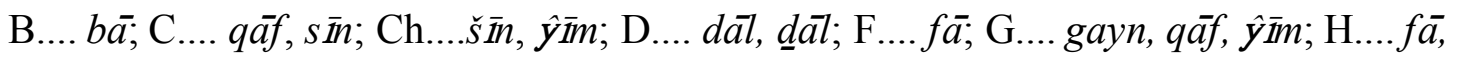

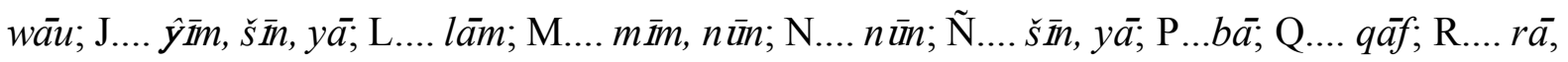
$\mathrm{S} . . . . \check{s} \bar{i} ; \mathrm{T} . . . t \bar{a}, t \bar{a}, \mathrm{~V} \ldots b \bar{a} ; \mathrm{Y} \ldots y \bar{a} ; \mathrm{Z} \ldots . . s \bar{i} n, z \bar{a} \bar{y}$.

Los grupos consonánticos en comienzo de palabra tienden a disolverse:

$\mathrm{BR}=$ buru, bar. $\mathrm{Dr}=$ idra. $\mathrm{FR}=$ ifri. $\mathrm{PL}=$ abla. $\mathrm{FL}=$ fala.

Vocalismo:

$\mathrm{A}=\mathrm{a}, \overline{\mathrm{a}}, \mathrm{i} . \mathrm{E}=\overline{\mathrm{a}}, \mathrm{i}, \overline{\mathrm{1}}, \mathrm{u} . \mathrm{I}=\bar{a}, i, \overline{1}, u . \mathrm{O}=\mathrm{u}, \overline{\mathrm{u}}, \overline{\mathrm{a}}, \mathrm{i} . \mathrm{U}=\mathrm{u}, \overline{\mathrm{u}}, \mathrm{a}$.

Diptongos:

$\mathrm{HUE}=$ wa. $\mathrm{MUE}=$ muwa. IA = iya, ŷah. $\mathrm{EA}=$ yā. $\mathrm{IO}=\mathrm{yu}$

El femenino se expresa (ah). El masculino (uh).

\section{LA EDICIÓN Y LA TRADUCCIÓN}

Hemos respetado el orden establecido en el manuscrito. Numeramos con cifras árabes cada receta siguiendo su orden tal como viene en el texto, numeración que indicamos a la derecha de cada epígrafe entre corchetes. Mantenemos todas las alteraciones que presenta el texto en cuanto a alargamiento, acortamiento, faltas de ortografía, intercambios, etc. Mantenemos también toda vocalización tal como aparece en el texto, con la excepción de que no escribimos las vocales entre el cuerpo de las letras y sus puntos diacríticos correspondientes. Hemos tratado de hacer una traducción lo más ajustada posible a la literalidad del texto. Cada nuevo epígrafe de la traducción, al igual que el texto árabe, está con cifras árabes y cuando la citemos pondremos siempre entre corchetes. Nos remitimos siempre a la foliación correspondiente, ya se trate del texto árabe, ya de su versión española. El aparato crítico es el usualmente utilizado. 
[fol. 1v. [كتاب فيه شرع معائي اليهطرة وأمرور ما يشاكل المعنى وفبه منافع كثيرة

$$
\text { ان شا ـ الله الموفت للحسراب. }
$$

$$
\begin{aligned}
& \text { 1- صفة دوا ، ليهيع أمراضى العين }
\end{aligned}
$$

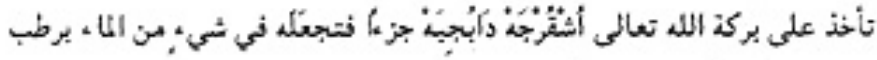

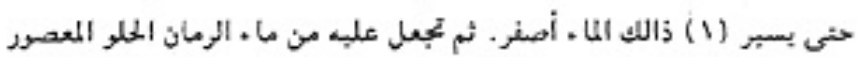

$$
\begin{aligned}
& \text { تدر ريع الماء. ثم تجعل عليه من الزيجار ومن السكر السليماتي لكل رطل من ذالك } \\
& 5
\end{aligned}
$$

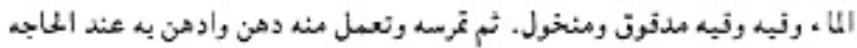

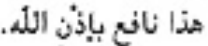

$$
\begin{aligned}
& \text { [fol. 2r.] }
\end{aligned}
$$

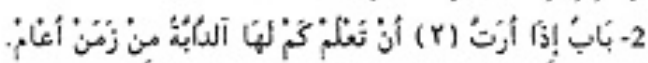

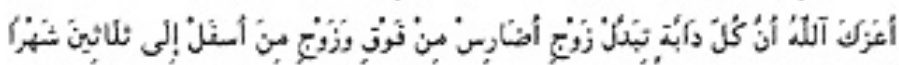

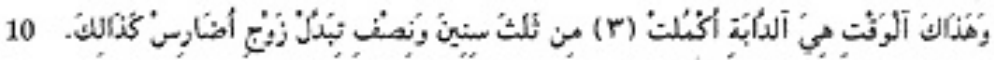

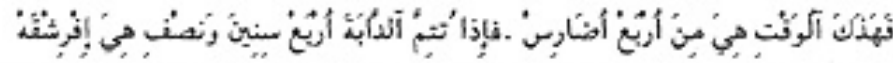

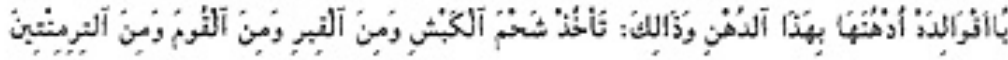

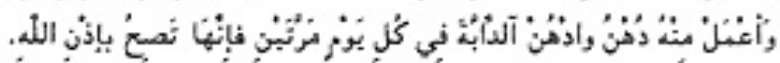

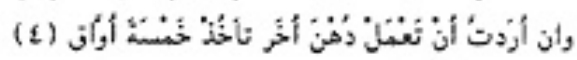

$$
\begin{aligned}
& \text { Léase is } \\
& \text { Léase } \\
& \text { Voz escrita al margen derecho, ir }
\end{aligned}
$$




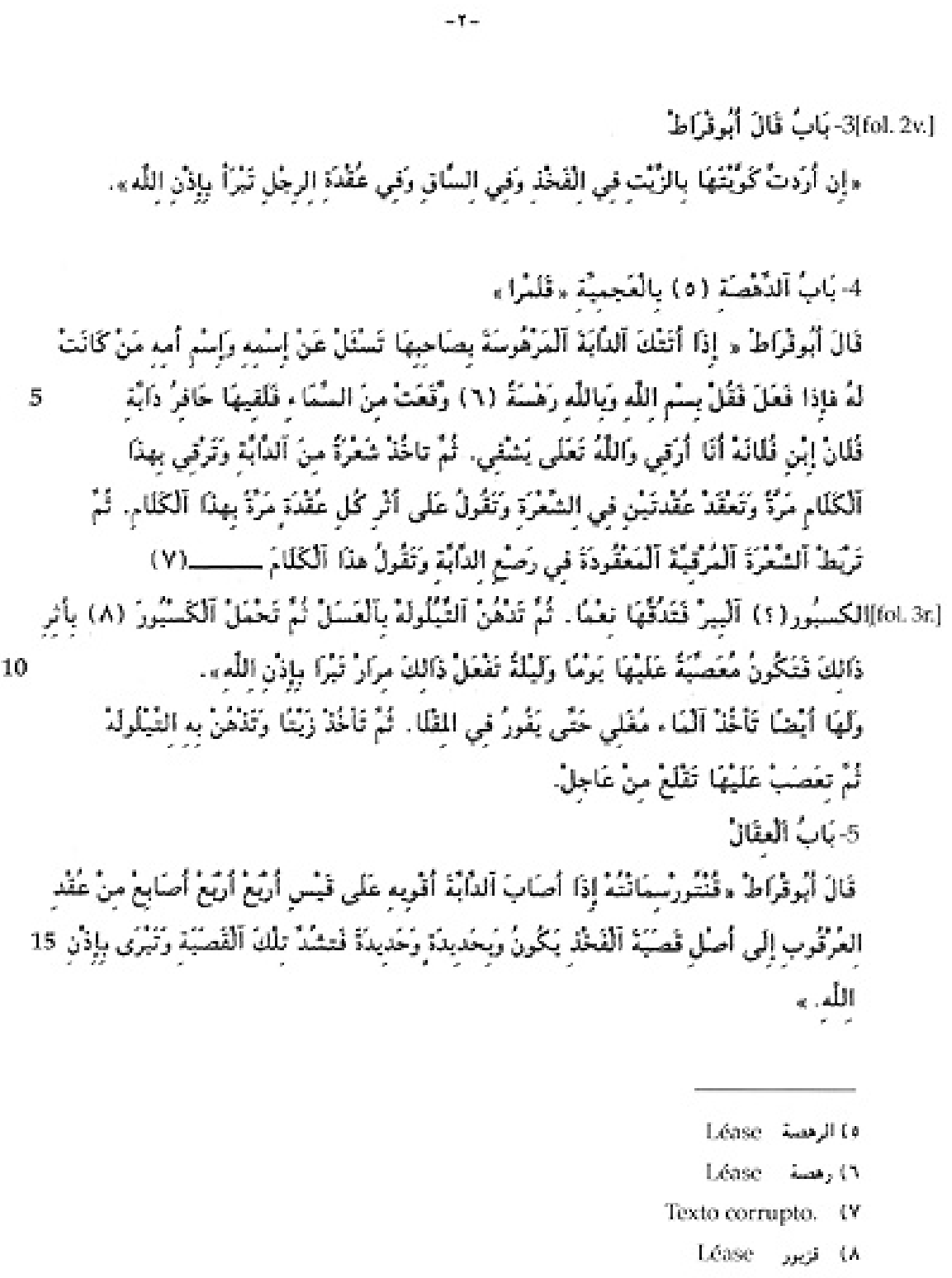




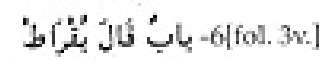

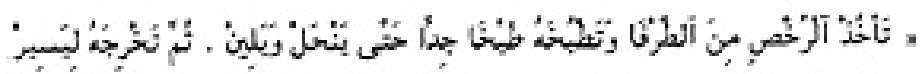

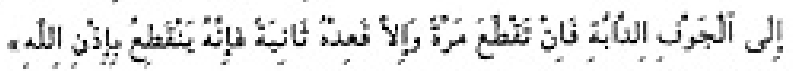

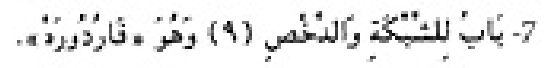

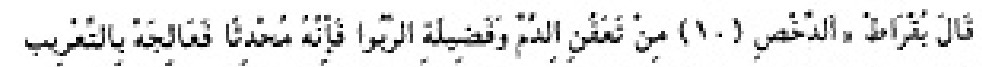

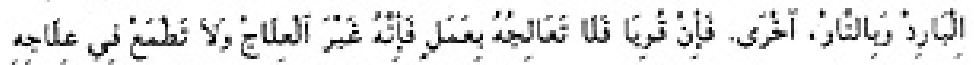

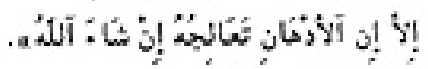

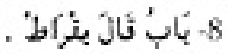

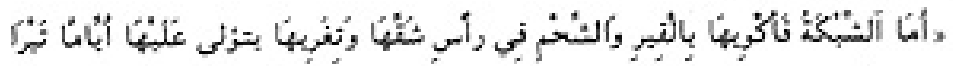

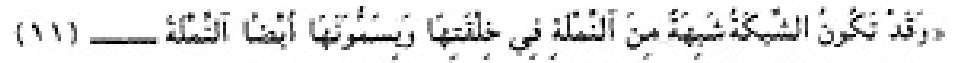

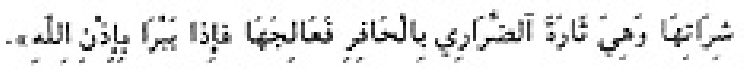

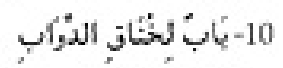

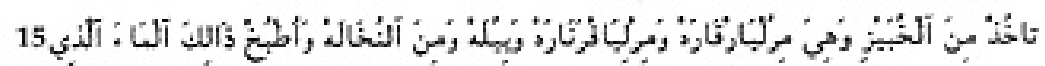

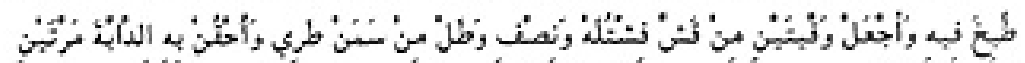

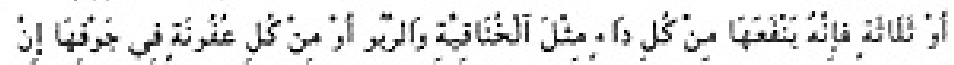

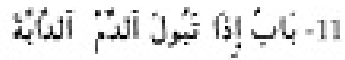

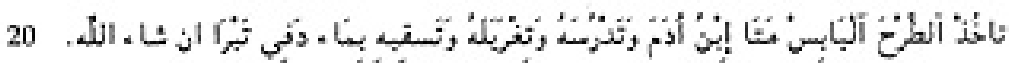

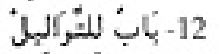

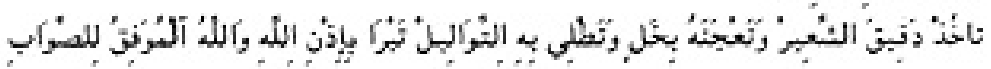




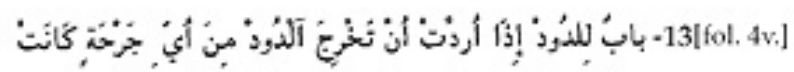

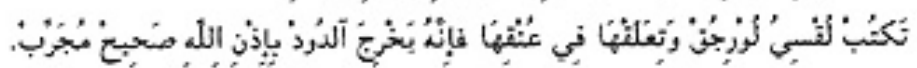

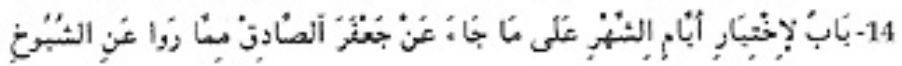

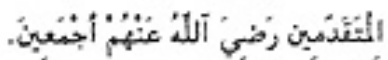

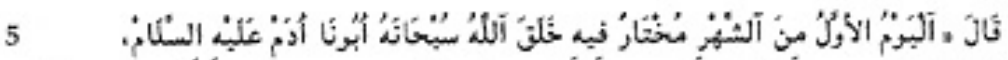

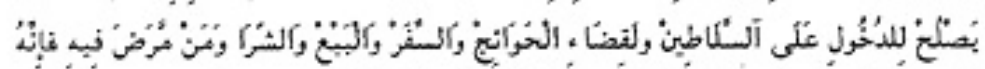

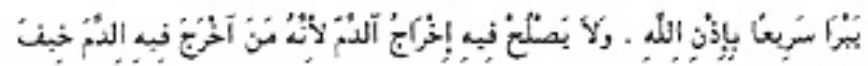

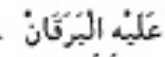

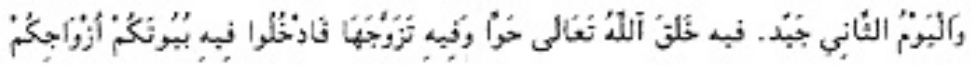

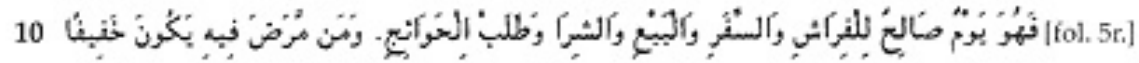

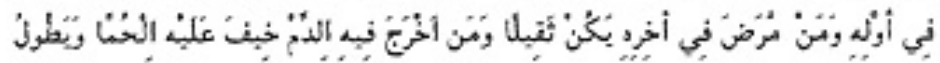

مرَّة.

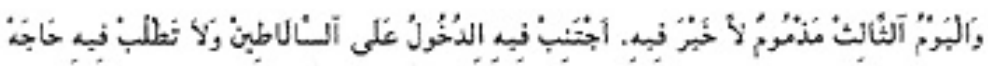

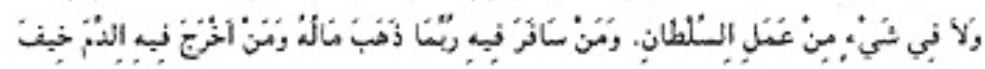

15

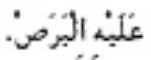

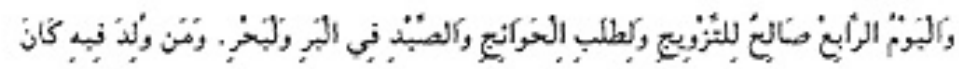

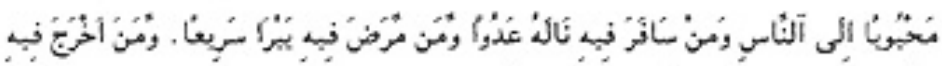

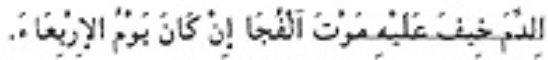

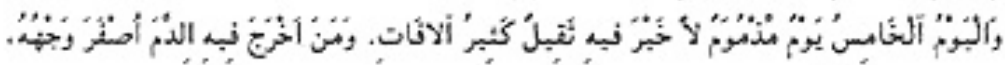

20

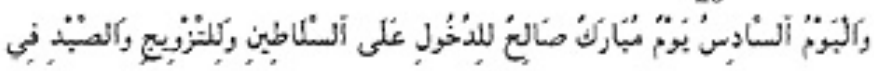




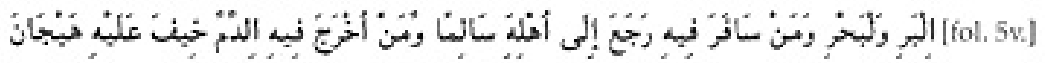

ألدم:

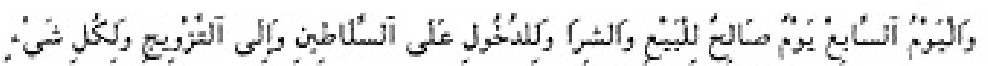

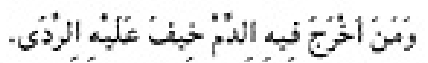

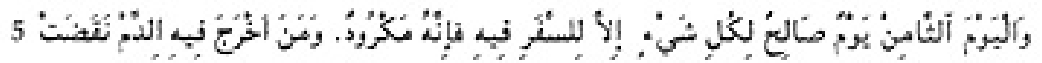

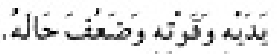

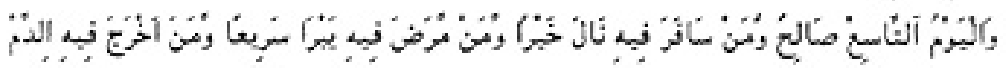

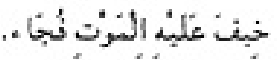

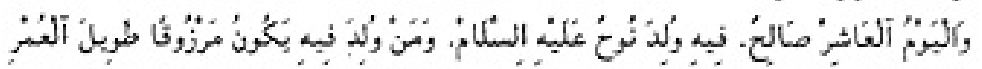

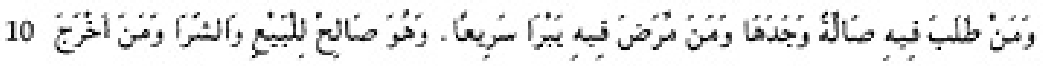

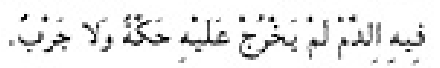

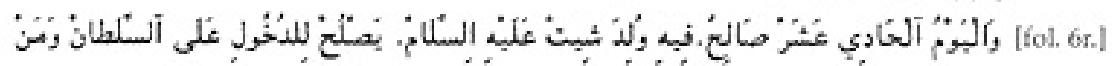

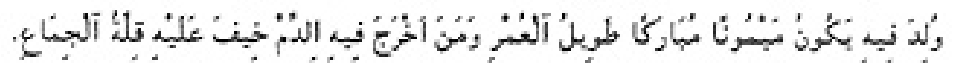

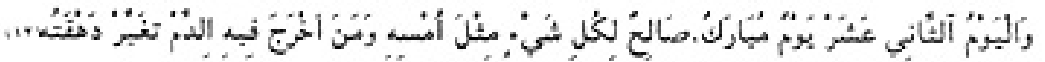

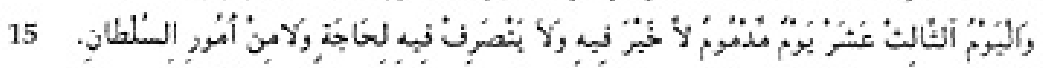

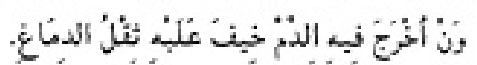

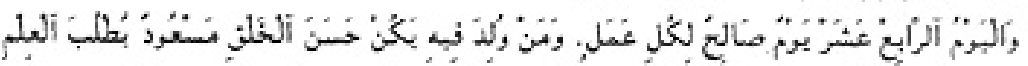

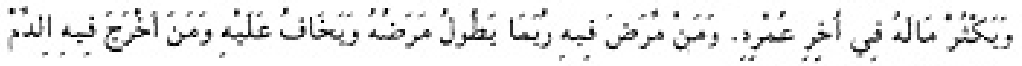

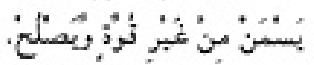

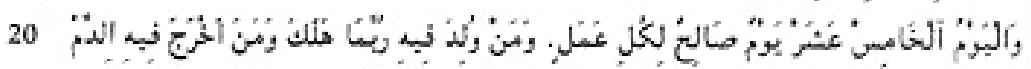




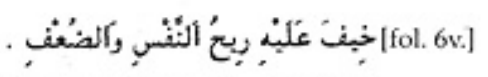

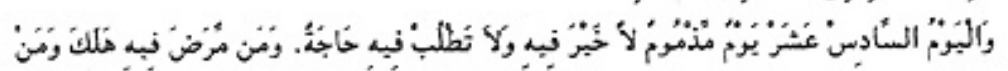

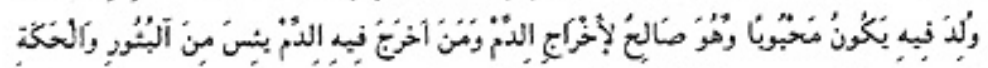

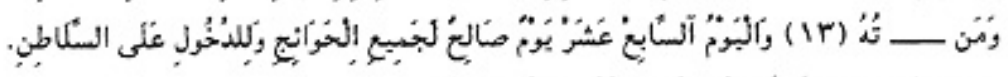

5

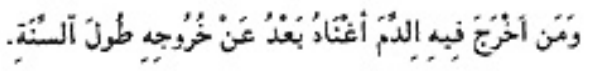

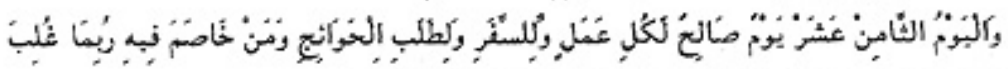

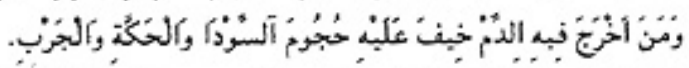

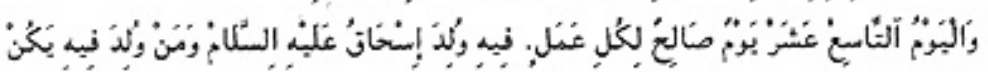

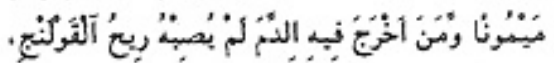

10

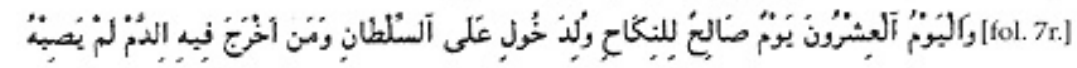

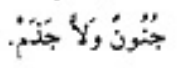

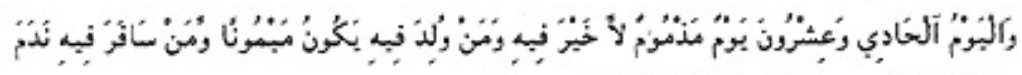

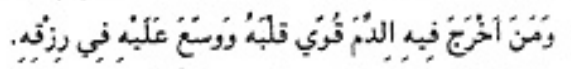

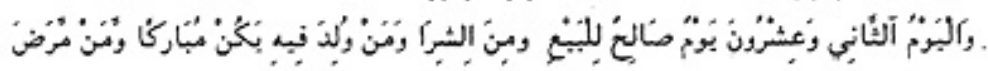

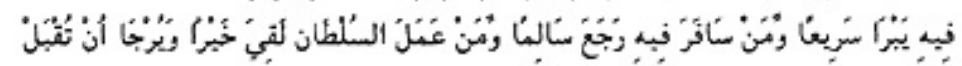

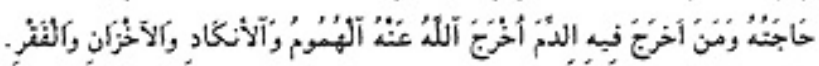

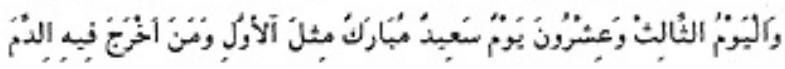




$$
\begin{aligned}
& -\mathrm{v}-
\end{aligned}
$$

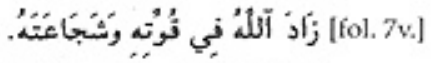

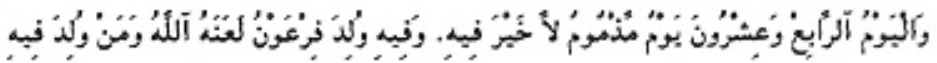

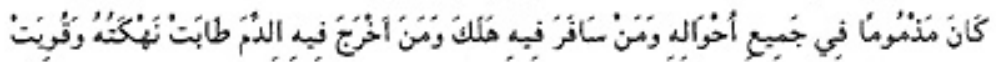

$$
\begin{aligned}
& \text { مَابتُشهُ. }
\end{aligned}
$$

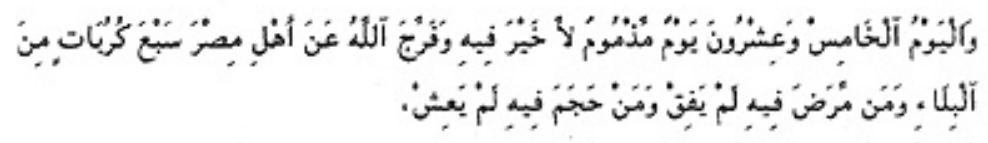

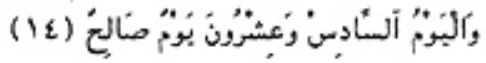

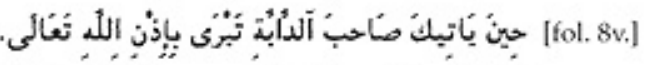

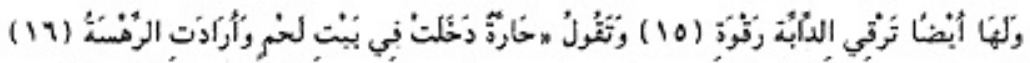

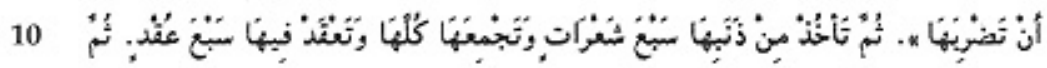

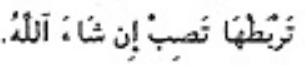

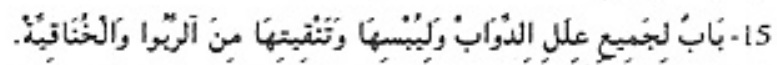

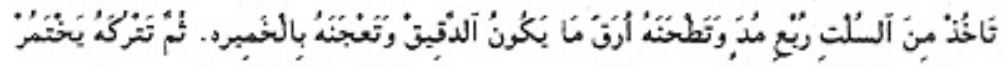

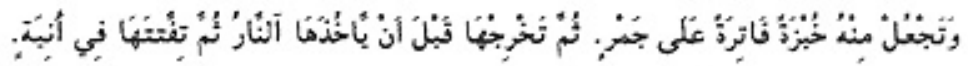

Texto corrupto. Las dos últimas líneas de esta página y toda la primera página del ( $(1 \leq$ fol. siguiente se hallan por completo borradas.

$$
\text { Voz escrita en el margen. (10 }
$$

Léase 


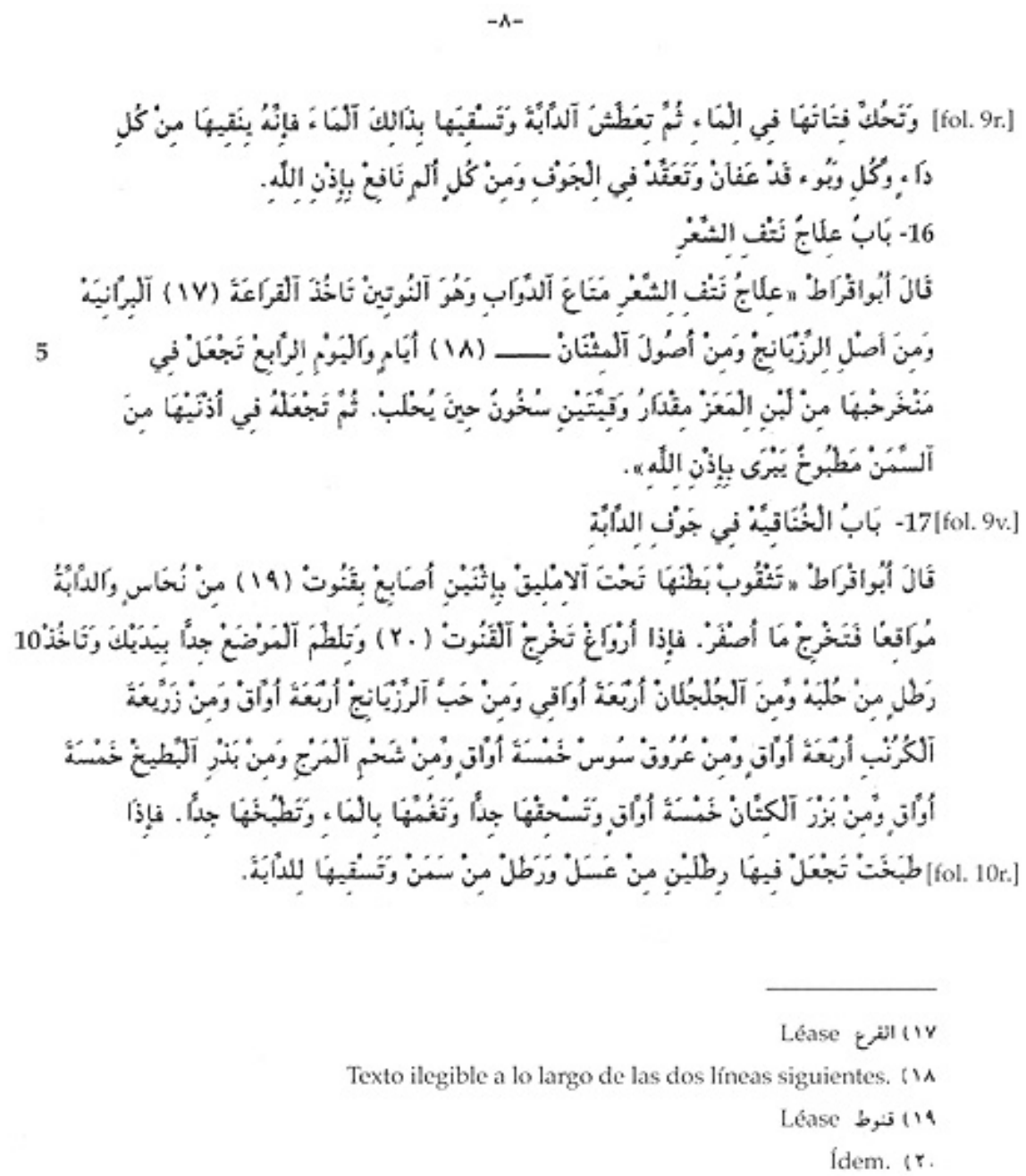




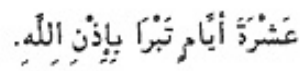

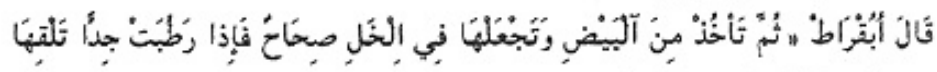

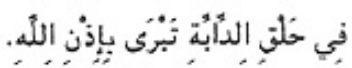

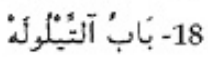

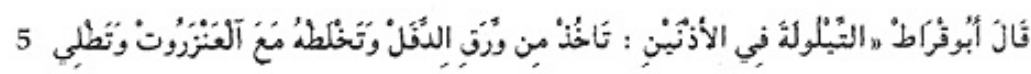

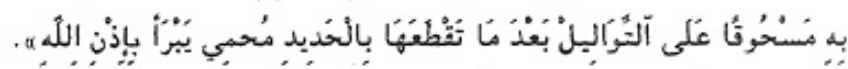

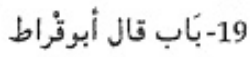

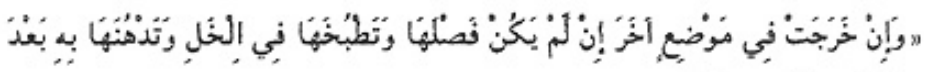

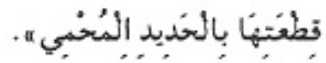

10

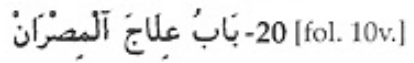

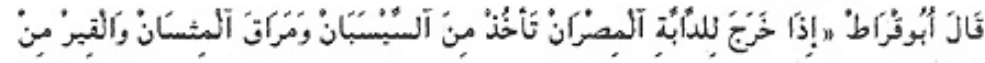

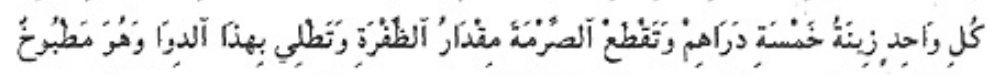

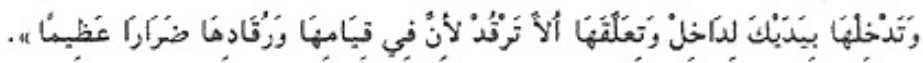

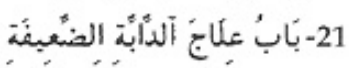

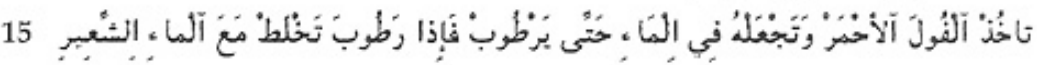

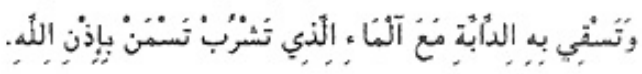




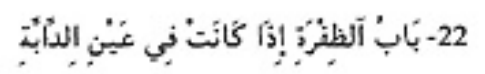

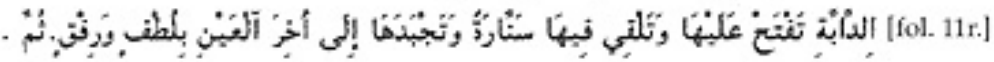

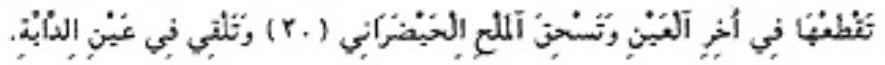

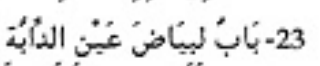

5

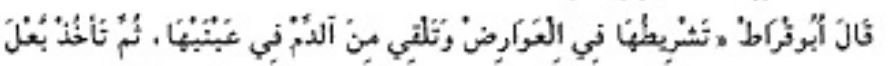

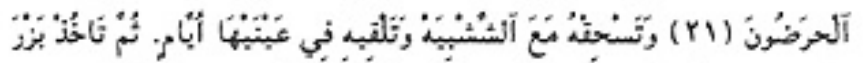

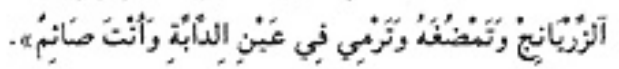

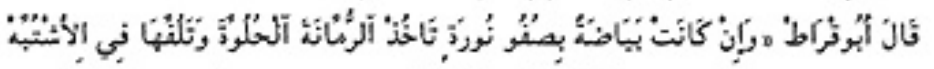

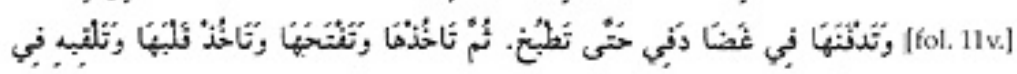

10

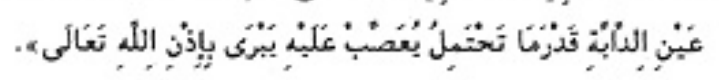

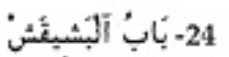

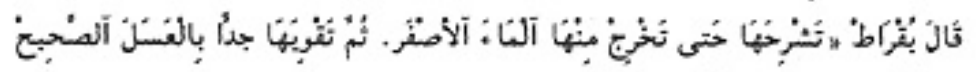

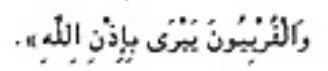

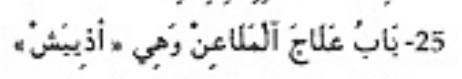

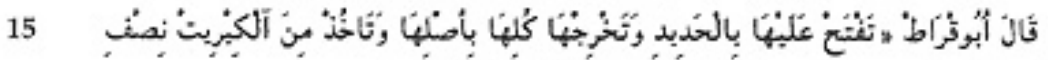

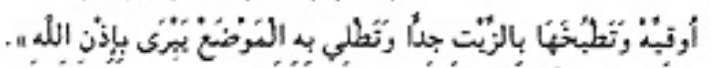

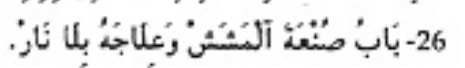




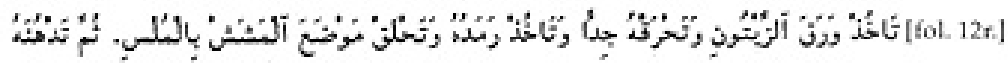

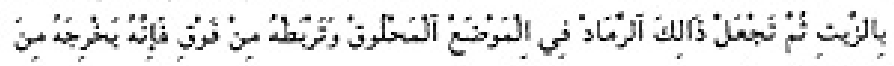

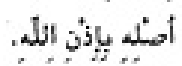

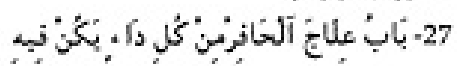

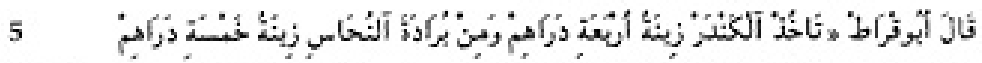

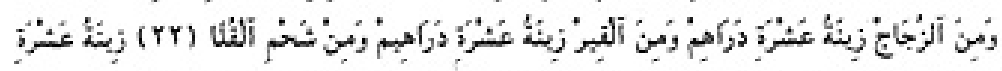

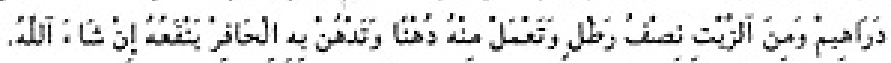
28 [fol. 12v-]

10

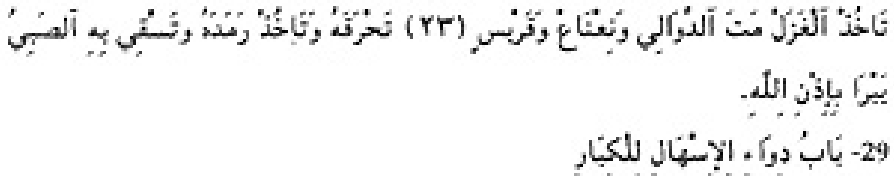

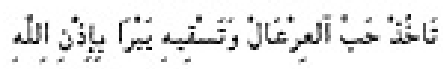

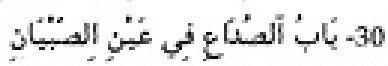

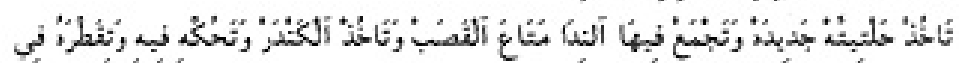
15

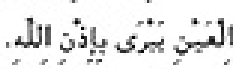

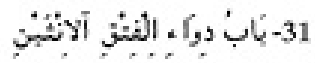

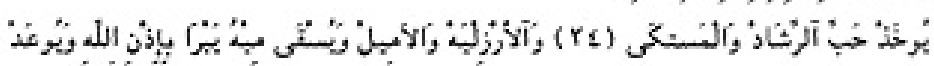
بالجزئز

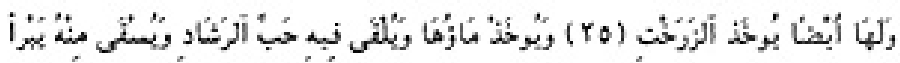




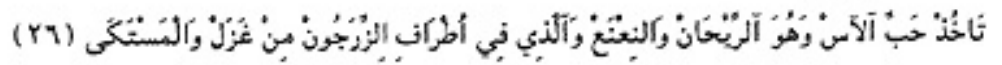

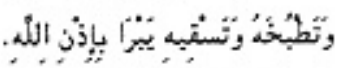

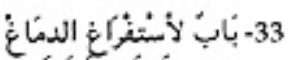

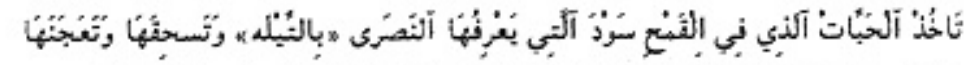

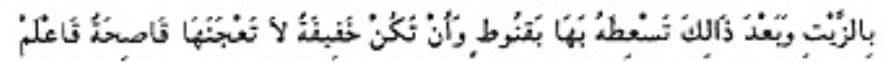

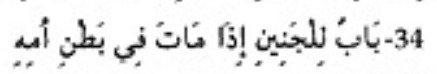

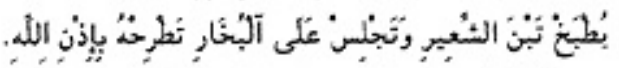

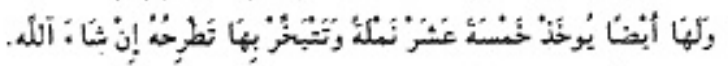

10

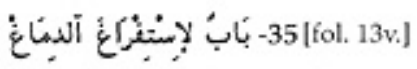

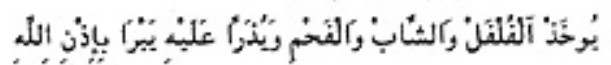

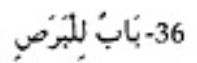

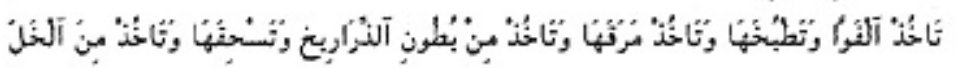

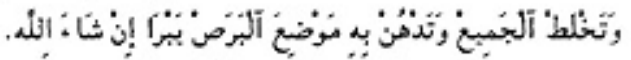

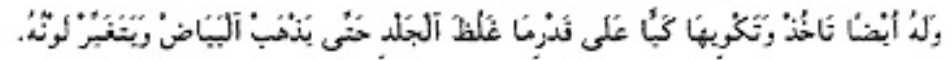

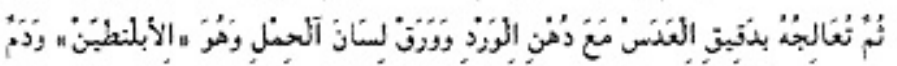

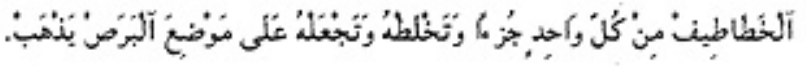




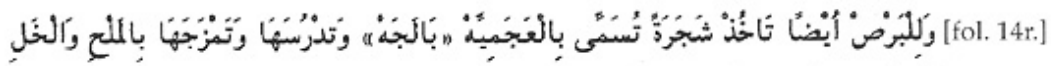

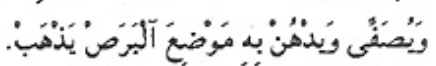

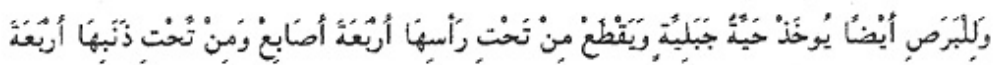

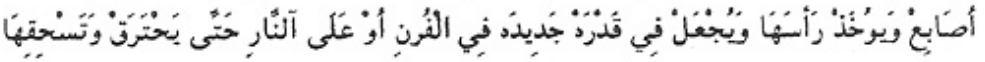

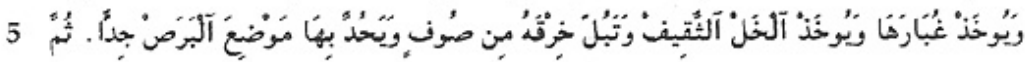

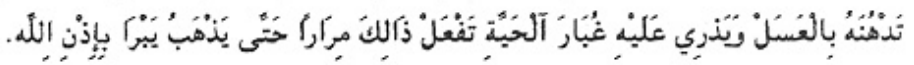

[fol. 14v.]

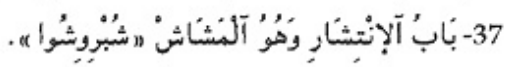

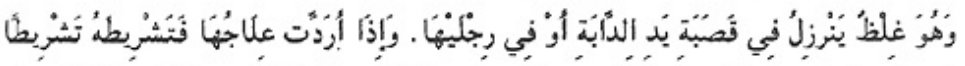

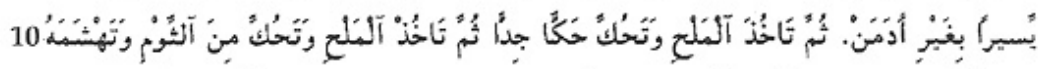

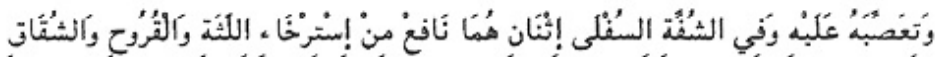

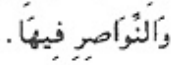

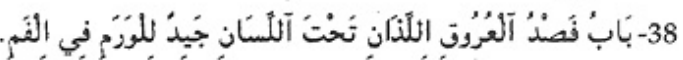

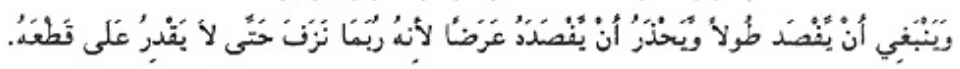




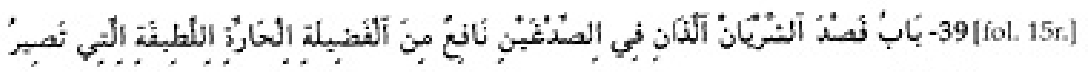

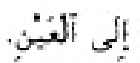

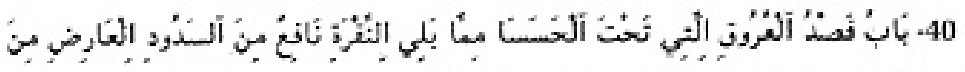

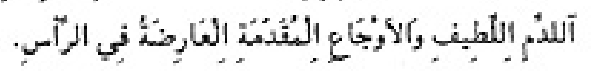

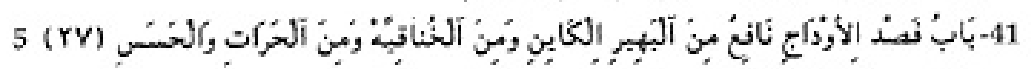

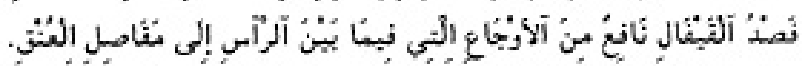

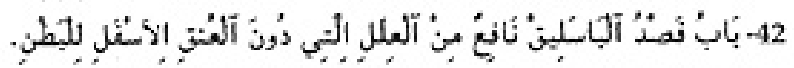

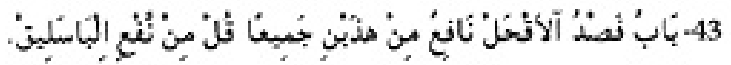

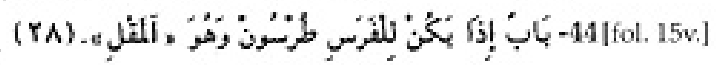

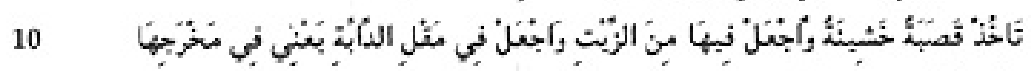

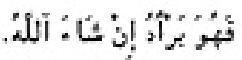

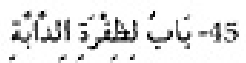

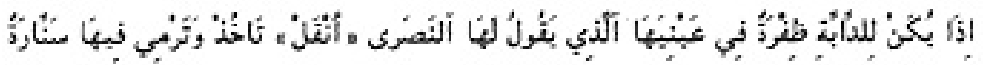

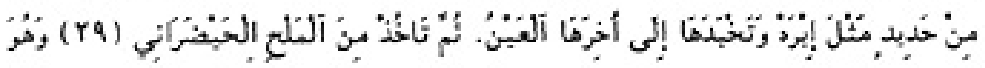

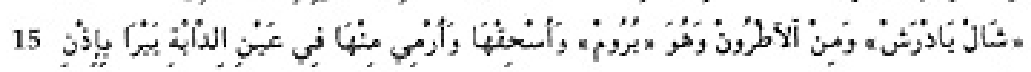

$$
\begin{aligned}
& \text { الله. } \\
& \text { 46- بَابِ آلَليَدُوا }
\end{aligned}
$$

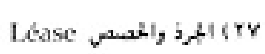

$$
\begin{aligned}
& \text { Léase dis }
\end{aligned}
$$

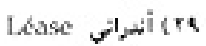




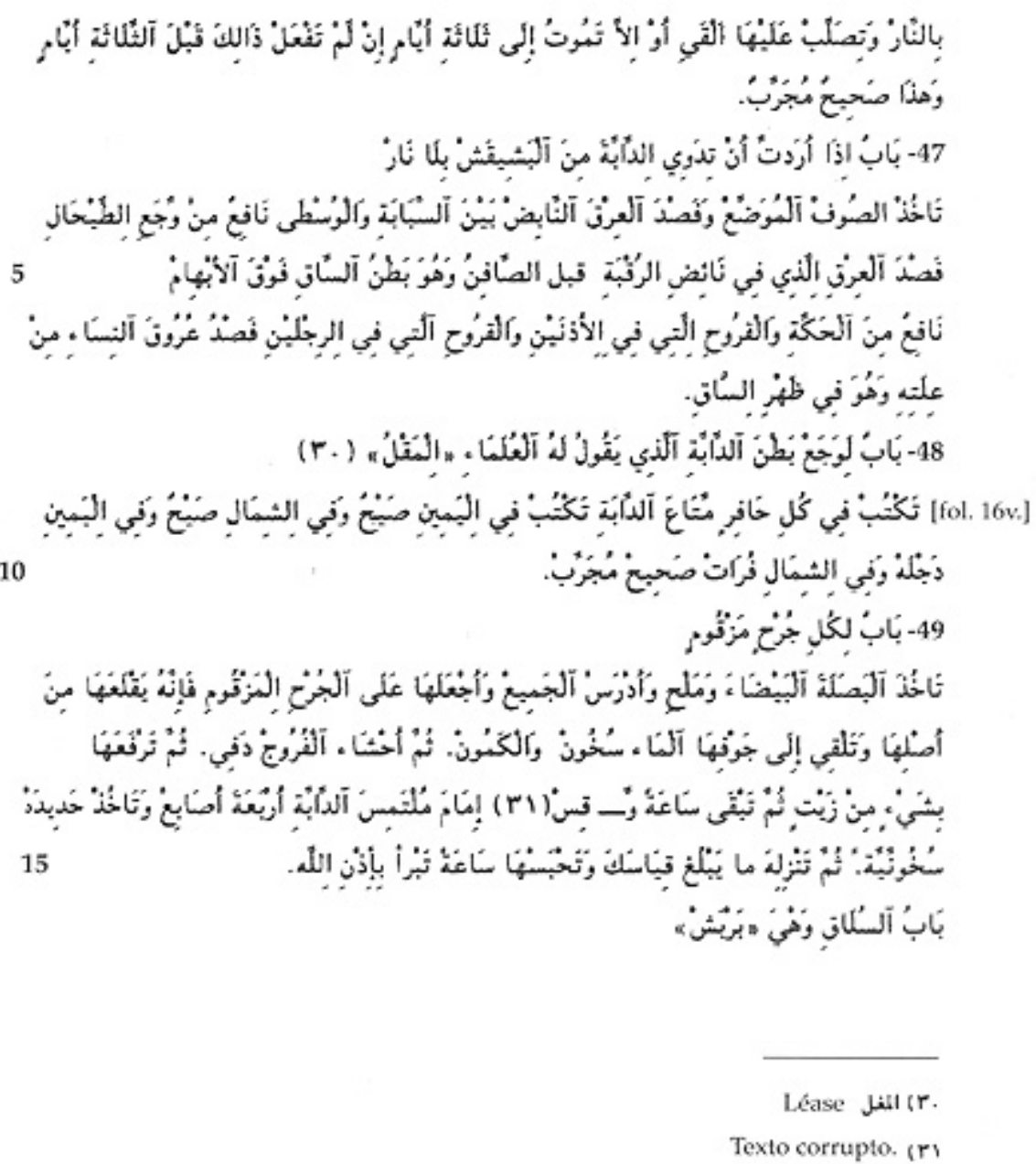




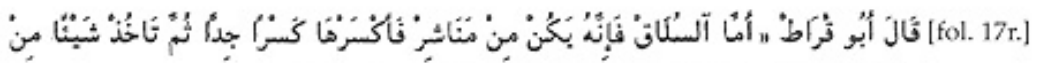

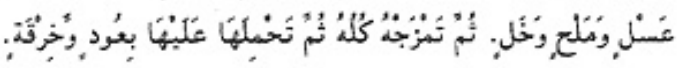

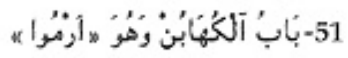

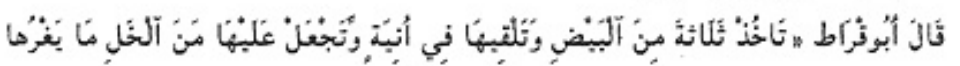

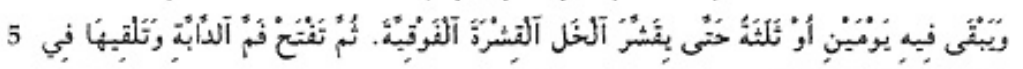

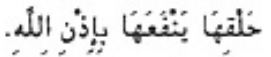

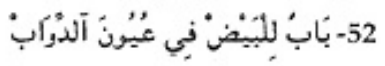

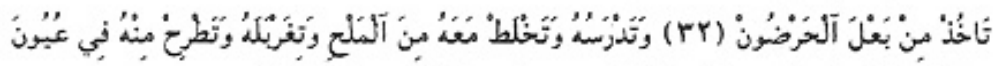

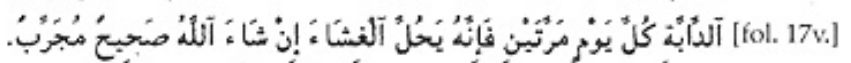

10

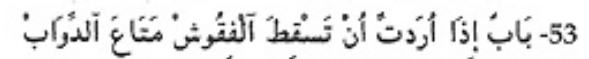

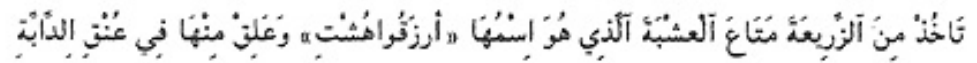

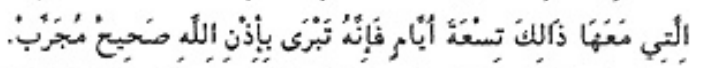

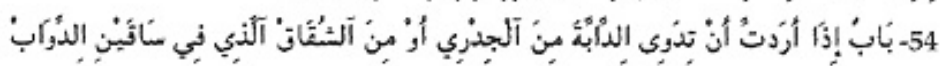

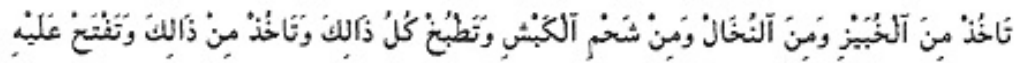

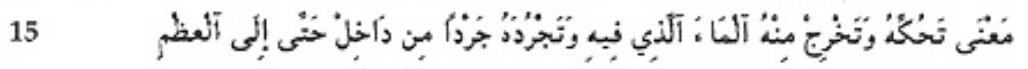




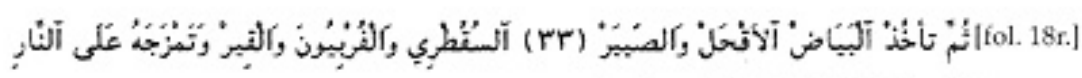

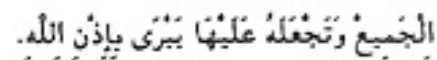

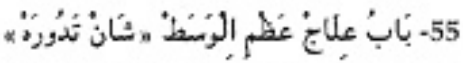

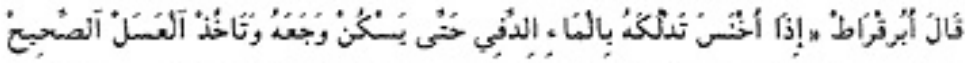

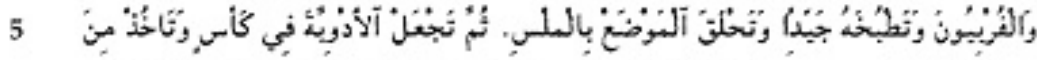

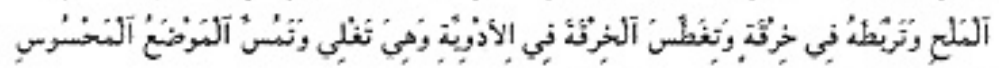

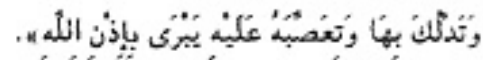

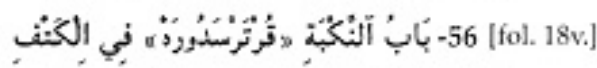

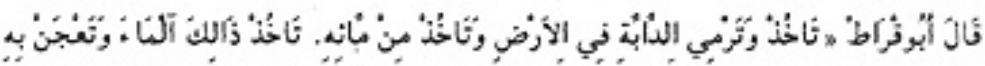

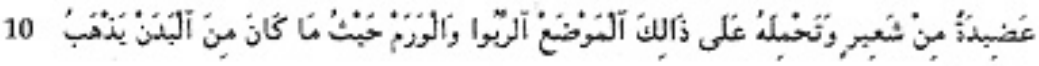

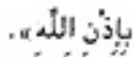

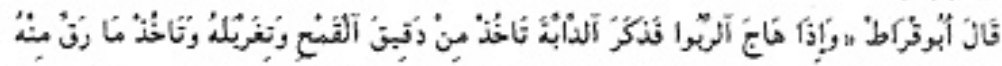

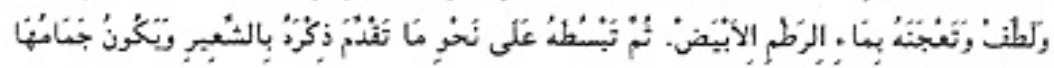

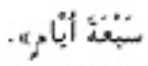
15

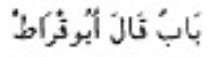

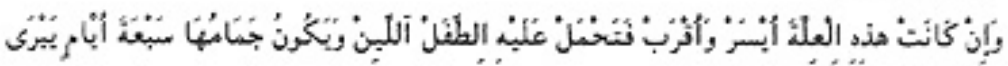

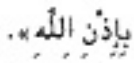

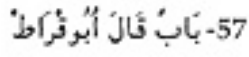




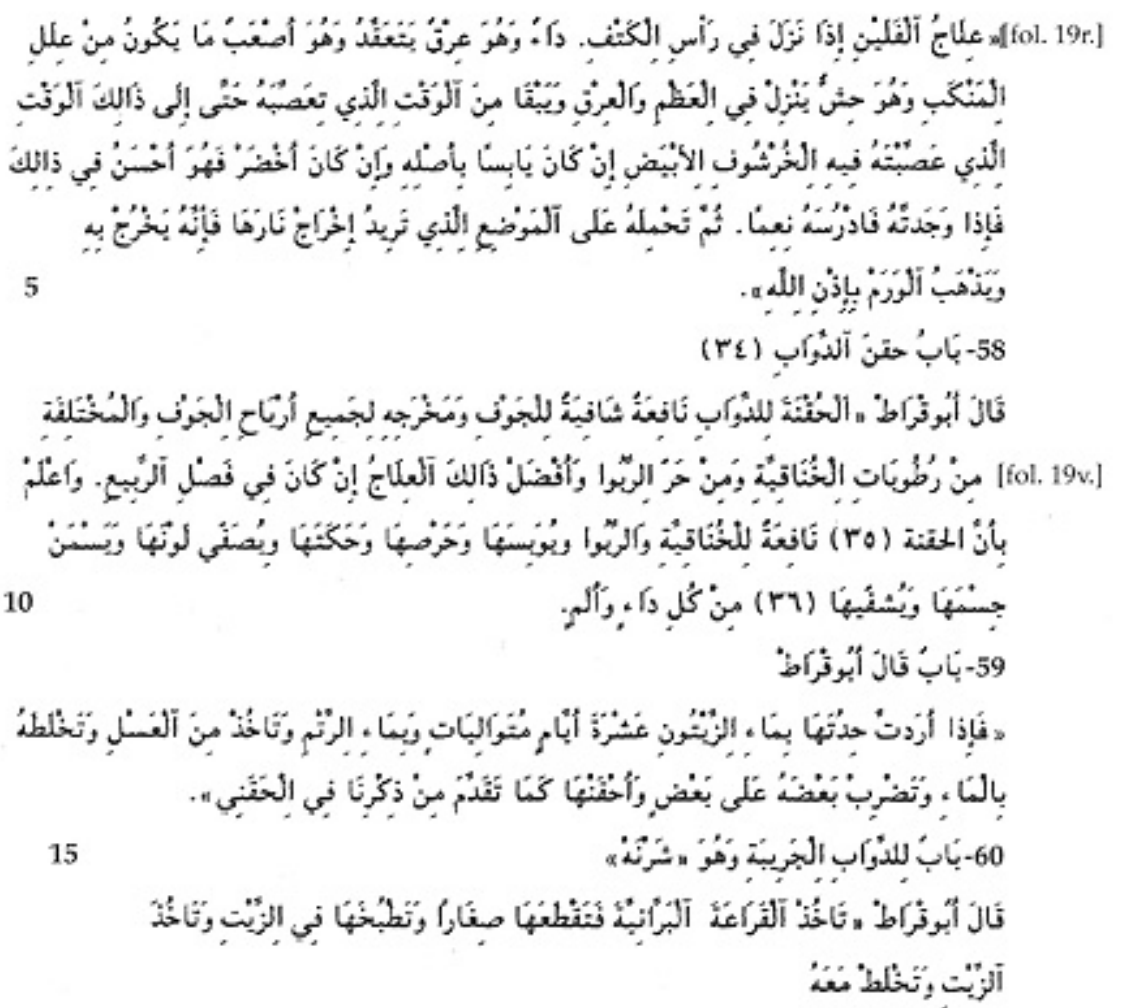




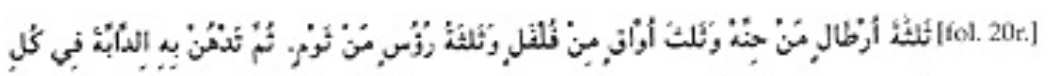

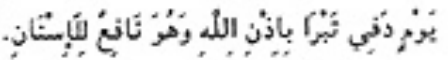

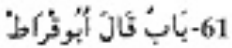

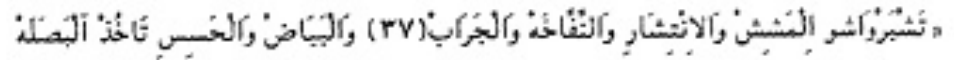

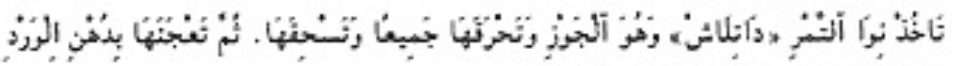

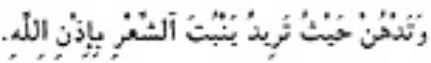

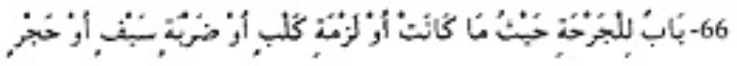

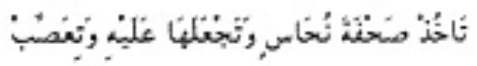


[fol. 21r.]

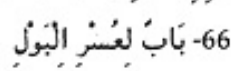

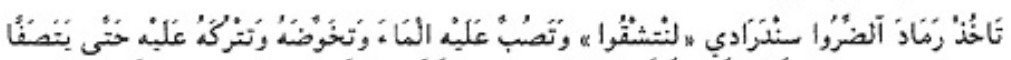

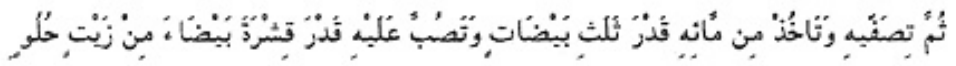

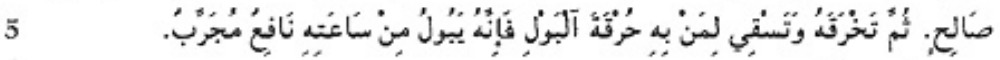

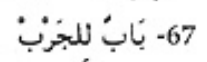

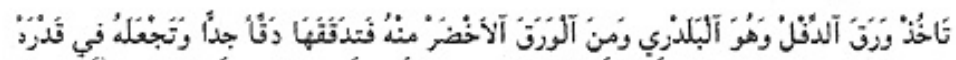

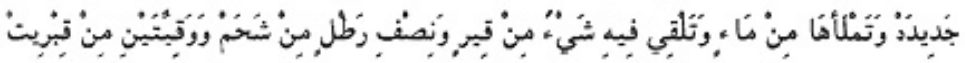

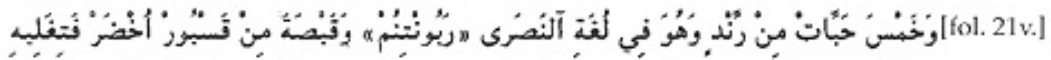

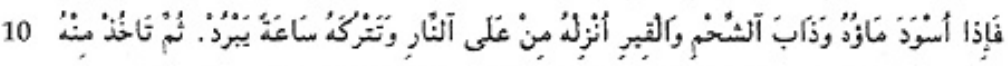

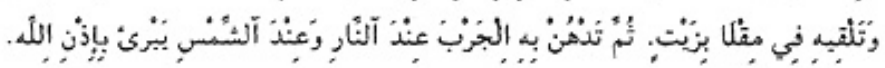

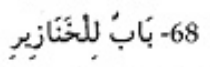

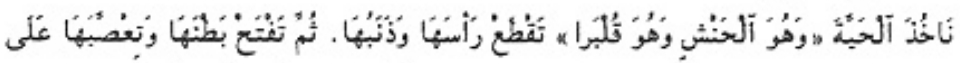

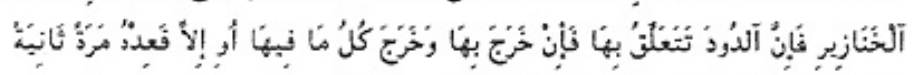

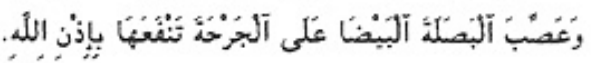

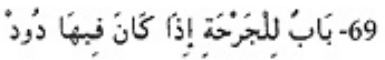




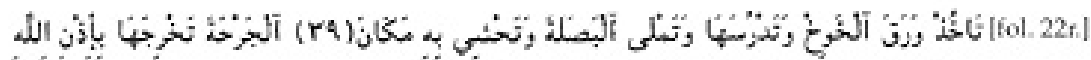

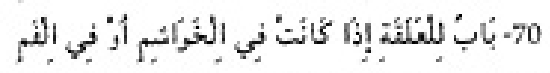

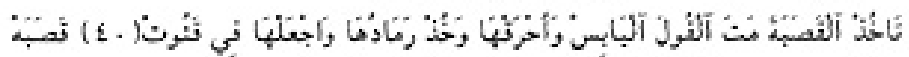

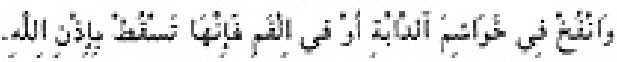

5

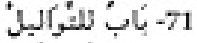

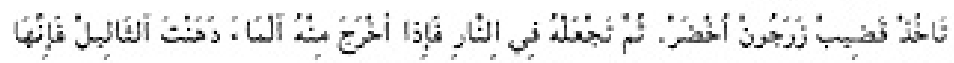

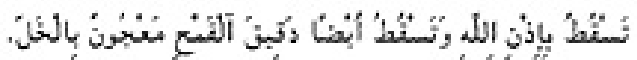

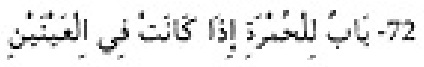

10

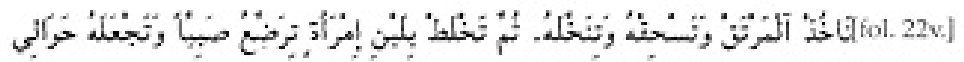

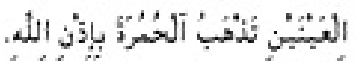

23- 73

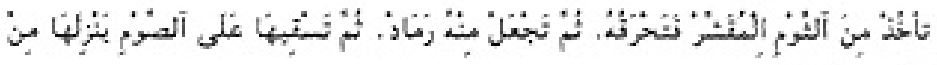

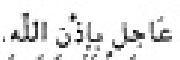

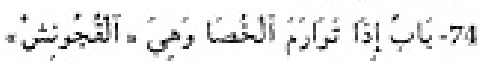

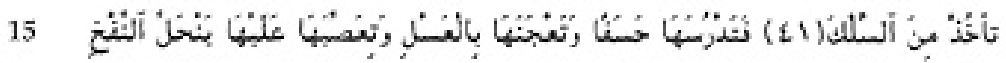

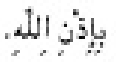

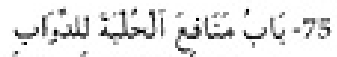

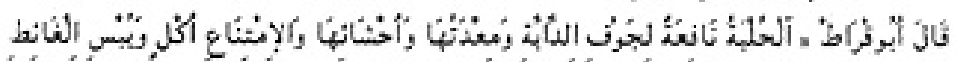

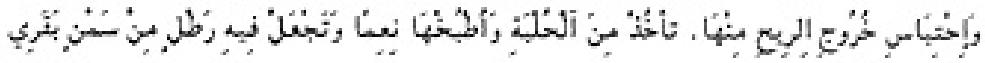

20

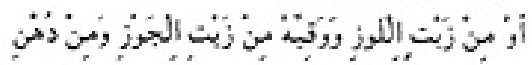

Elermino مك se escribe en el margen. Ifs

Léase bit it.

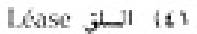




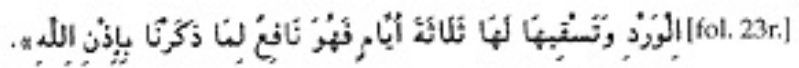

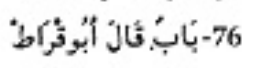

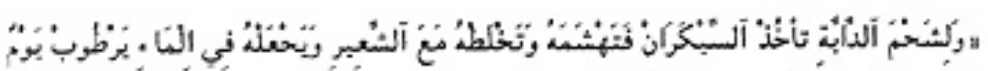

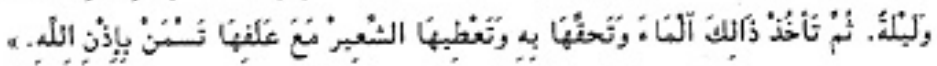

5

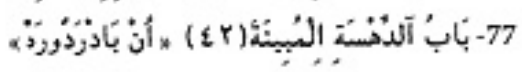

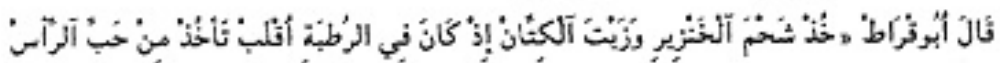

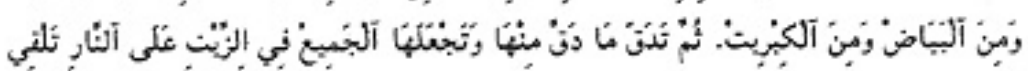

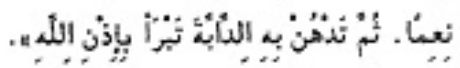

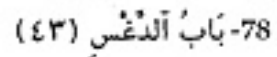

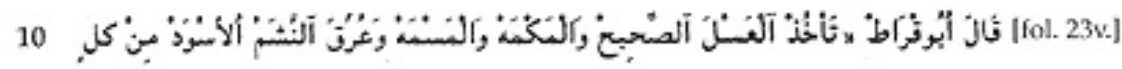

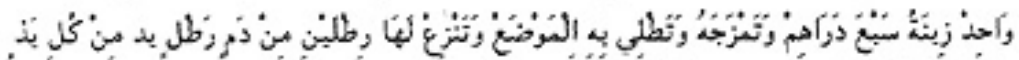

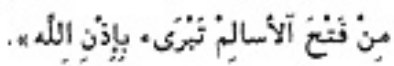

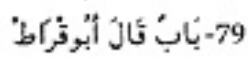

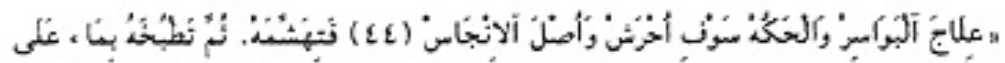

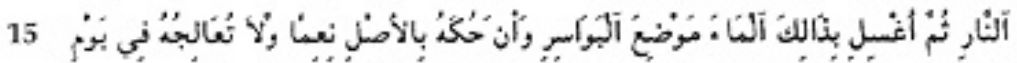

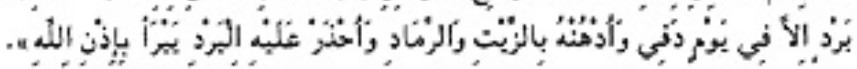

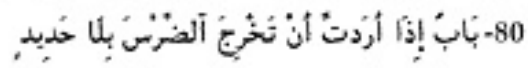




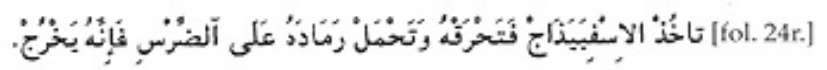

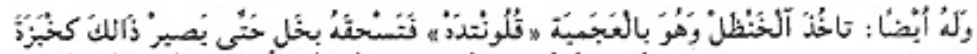

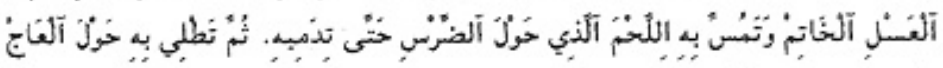

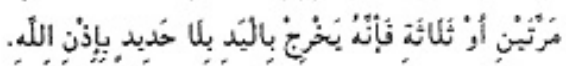

5

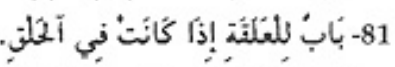

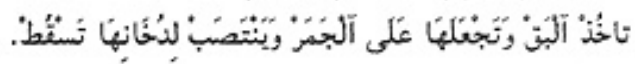

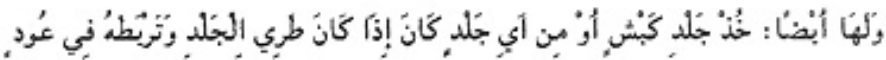

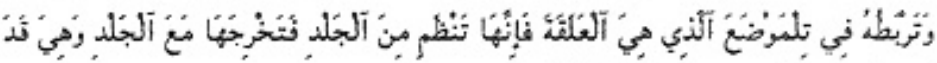

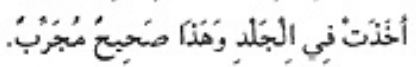

10

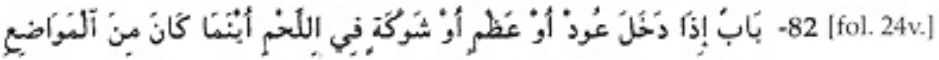

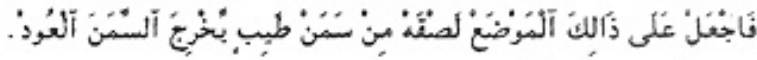

$$
\text { 83- بَابِ لنبَّات الشُعر }
$$

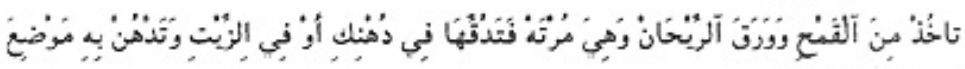

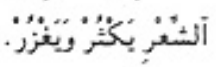

15

$$
\text { 84- بَابْ للجزَّب }
$$

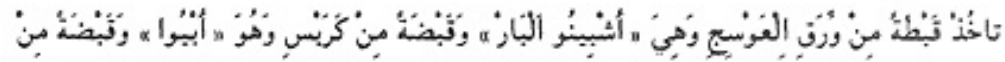

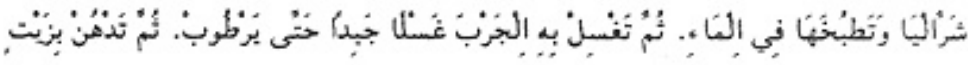

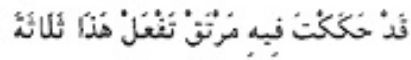




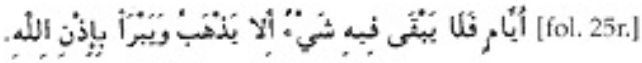

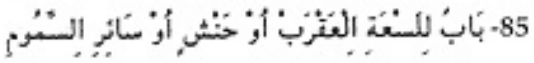

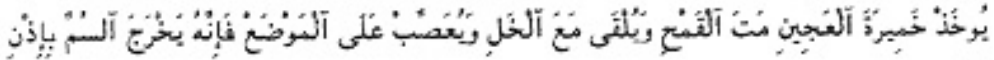

$$
\begin{aligned}
& \text { الله. } \\
& 5
\end{aligned}
$$

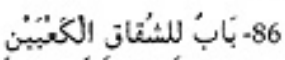

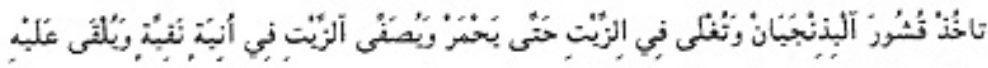

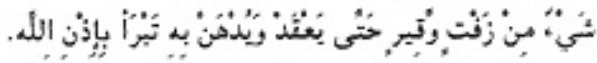

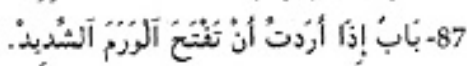

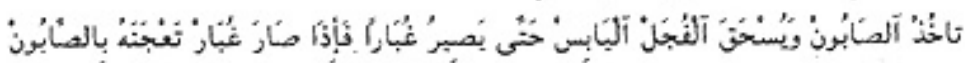

$$
\begin{aligned}
& 10
\end{aligned}
$$

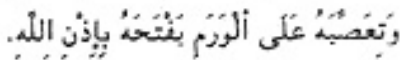

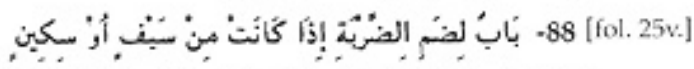

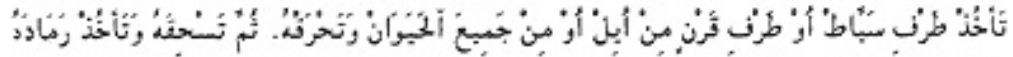

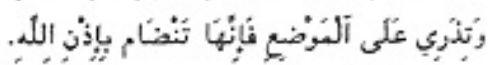

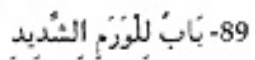

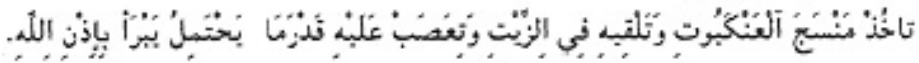

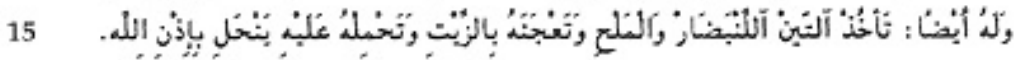

$$
\begin{aligned}
& \text { 90-بَابْ لدكاء الشُوكتة }
\end{aligned}
$$

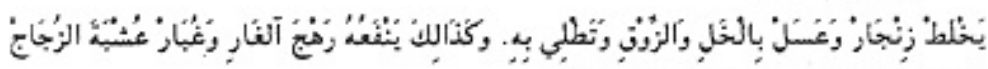

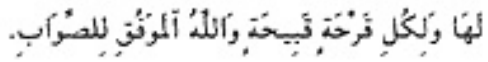




$$
\begin{aligned}
& \text {-ra- }
\end{aligned}
$$

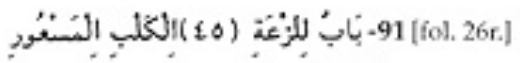

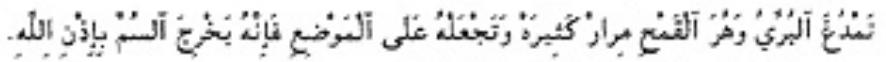

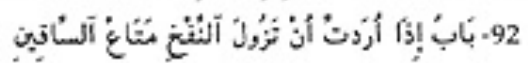

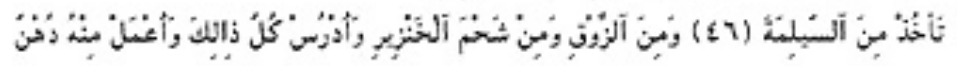

$$
\begin{aligned}
& 5
\end{aligned}
$$

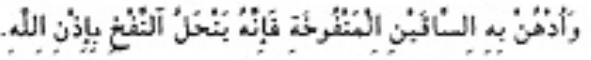

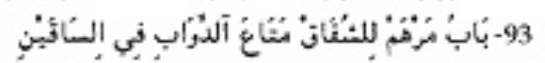

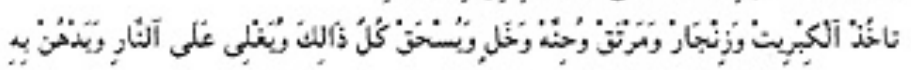

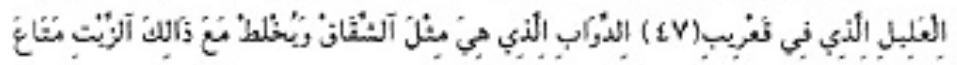

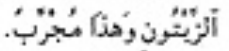

$$
\begin{aligned}
& 10
\end{aligned}
$$

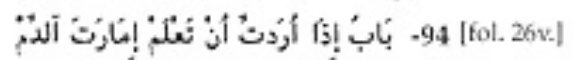

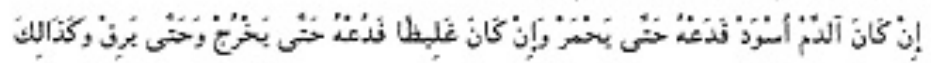

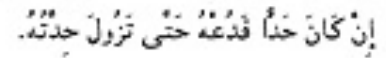

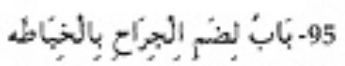

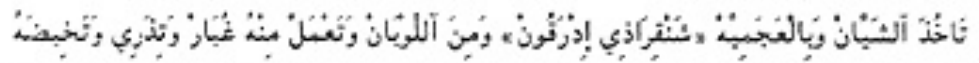

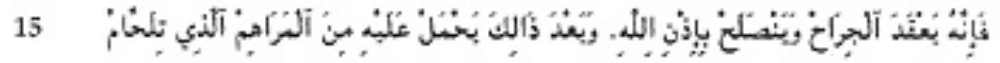

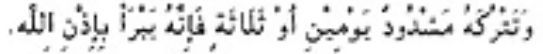

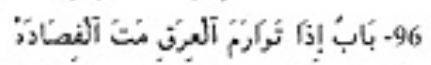

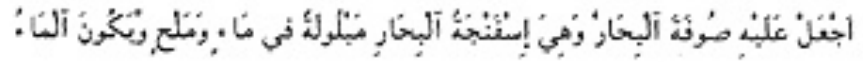




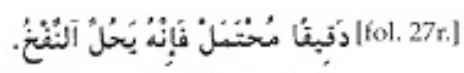

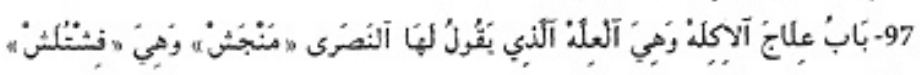

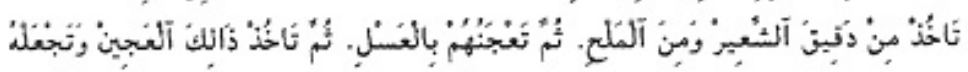

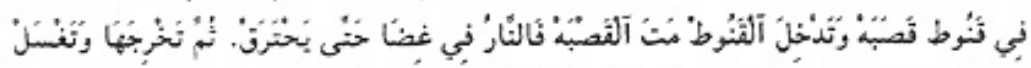

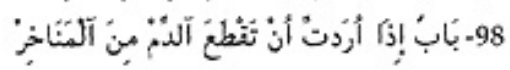

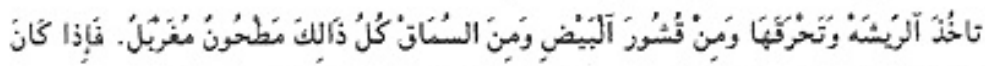

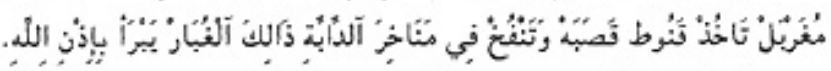

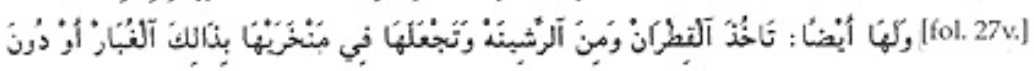

10

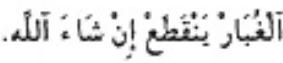

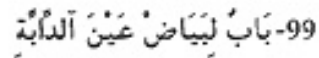

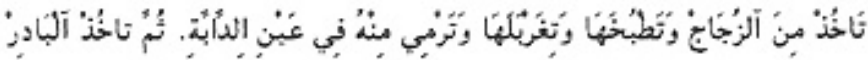

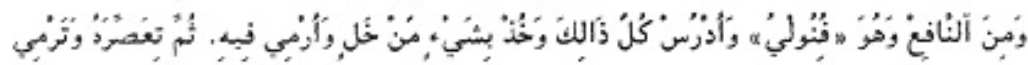

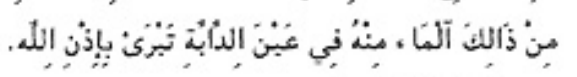

15

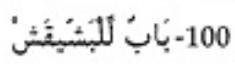

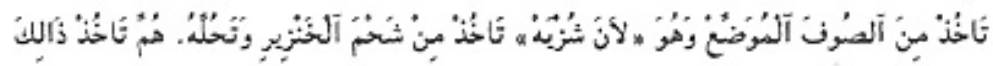

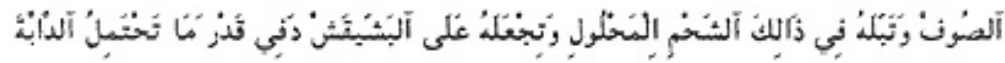

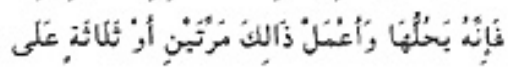




$$
\begin{aligned}
& -\mathrm{rV}-
\end{aligned}
$$

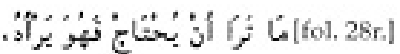

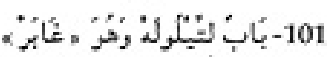

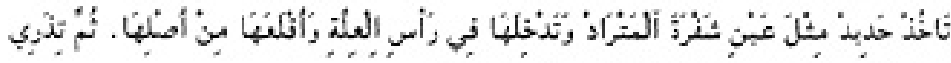

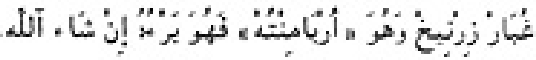

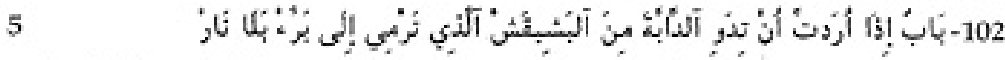

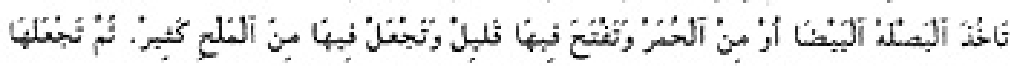

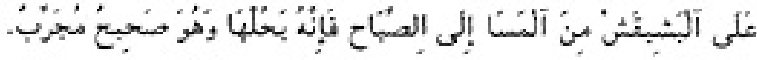

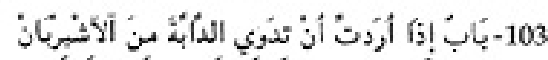

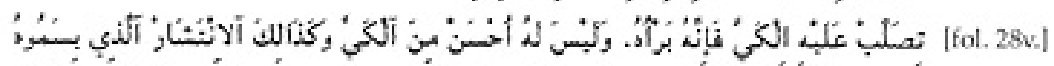

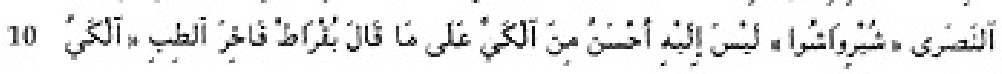

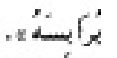

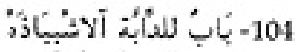

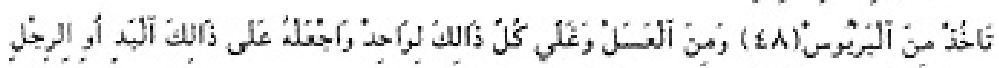

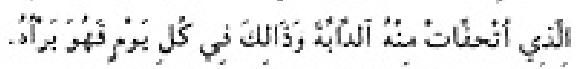

$$
\begin{aligned}
& 15
\end{aligned}
$$

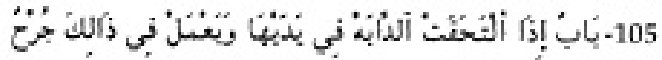

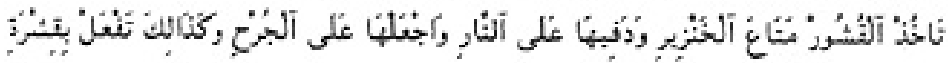

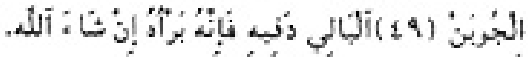

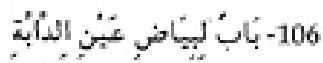

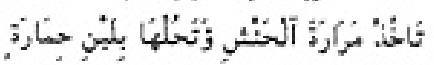




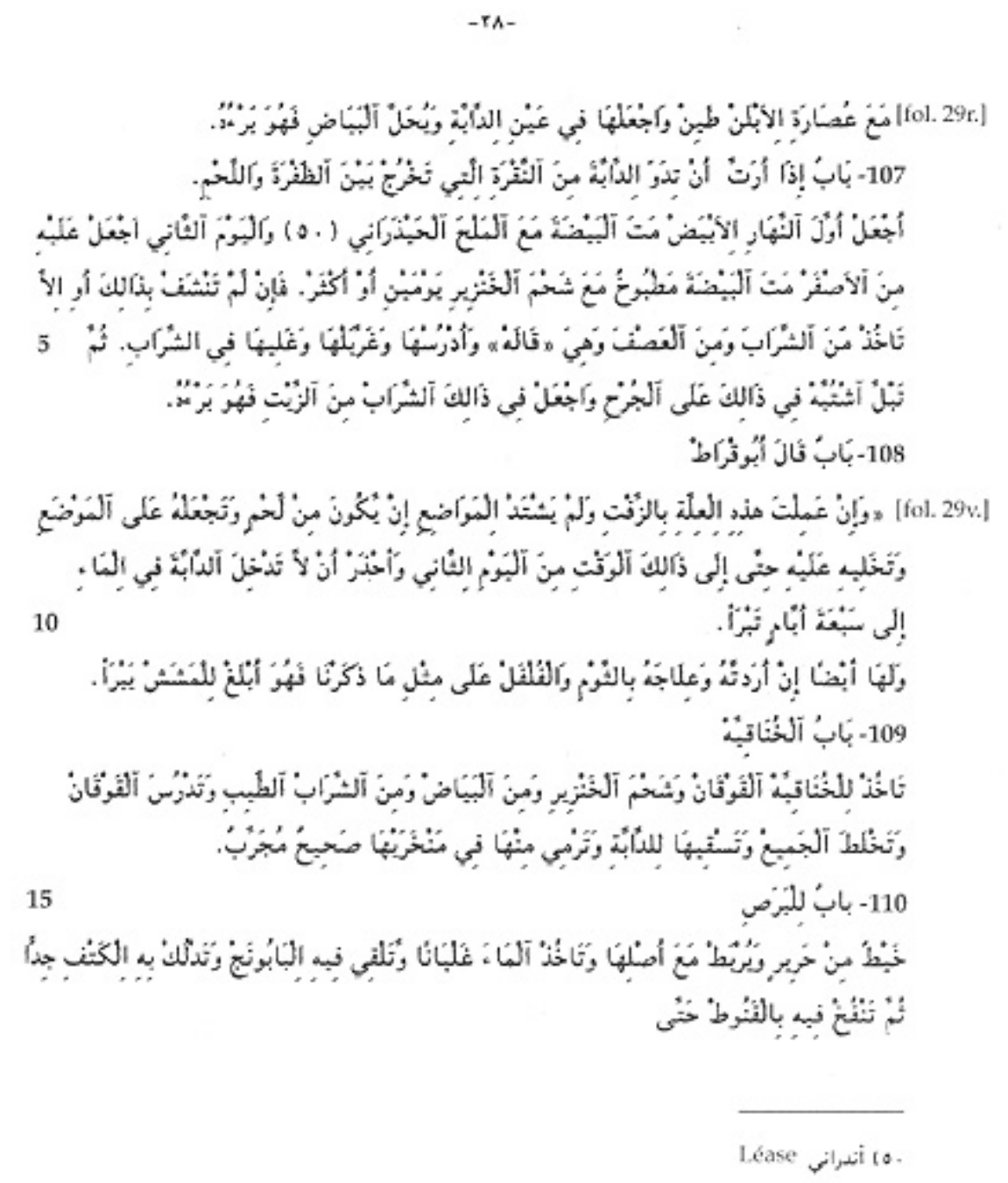




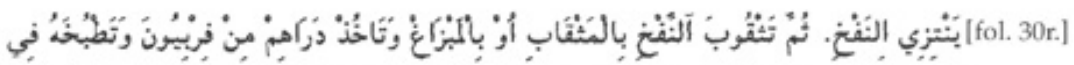

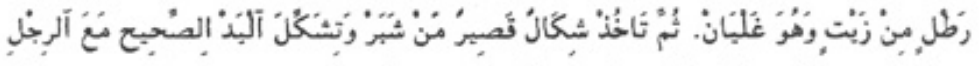

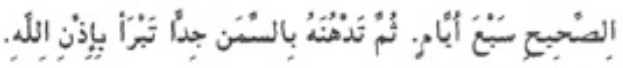

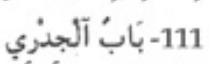

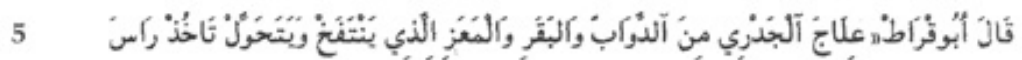

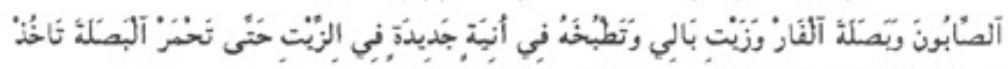

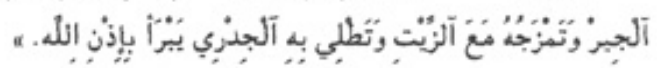

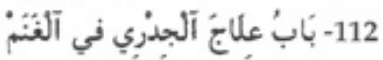
[fol. 30v]

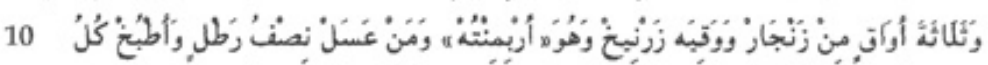

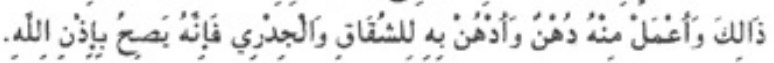

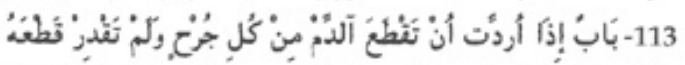

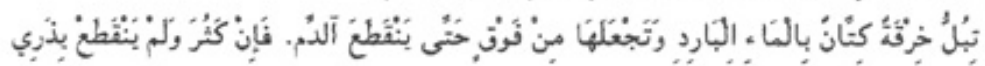

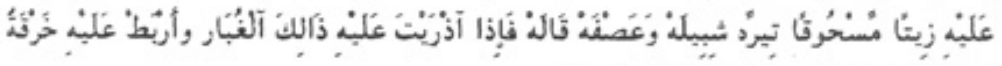
15

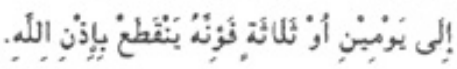

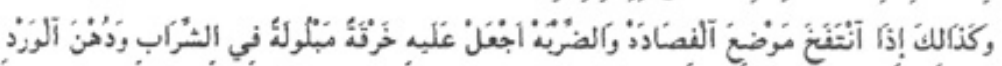

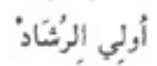




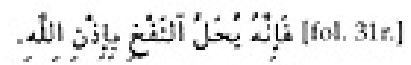

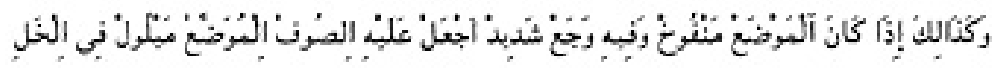

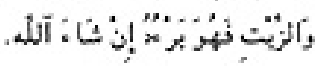

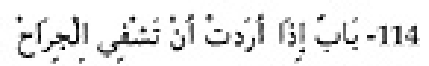

5

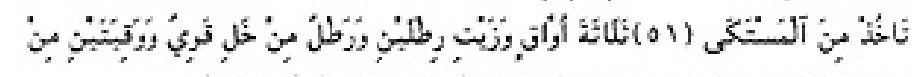

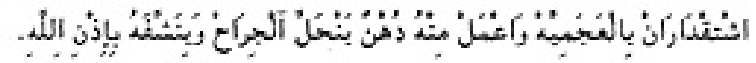

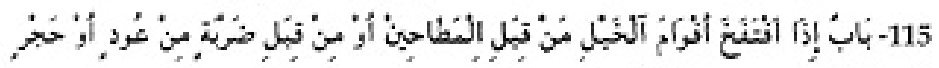

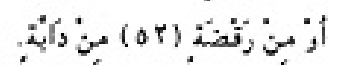

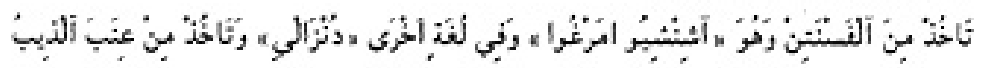

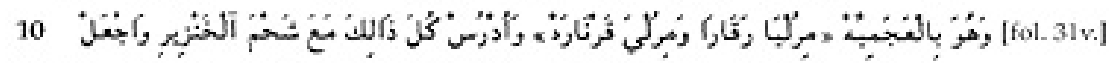

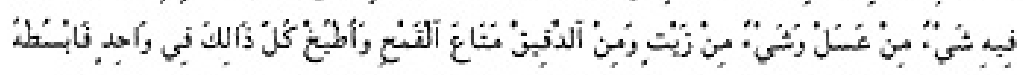

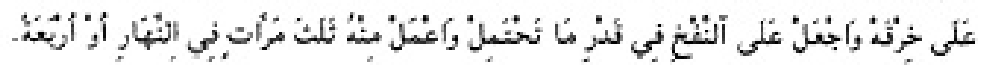

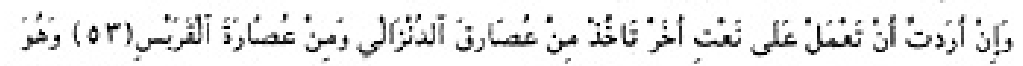

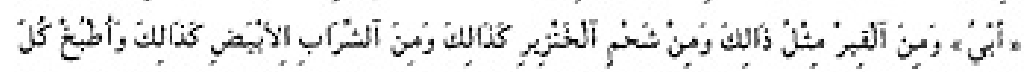

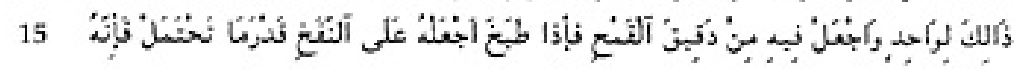

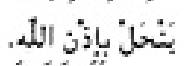

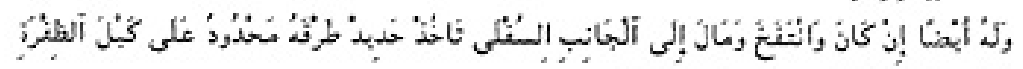

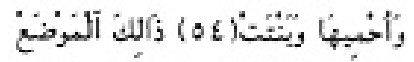

\footnotetext{
Léase stilor

Letase is sor

Lase mes bor

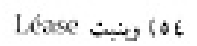




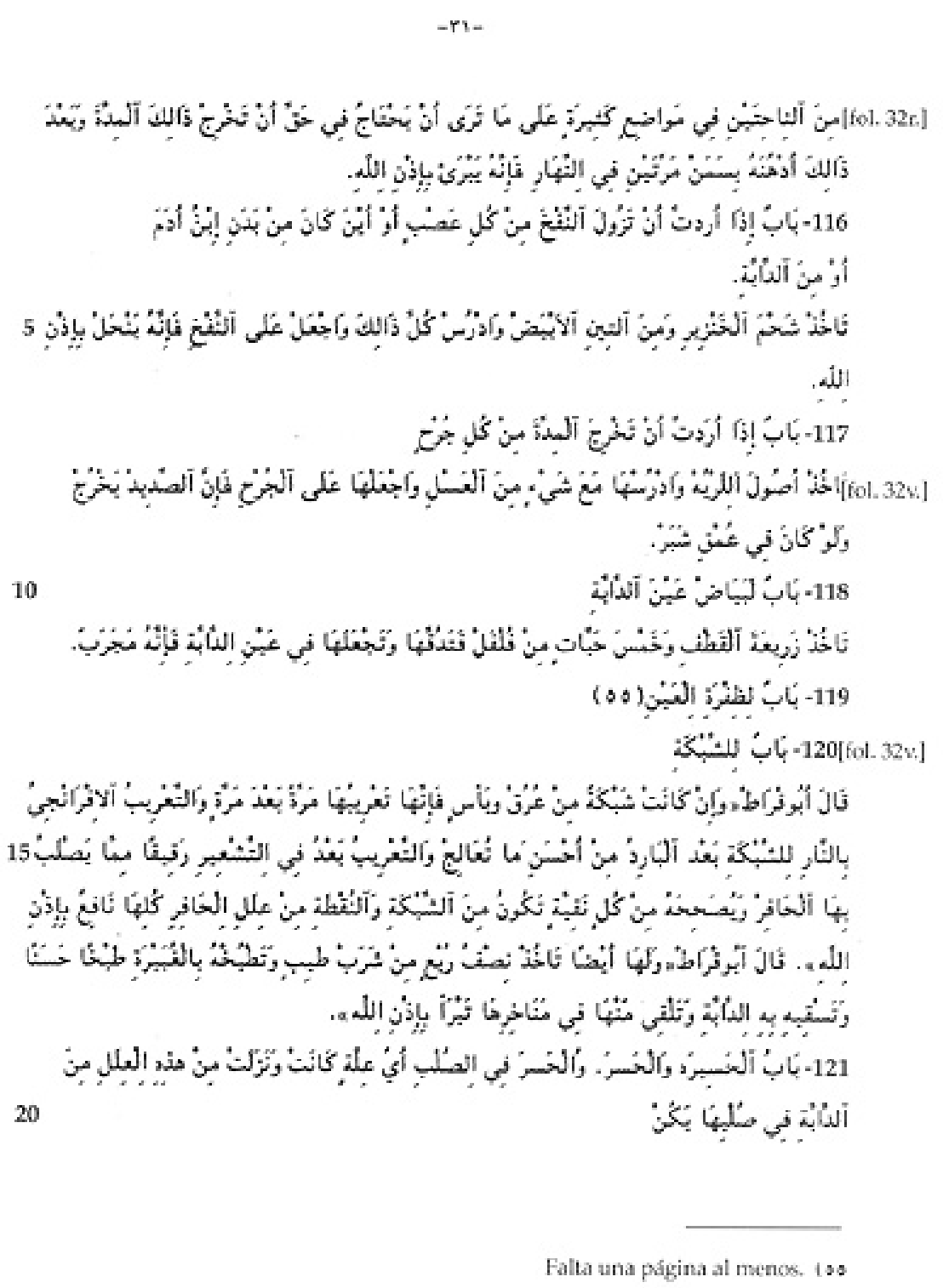




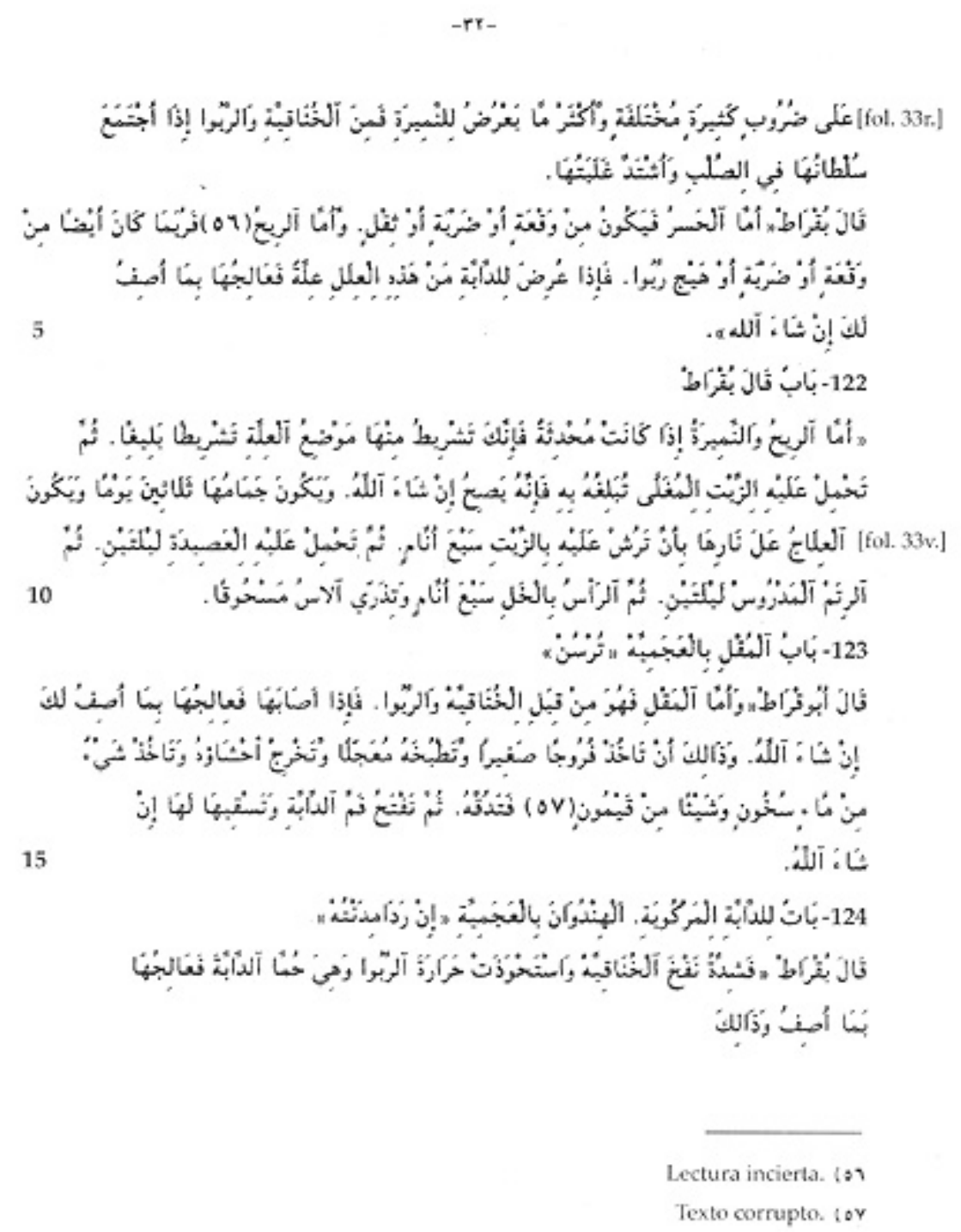




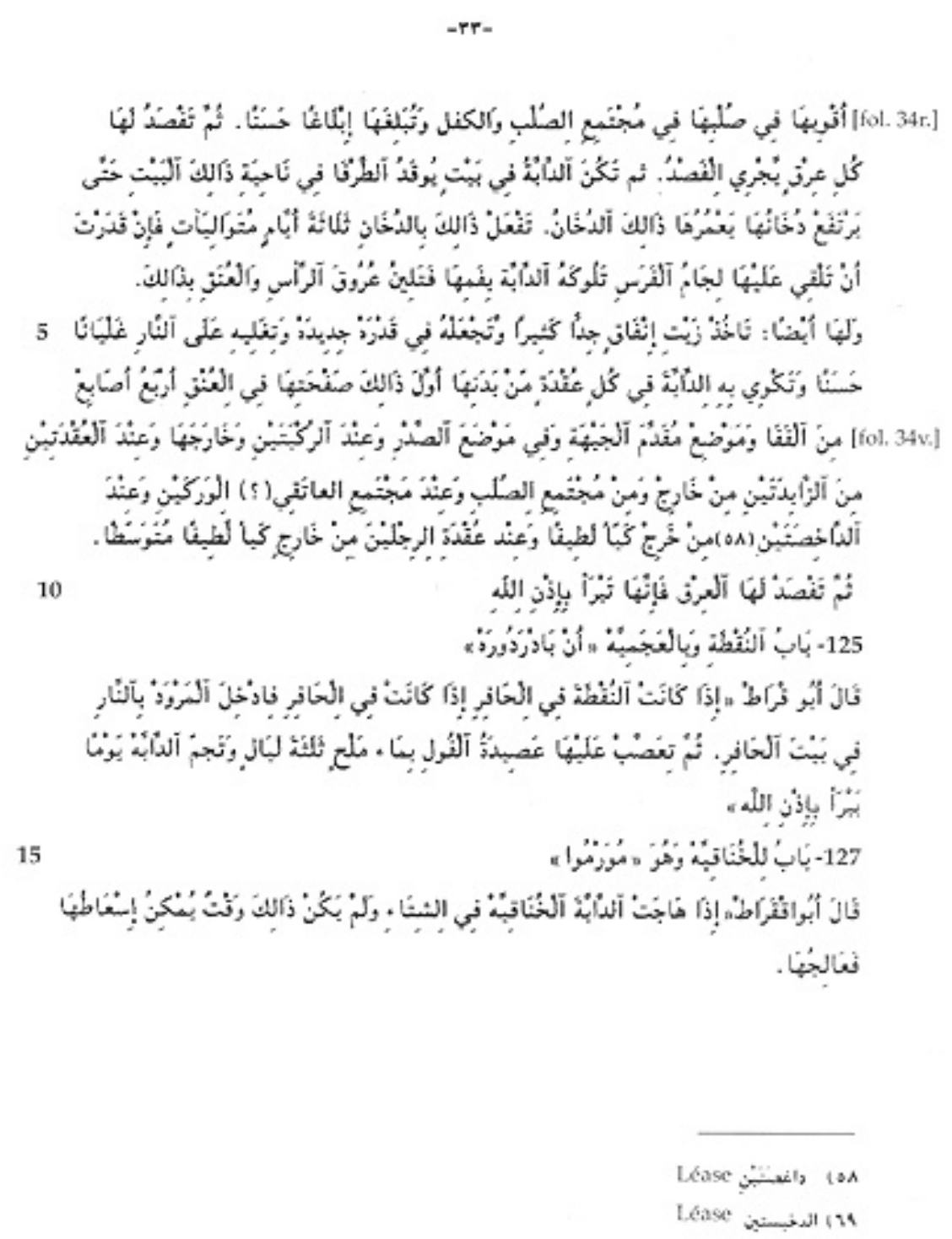




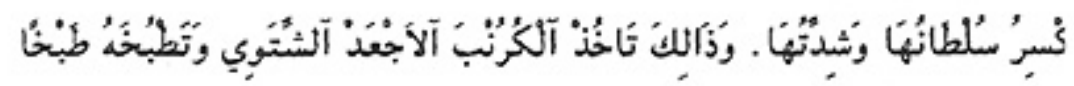

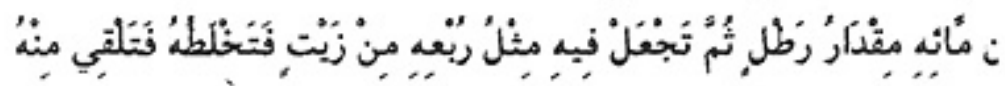

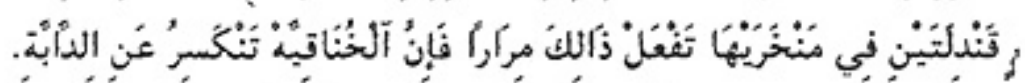

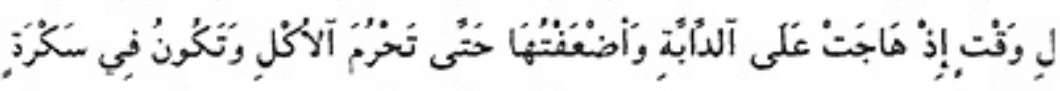

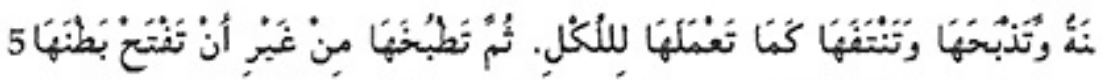

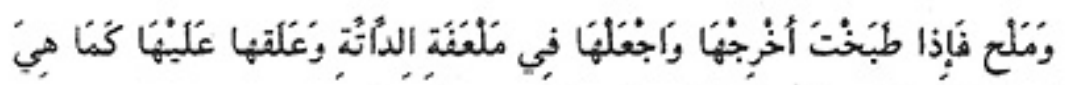

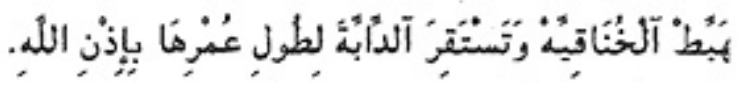




\section{TRADUCCIÓN}

Libro que contiene temas concernientes a veterinaria y asuntos semejantes que revisten gran utilidad

¿Quiéralo Dios, El que proporciona el camino recto!

1. Descripción de un remedio eficaz para cualquier mal en los ojos.

Coge, jla bendición de Dios sea contigo!, una porción de escoria de bujía, ponla en un poco de agua hasta que se ablande y adquiera esa agua tonalidad amarilla, exprime a continuación jugo de granada dulce en una cantidad equivalente a la cuarta parte del agua, y añade cardenillo y azúcar de Salomón, triturados y tamizados, en la cantidad de una onza por cada arrate de agua empleada.

Trabaja todo y confecciona un unto que aplicarás en untura cuando lo consideres necesario, porque su resultado es excelente. ;Permitalo Dios! [fol. 2 r.]

2. Sobre cómo conocer la edad de las bestias.

Sabe, Dios te guarde, que todo animal a los treinta meses muda un par de muelas de arriba y abajo. En el momento que el animal cumple tres años y medio cambia dos de sus molares también y entonces es de cuatro muelas. Cuando el animal haya cumplido cuatro años y medio, es decir sea fresca e igualada ${ }^{31}$, aplícale esta untura: coge grasa de carnero, cera, goma y trementina y haz en ello un ungüento y unta a la bestia dos veces al día, porque sanará. ¡Permítalo Dios!

31. Tanto en el Libro de Agricultura de Ibn al- ${ }^{c}$ Awwām (II, XIV, p. 517) como en el Tratado de Hipiatría de Ibn Hudayl (fol. 140r, ms, n XLII de la Real Academia de la Historia "Colección Gayangos") se encuentra el antecedente de este capítulo, si bien nuestro texto -como ocurrirá casi siempre- se presenta incompleto y desordenado frente a las fuentes árabes: "De lo que da a conocer la edad de las bestias, lo cual se indica por las muestras de su dentadura y lo que acaeciere de nuevo en ella [...] toda bestia tiene quatro dientes delanteros, quatro segundos, quatro terceros, quatro caninos, y dientes molares. Los primeros que le nacen al potro son sus quatro dientes delanteros [...] sus cuatro segundos nacen después de los dos meses de nacidos, y los quatro terceros después de los ocho meses hasta los de su nacimiento. El potrillo recién nacido (se llama) faluón [...] al acercarse el año es hayliyon (o anniculo) [...] cumplido el segundo año jadaón [...] cumplido el año tercero es tsaníyo (o que ya los ha arrojado) [...] quando ha mudado los quatro segundos dientes es rabaíyon [...] quando ha mudado sus quatro terceros dientes es karihón [...] fuera de lo que hemos expresado nada más muda de sus dientes, y llámase farasón (o caballo ya hecho), no por los años que tiene, sino por los dientes que ha mudado". Ibn Hudayl dice: "De cómo conocer la edad de las bestias por sus dientes: has de saber que los primeros dientes que le salen al animal son dos, de arriba y de abajo, llamándose a estos tinâay y el animal recibe entonces el nombre de $\hat{y} a d a$ (cría); después le salen otros dos próximos a estos, a la derecha y a la izquierda, arriba y abajo que reciben el nombre de al-wust $\bar{a}$ (intermedios) y al animal se le llama tanīyya (que tiene ya cuatro incisivos); después le salen otros cuatro dientes, dos arriba y dos abajo, y son los últimos dientes que le salen, llamándose el animal $r u b^{c}$, porque estos cuatro últimos dientes que le han salido se llaman rabāa iyyāt (dientes entre incisivos y caninos). 
$Y$, si quieres hacer otro ungüento, coge 5 onzas de [i...? $]^{32}$ [fol. 2v.]

3. Un aserto de Hipócrates:

"Si quieres, cauteriza la bestia con aceite en muslos, patas y articulaciones del pie, se curará”. ¡Permítalo Dios!

4. Sobre la despeadura, que en romance es "calambre",33.

Cuando se presente ante ti el animal despeado en compañia de su dueño, pregunta a éste su nombre y el nombre de su madre. Cuando haya respondido, invoca el nombre de Dios diciendo: "Juro por Dios que los cielos han enviado una despeadura que aqueja a la pezuña del animal de fulano hijo de fulano. Yo haré ensalmo y Dios curará".

Coge a continuación un pelo de la bestia y vuelve a hacer el hechizo pronunciando las mismas palabras, mas haciendo a la vez dos nudos con aquél y repitiendo lo mismo al final de cada nudo. Ata seguidamente el pelo ensalmado anudado en la pata del animal diciendo [i...? $]^{34}$ [fol. 3 r.] culantrillo de pozo y tritúralo bien. Unge a continuación con miel la verruga y véndala bien con coriandro día y noche. Repite la operación varias veces, porque se curará. ;Permítalo Dios!

Otro procedimiento:

Coge agua hervida hasta bullir en el recipiente y aceite, y untas la verruga y después la vendas, desaparecerá rápidamente. ¡Permitalo Dios!

5. Sobre la torsión.

Hipócrates dice: "Cuando el animal es aquejado de contorcim(i)ento, cauterizalo con un hierro cada cuatro dedos, bien sujetado, desde el tendón de Aquiles hasta la base del fémur, porque se cura”. ¡Con el permiso de Dios! [fol. 3 v.]

6. Un aserto de Hipócrates:

"Coge tamarisco tierno, cuécelo bien hasta que se ablande y disuelva, retíralo del fuego para que llegue al vientre del animal. Si con una ingesta no bastara, dale otra, porque el mal desaparece”. ¡Permítalo Dios!

32. La última línea del folio se haya corrupta por la humedad.

33. La voz castellana "calambre" -como sucede otras veces en este texto-no corresponde al término árabe. En cuanto a dahfa es deformación de rahsa. Ibn al- ${ }^{\mathrm{c}}$ Awwām, Tratado de Agricultura, II, p. 635, trata este mismo mal diciendo: "la lesión que acaece a las bestias en los cascos de sus manos (al-rahsa) se conoce, si al andar el bruto así herido avienta su casco la tierra que coge debaxo solamente, habiendo juntamente en él fuerte recalentamiento. También proviene esa lesión de las piedrezuelas o cosa semejante sobre que haya pisado el bruto con las ranillas de sus cascos, de que resulta que coxée y que se forme en el casco cosa que le eche fuera".

34. Cf. el apartado Confrontación de las fuentes, donde indicamos que esta receta mágica ha sido tomada del Tratado de Hipiatría de Ibn Hudayl (fol. 132v). Por otra parte, el texto presenta en este punto una laguna saltando a otro tema. 
7. Sobre la reticulación y el dájaso, es decir "ferida",35.

Hipócrates dice: "Esta clase de úlcera acaece, bien por infección en la sangre, bien por exceso de fatiga. Si es deformación reciente, trátala cauterizando con frío, o mejor con fuego. $Y$, si se hace crónica, y no la curas, no intentes más tratamiento que la untura con óleos. ¡Quiéralo Dios!

8. Un aserto de Hipócrates:

"La incisión con cauterio en la reticulación con brea y grasa continuará durante varios días, porque se curará”. ;Permítalo Dios! [fol. 4 r.]

9. Un aserto de Hipócrates:

"Si la reticulación tiene forma de hormiga, se llama "Hormiguillo", porque es su señal indicio de daño en la pezuña y con esto se curará" ¡Permítalo Dios!

10. Sobre la esquinancia o angina.

Coge malva, es decir, mirulyarqara, mirliyaqanarah o biyula, y salvado ${ }^{37}$. Hierve el agua producto de su cocción con dos onzas de cañafístula y medio arrate de

35. Tanto la "reticulación" como el "dájaso" son males tratados también por Ibn al-"Awwām e Ibn Hudayl. El primero, Libro de Agricultura (II, pp. 641 y 676) dice: “En la curación de la 'reticulación' y otras enfermedades se suele hacer la sangría en las venas inmediatas a la quartilla, y para romperlas has de ablandarlas con tu mano desde el nacimiento del brazo del bruto hasta la quartilla”. "El 'dájaso' (íd) es un morbo que acaece en la mano del bruto y de que también suele adolecer su pie; el qual es un tumor que aparece entre las cernejas y el casco por la parte interior y exterior, semejante o mayor que el huesecillo del dátil". En nota, Banqueri añade que acaso se trata del mal que es llamado por los veterinarios "clavo pasado". Ibn Hudayl, Tratado de Hipiatría (fol. 55v) dice también: "el dájaso es como un nudo en las mismas cernejas junto a la raíz del casco, similar al hueso de dátil, que suele inflamarse y se abren las venas de la zona donde está. No debe de tratarse con el hierro salvo cuando el tumor es duro. Si además este es duro y maligno es peligroso, y si es de formación reciente, trátalo; pero si se cronifica y se consolida, no lo trates más que con la untura (con óleos) y posteriormente con brea y cantáridas". En cuanto al castellano fädrudurah podría ser el catalán/aragonés o castellano antiguo "feridura", "herida"; actualmente se usa esta palabra en catalán para la hernia. Es normal además una vocal (u) por (i) en posición átona en este tipo de textos.

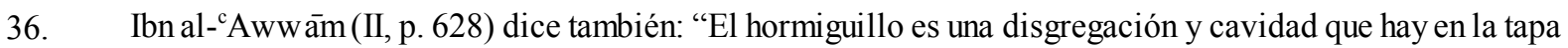
del casco, la qual acaece más frecuentemente en el jumento, y que es un morbo que sobreviene en el casco malo y enxuto; que cuando llega a las cernejas se empodrece, y saliendo de alli materia se corrompe en nacimiento del casco, que esta junto aquella corrupción". En veterinaria en efecto es "una enfermedad de los cascos de las caballerías, que los va deshaciendo", según María Moliner.

La última palabra de la línea está corrupta.

37.

Como ocurre otras veces en este texto (cf. nota 3), el término árabe jubayz "malva" no corresponde al término romance "mirulyarqāra" y "mirliyāqarnārah", "corazonera". En cuanto a biyula parece ser "viñuela", que registra Maimónides (Glossaire 115), y que equi vale a Hayūfăriqūm hypericum, hierba del corazón". "Le nom espagnol viñuela désigne une petite vigne (Simonet 62); la forme- donnée par Simonet (2) est abobriella, et plus tard (61 et suiv.) "verba corazonera" [...] en espagnol moderne est corazoncillo. Les deux noms signi- 
mantecafresca de vaca derretida, aplica el producto resultante en clíster, dos o tres veces al día, porque el animal afectado de ahogo, asma o de cualquier infección interna, se alivia. ¡Permitalo Dios!

11. Sobre la hematuria en el animal.

Tritura excremento seco de hombre y ciérnelo, dáselo a tomar a continuación con agua caliente al animal y se curará. ¿Quiéralo Dios!

12. Sobre las verrugas.

Amasa harina de cebada con vinagre y aplica el producto resultante en untura sobre las verrugas, porque desaparecen. ;Permitalo Dios, El que indica el recto camino! [fol. 4 v.] 13. Sobre cómo extirpar los gusanos de las heridas.

Si escribes y después cuelgas en el cuello de la bestia la siguiente frase: "luqsi yuri ŷuq", los gusanos saldrán. Es cosa veraz y comprobada. ¡Permítalo Dios!

14. Sobre cómo elegir los días favorables del mes conforme opinión procedente de $\hat{Y} a^{\prime}$ far al-Șädiq ${ }^{39}$, quien a su vez lo tomó de los dichos de los antiguos maestros, que Dios tenga en Su santa gloria:

"El día primero de mes es favorable, porque Dios jalabado sea!, creó en él a nuestro padre Adán jla paz sea con él! Es apropiado también para visitar al sultán, llevar a cabo gestiones, viajes, ventas y compras. Quienes enfermen en él, recuperarán la salud rápidamente, ipermitalo Dios! Mas no conviene extraer la sangre en este día, porque quienes asi hagan, podrán contraer ictericia.

El día dos es asimismo favorable. Dios jalabado sea!, creó en él a Eva. Y él (Adán) se casó con ella en él, pues es buen día para la cama, viajar, vender, [fol. 5 r.] comprar y realizar todo tipo de gestión. Quienes en su principio enfermen, el mal será liviano, mas intenso a su término. Quienes se sangren, podrán contraer fiebres lo cual les alargará la enfermedad.

El día tercero es por completo nefasto. No visites al sultán, ni realices gestión alguna o encargo de aquél proveniente. Quienes emprendan viaje en él, se expondrán a perder los bienes y, quienes se sangren, pueden contraer albarazo.

El día cuarto es idóneo para casarse, ejecutar asuntos e ir de caza o pesca. Los nacidos este día serán amados y quienes emprendan viaje, serán alcanzados por ene-

fient herbe du coeur, sand doute á cause de la forme du fruit". En efecto, el "corazoncillo" (Hypericum perforatum) es una planta gutífera medicinal de hojas salpicadas de unas pequeñas glándulas traslúcidas y de manchas negras y con fruto acorazonado resinoso (María Moliner).

38. Se trata de otra receta mágica "verbal, escrita", que ya hemos indicado, aunque no podemos descifrar las voces escritas, cf. nota 29.

39. Cf. nota 7. 
mistad. Quienes enfermen, se recuperarán pronto, mas quienes se sangren, pueden sufrir muerte súbita siendo miércoles.

El día cinco es por completo nefasto, fatídico y desgraciado. Quienes en él se sangren, verán cubierto su rostro de tonalidad amarilla.

El día seis es por el contrario afortunado y a propósito para visitar al sultán, contraer matrimonio e ir de caza o de pesca. [fol. 5 v.] Quienes emprendan viaje, volverán sanos y salvos. Mas quienes se sangren, pueden padecer ebullición en la sangre.

El día séptimo es apropiado tanto para vender como para comprar, visitar al sultán, contraer matrimonio o efectuar cualquier gestión. Sin embargo, quienes en él se sangren, se teme que mueran.

El día octavo es favorable para ejecutar cualquier acto salvo viajar que es reprobable. Y, quienes en él se sangren, perderán las manos, la fuerza y la salud.

El día nueve es bueno y quien en él viaje, conseguirá bienes. Quienes en él enfermen, recuperarán la salud rápidamente, mas quienes se sangren pueden morir súbitamente.

El día décimo es idóneo. En él nació Noé, jla paz sea con él! Los nacidos en este día gozarán de vida cómoda y duradera. Quienes busquen en él cosa perdida, la hallarán. Los que en él enfermen, recuperarán pronto la salud. Es adecuado para negocios, y los que se sangren, no padecerán ni prúrigo ni sarna. [fol. 6 r.]

El día once es óptimo. En él nació Set, jla paz sea con él! Es día idóneo para visitar al sultán. Todos los que en él nazcan serán afortunados, porque tendrán riquezas y gozarán de larga vida. Sin embargo los que se sangren verán reducida su potencia sexual.

El día doce es también idóneo y afortunado para todo -como el anterior-. Quienes en él se sangren, mejorarán su hacienda.

El día trece es aciago por completo. No debe de realizarse por ello en él gestión alguna o encomienda del sultán. Quienes en él se sangren, pueden padecer gravidez cerebral. El día catorce es apropiado para llevar a cabo cualquier gestión. Los nacidos en él, serán personas de buenas costumbres, felices y amantes del saber, viendo incrementado su fortuna al término de sus vidas. Mas quienes en este día enfermen, pueden contraer un mal duradero y maligno. Y quienes se sangren adquirirán peso sin energía, y mejorará.

El día quince es favorable para realizar cualquier gestión. Sin embargo, los nacidos en él pueden morir. Y los que se sangren [fol. 6 v.] padecerán asma y debilidad. El día dieciséis es por completo nefasto. No se realizará por ello gestión alguna. Los que en él enfermen, morirán. Mas los nacidos en él, serán queridos, y los que se sangren estarán a

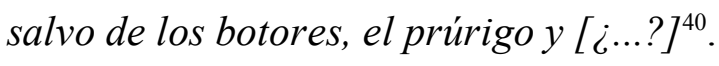

40. Voz ilegible. 
El día diecisiete es idóneo tanto para viajar como para llevar a cabo cualquier acto. Mas quienes en él emprendan litigio, pueden perderlo; y los que se sangren, pueden verse afectados por bilis negra, prúrigo o sarna.

El día diecinueve es bueno para todo. En este día nació Isaac, jla paz sea con él! Los nacidos en él se verán favorecidos, y los que se sangren no padecerán cólicos. [fol. $7 \mathrm{r}$.] El día veinte es idóneo para casarse y visitar al sultán. Quienes en él se sangren, no padecerán demencia ni elefantiasis.

El día veintiuno es nefasto por completo. Los nacidos en este día, sin embargo, serán afortunados. Quienes realicen viaje se arrepentirán, y quienes se sangren verán fortalecido el corazón y se enriquecerán.

El día veintidós es óptimo para vender y comprar. Los que en él nazcan gozarán de buena fortuna. Los que en este día enfermen recobrarán pronto la salud, y todo el que parta de viaje regresará felizmente. Quien trate con el sultán, encontrará bien y su petición recibirá favorable acogida, y los que se sangren, Dios les sacará afanes, calamidades, tristezas y pobreza.

El día veintitrés es feliz y afortunado, al igual que el día primero. Quienes en él se sangren [fol. 7 v.] recibirán de Dios vigor y coraje.

El día veinticuatro es nefasto por completo. En él nació Faraón, jmaldígalo Dios!, y los nacidos en él sólo hallarán reprensión en todo. Quienes emprendan viaje perecerán, y quienes en él se sangren tendrán buena angustia y mayor necesidad.

El día veinticinco es asimismo nefasto. Dios retiró las siete plagas a los egipcios. Quienes en él enfermen, no recobrarán la salud, y quienes se sangren, morirán. El día veintiséis es favorable para [i...? $]^{41}$. [fol. 8 v.]

[¿...?] Cuando se presente en su casa el dueño de la bestia, ésta se recuperará. ¡Permitalo Dios, alabado sea!

14. Otro procedimiento ${ }^{42}$.

Utiliza magia con el animal diciendo: "Un fuerte calor ha penetrado en Belén y lo ha querido afectar la despeadura”. Coge seguidamente siete pelos del rabo, únelos, haz en ellos siete nudos y átaselos, porque obtendrás buenos resultados, iquiéralo Dios!

15. Tratamiento para cualquier mal en las bestias y para curar el asma y el muermo.

Coge un cuarto de almud de centeno ${ }^{43}$, muélelo como la más fina harina y amásalo con levadura. Déjalo fermentar y haz de él un bollo tibio sobre la brasa, que

41. Las dos últimas líneas de la página y toda la página siguiente se hallan borradas por la humedad.

42. Receta mágica tomada de Ibn Hudayl, Tratado de Hipatría (fol. 133r). Cf. apartado Confrontación de las fuentes y nota 23 .

43.

No está claro a qué derivado del trigo designa el término sult. Maimónides (Glossaire 270) dice:

"Sult, orge nue ou épeautre. C'est une espèce inférieure de froment, qui ressemble be- 
retirarás del fuego antes de que se pase. Mígalo entonces en un recipiente [fol. 9 r.] y disuelve sus migajas con agua. Haz pasar el animal, dale a beber el agua resultante, porque lo limpiará de todo mal infeccioso que se haya cuajado en su interior o le aliviará de cualquier dolor. iPermítalo Dios!

16. Sobre la caída de las cerdas del copete.

Hipócrates dice: "El tratamiento para la caída de las cerdas del copete, es decir al-nuntin ${ }^{44}$, es como sigue: coge calabaza albarrana, raices de hinojo y de torvisco $[\dot{i} . . ?]^{45}$ días; al cuarto día, introduce en las fosas nasales de la bestia leche de cabra caliente aún del ordeño en la cantidad de dos onzas, y en los oídos, manteca de vaca derretida y cocida, porque se cura”. ¡Permitalo Dios! [fol. 9v.]

17. Sobre la sofocación interna en la bestia.

Hipócrates dice: "Una vez tendido el animal, haz una incisión en el vientre a dos dedos por debajo del ombligo con un canuto de cobre, y sacarás agua amarilla. Retira éste una vez salga espuma y golpea fuertemente con ambas manos la zona afectada.

Coge por otro lado, 1 arrate de alholva, 4 onzas de ajonjoli, 4 de granos de hinojo y 4 de semillas de col; 5 onzas de regaliz, 5 de malvavisco, 5 de semillas de melón y 5 de semillas de lino.

Muele bien todos los ingredientes, cúbrelos con agua, cuécelos de la forma adecuada, y añade, una vez que estén cocidos, 2 arrates de miel y 1 arrate de maliteca de vaca derretida. Finalmente da a tomar a la bestia [fol. 10r.] el producto resultante durante diez días, porque se cura”. ;Permítalo Dios!

aocup à l'orge. IB a identifié sult avec trágos de Dioscoride. Tuhfax l'identifie avec 'l'orge du Prophete'. Clément-Mullet (Ibn 'Awwām et J.A. Mars-Auril 1865 traduit sult par 'orge nue'). Dozy traduit, d'après le dictionnaire d'Alcalà (Granada 1506) sult par 'seigle' [...]”. Por otra parte, E. GARCíA SÁNCHEZ, Kitāb al-Agdiya (Tratado de los Alimentos) de Abū Marwān 'A Abd al-Malik b. Zuhr, Madrid, 1992 (p. 18- nota a) dice: "creo que, dentro de las variedades existentes del mijo, se trata del 'mijo perlado' (Pennisetum typhoideum Rich.) o variedad blanca, siguiendo la identificación propuesta por T. Lewicki en su exhaustivo trabajo West African Food in the Middle Ages, Cambridge, 1974, pp. 24-27”.

44. Este término aparece en el Tratado de Hipiatría de Ibn Hudayl (fol. 108x) escrito al-bus "desgracia, calamidad". Parece ser que nos hallamos ante un error de transmisión, por otra parte frecuente en textos científicos, donde el copista ha confundido el cuerpo de las letras, es decir, interpretó $s \bar{n} n$ por $t \bar{a}, y \bar{a}$ y $n \bar{u} n$; y $b \bar{a}$ por $n \bar{u} n$, de ahí $n \bar{u} t \bar{i} n$. Cf. mi trabajo realizado con Ma Teresa HERRERA, «Problemas en la transmisión de arabismos», al-Qantara, IV, 1 y 2, 1983, pp. 151-167. El texto de Ibn Hudayl dice así: "al-büs es la pérdida de pelo de la bestia por una alteración de la piel, que suele ir acompañada de comezón. Tiene su origen en la escasez y alteración de la sangre juntamente con carencia de vapores que nutren el pelo. Se ha de tratar en primer lugar reparando la sangre y engrosando al animal, posteriormente con este medicamento: raíz de calabaza albarrana y de torvisco". En suma, nuestro texto ha tomado de la fuente el dato pero mezcla y confunde las distintas recetas que el autor granadino aplica para esta enfermedad.

45. Texto corrupto por la humedad. 
Hipócrates dice también: "Si pones a macerar huevos enteros en vinagre, y cuando estén muy ablandados los introduces en la garganta del animal, éste se cura”. iPermítalo Dios!

18. Sobre las verrugas.

Hipócrates dice: "Pon sobre las verrugas localizadas en los oídos la untura elaborada a base de adelfa y sarcocola, bien molidas ambas y amasadas, sájalas seguidamente con un bisturí al rojo vivo y aquéllas desaparecerán totalmente”. ¡Quiéralo Dios!

19. Un aserto de Hipócrates:

"Si las verrugas se originan en otra zona del cuerpo no siendo su época, córtalas con el bisturí al rojo y aplica después sobre ellas vinagre hervido”. (fol. 10v.)

20. Sobre cómo tratar la salida del intestino.

Hipócrates dice: "Cuando se le sale el intestino al animal, efectúa un corte en su ano del tamaño de la uña, y aplica a continuación en la zona la untura cocida elaborada con 5 adarmes de sesbán, 5 de caldo de torvisco y 5 de alquitrán, y se lo metes adentro con las manos, colgándolo para evitar que el animal se tumbe, pues tanto al levantarse como al echarse puede correr gran peligro".

21. Sobre el tratamiento del animal debilitado.

Pon a macerar habas rojas hasta que se ablanden. Una vez maceradas, añade cebada al agua que bebe, porque éste engrosará. ¡Permítalo Dios!

22. Sobre la uña que se forma en los ojos de las bestias ${ }^{46}$.

[fol. 11r] Abre los ojos del animal e introduce en ellos una aguja de hierro, a fin de arrastrar con ella suavemente la uña hasta el borde del párpado, y después la sajas. Pon a continuación sal gema molida en los ojos.

23. Sobre la mancha blanca en los ojos de la bestia.

Hipócrates dice: "Haz primeramente una incisión en ambos lados de los ojos y echa la sangre en éstos. Pon después en los ojos, durante diez días, estiércol de camaleón molido con jibión ${ }^{47}$. Finalmente, aplica también en ellos semillas de hinojo una vez que las hayas masticado previamente en ayunas".

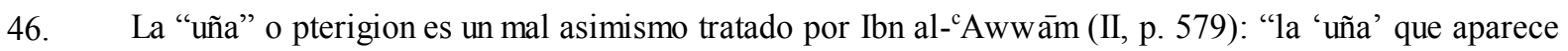
en el ojo de la bestia, y es una cosa añadida a su túnica a manera de película y que nace en los ángulos interiores del ojo próximos a la nariz, no dexa de ir en aumento de manera que agrandándose cubre la niña del ojo por los dos lados que están próximos a sus ángulos, y haciendo que cuelgue la uña cortes esta con herramienta". Cf. el apartado Confrontación de fuentes.

47. Identificamos el término en Maimónides (Glossaire 214): “Lisānn al bahrr) c'est aš-šibiyya (sepia) 'os de séche"”. 
Hipócrates dice: "Cuando la mancha blanca es transparente, coge granada dulce que previamente hayas envuelto en estopa y después enterrado en brasa caliente [fol. 11v.] para que se cueza. Luego la coges, abres y sacas su interior y se lo pones en los ojos de la bestia, cuanto pueda, véndaselo y sanará”. ¡Permítalo Dios!

24. Sobre las vejigas.

Hipócrates dice: "Sájalas, extrae por completo el líquido amarillo y seguidamente cauterízalas con miel de buena calidad y euforbio, porque las verrugas desaparecen". ¡Permitalo Dios, alabado sea!

25. Sobre cómo tratar al-malä'in, es decir, las adivas ${ }^{48}$.

Hipócrates afirma: "Una vez que las hayas extraído con el bisturi y las hayas extirpado de raíz, aplica sobre la zona afectada la untura elaborada con media onza de azufre y aceite cocidos, porque el animal se cura". ;Permitalo Dios!

26. Sobre el tratamiento de la carúncula o machacho ${ }^{49}$ sin fuego. [fol. 12r.]

Toma hojas de olivo, quémalas bien, retira la ceniza y rasura la zona objeto de tratamiento a navaja. A continuación aplica sobre ella aceite de oliva y la ceniza resultante, atándolo por encima, porque saldrá de raíz.

27. Sobre cómo tratar cualquier mal que afecte al casco del animal.

Hipócrates afirma: "Coge la cantidad del peso de 4 adarmes de incienso, y 4 adarmes de limaduras de cobre, 10 adarmes de vidrio, brea y grasa de cenizas alcali-

48. Al-Malācin es plural de mal $^{c}$ ūna "maldita". Enfermedad de las caballerías registrada por Ibn Hudayl (fol. $120 \mathrm{v}$ ), nombre vulgar, pues dice: "el cólico de vientre es llamado por el vulgo mal $^{c}$ üna, 'maldita', mientras que llaman al-diba, 'adivas' a la extirpación de la malignidad". El término romance "adivas" designa "cierta inflamación de la garganta de las caballerías" (María Moliner). Voz que proviene del árabe $a l-d \overline{\mathbf{N}} a$ (Eguilaz y Yanguas, Glosario Etimológico...). Ibn al- ${ }^{\mathrm{C} A w w}$ ām(II, p. 480) dice también: “Aristóteles dice, que el asno sobrecoge una particular enfermedad que le es perniciosa, y es un dolor que embargandola primero la cabeza, y después le fluye por las narices mucha flema de color bermejo la cual lo mata si llega a caerle en el pulmón. Según Aben Abí Hazám, una sola enfermedad ardiente acaece al asno, que es el $\operatorname{dibat}(a l-d \overline{\mathbf{N}} a)^{\prime}$.

49. Ibn al-'Awwām (II, p. 658) describe también este mal: "El machacho o carúncula (mašaš) acaece en la quartilla del bruto, en el nacimiento de su casco, en el tendón, en los nudillos y en la articulación y circunferencia de la rodilla. Unas veces es dura, y otras blanda que después se endurece [...] la carúncula (mašaš) a veces está en la mano [...] y a veces en el pie; y soliendo provenir de punzada de piedra, palo o cosa semejante que haya herido la mano, o de golpe o de cosa semejante, queda enervada y se hace un tumor a manera de nuez, menor o mayor que ella" (p. 664). Añade: "según los Greco-romanos, la carúncula es un tumor en el nacimiento del casco". Y en la página 664 se halla el antecedente de nuestro texto, porque dice: "Otro de Hipócrates el Veterinario en la operación de la carúncula sin fuego: toma unos cogollos de ramas de olivo con sus hojas y quemados cierne su ceniza, y rapando y untando después el sitio de la carúncula con alguna aceyte, ponle luego encima, segun su tamaño, un molde de heno seco de madera en forma de anillo en el que se haya puesto aquella ceniza, y atandoselo bien de suerte que no se aparte de aquel sitio, dexalo así una noche; pues secandole esto la raiz, quedará sano el bruto el resto de su vida, mediante Dios". 
nas, y 1/2 de arrate de aceite de oliva. Elabora con estos ingredientes un óleo y unge con él el casco de la bestia, porque los resultados son excelentes”. ¡Permitalo Dios!

28. Sobre la diarrea y el vómito de los niños. [fol. 12v.]

Si quemas cercillo de la copa de la vid, menta y apio, y das a tomar al niño la ceniza resultante, se cura. ;Permítalo Dios!

29. Un medicamento para la diarrea de los mayores.

La diarrea se cura con la ingestión de bayas de enebro. ¡Permítalo Dios!

30. Sobre el dolor que afecta a los ojos de los niños.

Si destilas en los ojos el medicamento que contiene asafétida tierna, humedad de cañas e incienso, y los disuelves en él y lo goteas en el ojo, se cura. ¡Permítalo Dios!

31. Un medicamento para la hernia testicular.

Si das a tomar mastuerzo, almáciga, cuajaleche y almidón, la hernia desaparece. ¡Permitalo Dios! Y se le prometerán nueces. Igualmente produce los mismos efectos el jugo de acederaque con mastuerzo. ;Permítalo Dios! [fol. 13r.]

32. Sobre el vómito.

Coge habb al-as, o sea, arrayán o murta, menta, almáciga y humedad de las puntas de las semillas de vid, cuece todo bien y da a tomar el producto resultante, porque el vómito cesa. ¡Permitalo Dios!

33. Sobre la evacuación de los humores del cerebro.

Toma los granos negros del trigo que los cristianos llaman "tayla", tritúralos, amásalos con aceite, e insúflalos con agua por un canuto. Que sean suaves, no los amases duros, entérate.

34. Sobre el feto muerto en el vientre de la madre.

Si la mujer se sienta sobre el vapor resultante de la cocción de la paja de cebada, el feto sale. ;Permítalo Dios!

Por otra parte, si la mujer se sienta sobre el vapor resultante de la cocción de quince hormigas, el feto será asimismo expulsado. ¡Quiéralo Dios! [fol. 13v.1]

35. Sobre la evacuación de los humores del cerebro.

Ofrece excelentes resultados espolvorear sobre la cabeza pimienta alumbre y carbón. ¡Permitalo Dios!

50. Acaso sea castellano "niella", "neguilla". 
36. Sobre el albarazo.

Toma el caldo resultante de la cocción de rubia, abdómenes molidos de cantáridas y vinagre. Mezcla todo y unge con el producto resultante la zona enferma, porque el mal desaparece. ¡Quiéralo Dios!

Otro procedimiento consiste en cauterizar -en la medida que el grosor de la piel lo permita-, hasta que la tonalidad blanca mude de color y desaparezca. Y aplicar seguidamente sobre la zona, la untura elaborada con harina de lentejas, óleo de rosas, hojas de llantén, es decir, "iblantayiin”, y sangre de vencejos, en la cantidad de una porción de cada uno, porque el albarazo desaparece. [fol. 14r.]

Otro procedimiento es como sigue: coge el arbusto denominado en romance "helecho" "5l, tritúralo, añade sal y vinagre, y después filtralo. Unge la zona afectada por el albarazo, porque éste se cura. Otro tratamiento es el siguiente: toma una serpiente de monte, córtala a cuatro dedos por debajo de la cabeza y de su cola. Pon la cabeza así seccionada en un recipiente nuevo, lleva éste al horno o directamente al fuego y déjalo hasta que se queme. Tritura la ceniza resultante y añádele vinagre fuerte. Empapa un paño de lana en el medicamento y frota con él, deforma adecuada, la zona enferma. Une por último ésta con miel y échale después los polvos elaborados con la serpiente. Si repites varias veces esta operación, las manchas blancas desaparecen. ¡Permítalo Dios!

Otro procedimiento, finalmente, asimismo efectivo para este mal consiste en aplicar sobre la zona afectada sangre de liebre. ;Permitalo Dios! [fol. 14v.]

37. Sobre la hinchazón en los huesos de los dedos del animal, es decir, masa o sobrehueso ${ }^{52}$.

El engrosamiento que se forma en los huesos de los dedos del animal o en sus pies se trata efectuando primeramente una pequeña incisión en la zona afectada sin insistir, luego coges sal y frotas muy bien; luego coges sal y frotas ajo y lo quiebras y lo vendas sobre él.

$Y$ en el labio inferior, dos son útiles para la flaccidez de encías, las úlceras, las ajuagas o las fístulas que pueden aquejar a la bestia.

38. Sobre la sangría de las venas situadas debajo de la lengua, indicada para curar la inflamación de la boca ${ }^{53}$.

51. Maimónides (Glossaire 226) registra falaya "helecho".

52. El "sobrehueso" es "un tumor que se forma en el hueso" (María Moliner). Asimismo Ibn Hudayl, Gala de Caballeros, blasón de paladines (pp. 116-117) dice: "si las cañas presentan una masa sin tener toda ella consistencia ósea, se dice que el caballo se amašš".

53. Tanto Ibn al- ${ }^{\mathrm{c}} \mathrm{Aww}$ ām (II, X y XI, p. 671) como Ibn Hudayl, Tratado de Hipiatría (fols. 116v a 119r) dedican sus dos capítulos a la sangría "de las venas que es costumbre corriente abrir, y sacar sangre de ellas, para curar a las bestias de sus enfermedades". Sin embargo una vez más el tratado morisco está incompleto y desordenado frente a la fuente árabe. 
Se han de sangrar a lo largo y no a lo ancho, dado que puede sobrevenir hemorragia de sangre dificil de parar.

39. Sobre la sangría de las arterias [fol. 15r.] de la sien, a propósito para la plétora cálida y mala que llega a los ojos.

40. Sobre la sangría de las venas occipitales próxima a la nuca, excelente para curar la obstrucción producida por sangre mala, y para calmar el dolor de cabeza localizado en la frente.

41. Sobre la sangría de las yugulares, indicada para el sofoco, el ahogo, el jarado y la calvicie. La sangría de la vena cefálica mitiga los dolores localizados entre la cabeza y las articulaciones del cuello.

42. Sobre la sangría de la basílica, que resulta a propósito para los males localizados por debajo del cuello hasta el vientre. [fol. 15v.]

43. Sobre la sangría de la vena media, útil para ambas cosas, útil para todo lo que la basilica.

44. Sobre el torzón en los caballos, es decir, el dolor de vientre.

Si coges una caña dura, la sumerges en aceite de oliva y la pones en el orificio por donde orina el animal, éste se cura. ¡Quiéralo Dios!

45. Sobre la uña en el animal.

Cuando el animal es afectado por la uña en sus ojos que los cristianos llaman "ungula", introduce en ellos una aguja de hierro y arrastra la excrecencia hasta el borde. Espolvorea a continuación en los ojos sal gema, es decir, sal pedrés y nitro, molidos, porque el animal se cura. ¡Permítalo Dios!

46. Sobre el lobado ${ }^{54}$.

Si quieres curar a la bestia de la enfermedad que los cristianos llaman "lobado" [fol. 16r.] coge un hierro calentado al rojo y cauterízalo de través, porque si así no haces, el animal morirá a los tres días. Es cosa eficaz y experimentada.

47. Sobre cómo tratar sin fuego las vejigas en el animal.

Coge lana forrada y sangra la vena pulsátil situada entre el dedo índice y el corazón; es bueno para el dolor de bazo.

54. 'El 'lobado' es un tumor carbuncoso que les sale a las caballerías en las axilas y a las vacas, cabras y ovejas en las axilas y en la papada" (María Moliner). Ibn al- ${ }^{\mathrm{A}}$ Awwām trata también este mal (II, pp. 595 y 603): "Quando el lobado ( $a l-d \overline{\mathbf{N}} v a)$ aparece en el cuello, en las orejas, en la vena yugular exterior, o en el pecho del bruto, las señas de esto es si vieres que se le ha inflamado ya la garganta y el pecho, y que rehusa el pienso". 
En cuanto al prúrigo y las úlceras en los oídos, resulta excelente sangrar la vena pulsátil de la rodilla, donde está la safena arriba del pulgar, en el interior de la pantorrilla. Para las llagas de los pies, sangrar la ciática de su mal, es decir, al dorso de la pierna.

48. Sobre el cólico de las caballerías que los doctores llaman "torzón" "55.

Se conoce por experimentación el siguiente procedimiento: escribe [fol. 16v.] en los cascos del animal las siguientes palabras: a la derecha, "s.ayh" y a la izquierda "s.ayh", a la derecha, "daŷlah" y a la izquierda "furat": es cosa cierta y probadas6.

49. Sobre las heridas con inflamación.

Coge cebolla y sal, machaca todo, y ponlo sobre la herida enconada, que la quitará de raíz y pondrás dentro agua caliente y comino. A continuación pones vísceras de polluelo calientes con un poco de aceite ( $(. . . . ?]^{57}$, luego déjalo un rato y mide cuatro dedos del ombligo del animal, y coges un hierro candente y aplicalo según tu estima y mantenlo un rato, porque se cura. ;Permítalo Dios!

50. Sobre la inflamación de párpados o barba ${ }^{58}$. [fol. 17r.]

Hipócrates afirma: "En cuando a la inflamación de párpados, toma serrín", tritúlalo bien y mezcla y añade miel, sal y vinagre, y aplica el producto resultante sobre la zona puesto sobre un un bastón y un trapo".

51. Sobre al-kuhabun, es decir, muermo ${ }^{60}$.

Hipócrates dice: "Coge tres huevos, ponlos en un recipiente y añade vinagre en una cantidad que los cubra. Déjalos en maceración dos o tres días, hasta que el vinagre pele la superficie. Luego abre la boca de la bestia e introduce, por último, los huevos en la garganta del animal, porque éste hallará beneficio”. ‘Quiéralo Dios!

55. También TOROZON, "Torcijón, Torzón. Cólico de las caballerías que les produce dolores espasmódicos" (María Moliner). "Retortijón doloroso del vientre, torozón” (Diccionario de la Lengua Española Vigésimo primera edición).

56. Cf. nota 29. En cuanto a los nombres citados acaso haya que entender que el autor se refiere a la antigua tradición islámica de que cuatro son los ríos del Paraíso, el Nilo, El Eúfrates, Sayh ūn y Ŷayhun. Cf. Yaqūt al-lūmī, Mu'yam al-Buldān”, Beirut, 1979, IV (p. 242). Porque al río Eúfrates se le reconocen numerosas propiedades extraordinarias, como curaciones de enfermedades, entre otras.

57. Hueco en el texto.

58. El término romance "barba" es aquí "carúncula", "cualquier pequeña excrecencia carnosa" (María Moliner).

59. No documentamos manāšir. Lo hemos interpretado como una deformación de nušāra, "serrín", virutas".

60. No documentamos el vocablo árabe, kuhābun. En cuanto a armū, parece ser una deformación de "muermo", que el mismo texto cita más adelante, enfermedad equivalente a junāqiyya, es decir, "una enfermedad de las caballerías, transmisible al hombre, que consiste en una ulceración de las mucosas de la nariz e inflamación de los ganglios próximos” (María Moliner). 
52. Sobre la mancha blanca en los ojos de la bestia.

Ésta desaparece si introduces en los ojos del animal, dos veces al día, excremento de lagarto y sal, molidos y después tamizados, [fol. 17v.] pues disuelve el tegumento, si Dios quiere, cierto y probado.

53. Sobre cómo eliminar el higo ${ }^{61}$ que afecta a las bestias.

Coge semillas de la hierba llamada "arzaquzvāhušti ${ }^{62}$ " y cuelga ésta durante nueve dias en el cuello del animal que padece este mal, porque se cura. ¡Permítalo Dios! Es cosa cierta y probada por experimentación.

54. Sobre cómo tratar la viruela y las ajuagas localizadas en las patas del animal.

Coge un poco de malva, salvado y grasa de carnero. Cuécelos, toma el producto resultante y dáselo, o sea, frótalo y sácale el agua que contiene y ráelo por dentro hasta llegar al hueso. [fol. 18r.] Aplica después sobre la zona albayalde seco, acíbar socrotino y alquitrán, una vez hayan sido amalgamados sobre el fuego, porque el animal se cura. ¡Permitalo Dios!

55. Sobre cómo tratar la sentadura o excoriación de los huesos del lomo ${ }^{63}$.

Hipócrates dice: "Cuando haya sido almohazado [el animal], aplica masaje sobre la zona afectada con agua caliente a fin de calmar el dolor. Cuece a continuación miel de buena calidad y euforbio, y raspa aquélla con la navaja. Pon, por otra parte, los medicamentos mencionados en un recipiente y échales sal envuelta en un paño, que mejorarás en el medicamento hirviente, y aplica el producto resultante sobre la zona almohazada. Da masaje finalmente, porque el animal se curará”. ;Permitalo Dios!

56. Sobre el dolor de hombro o contorcimiento ${ }^{64}$. [fol. 18v.]

Hipócrates afirma: "Coge y pon en el suelo el animal y toma el agua que sale de la lesión, amasa ésta con 'așìda de cebada y pon el producto resultante sobre la

61. El "higo" es "una excrecencia generalmente de origen venéreo, que se forma alrededor del ano" (María Moliner).

62. Desconocemos este término.

63. La "sentadura" es "una señal o herida en la carne por una cosa que se le incrusta [...] o que roza o aprieta; por ejemplo, la que les hace a veces la albarda a las caballerías" (María Moliner). Ibn al-'Awwān (II, p. 602) registra, entre "las enfermedades y achaques que acaecen en el cuerpo del bruto, la 'matadura'; la qual consiste en que en el encuentro de las espaldas del bruto, en su cruz, en la extensión de aquellas y en su lomo mana sangre por la lesión de la silla, por excoriación de la albarda, y por otras causas [...] la más perjudicial de este género es la que acaece en el encuentro de las espaldas del bruto".

64. El término romance parece referirse a la "contorsión" o "descoyuntarse", "dislocar", "desencajar un hueso de su articulación" (María Moliner).

65. Papilla de harina de trigo, cocida en un potaje de verduras frescas. R. ARIÈ, España Musulmana, vol. III de Historia de España de Turón de Lara, Barcelona, 1983, p. 284. Cf. el apartado Comentario filológico. 
zona, porque tanto el ahogo como la inflamación que se suscite en cualquier parte del cuerpo desaparecerán”. ¡Permítalo Dios!

Si es intenso el sofoco y abrasa a la bestia, coge harina de trigo, ciérnela y coge lo que sea más fino y sutil, amásalo con agua de retama blanca y ponlo como se ha dicho con la cebada, siendo el reposo siete días.

Un aserto de Hipócrates: "Si el mal es benigno, su tratamiento será de siete días, aplicando greda blanca al animal, porque se cura”. ¡Permítalo Dios!

57. Hipócrates afirma: [fol. 19r.]

"Sobre el tratamiento de la vena del cuello que afecta al acromio.

Este mal es una vena que se llena de varices -lo peor que afecta al hombro-, que produce una sensación permanente que desciende por huesos y venas, y que únicamente dura hasta el momento en que lo vendas con alcachofa blanca con su raíz si está seca, teniendo en cuenta que si esta fuere tierna, sus resultados son todavía mejores: si la encuentras debes de molerla bien, hervirla y después aplicarla sobre la zona, porque desaparece el tumor". ¡Permitalo Dios!

58. Sobre la aplicación del clister al animal ${ }^{66}$.

Hipócrates dice: "El clíster es uno de los mejores tratamientos, en primavera tanto para eliminar en el animal los gases internos como las distintas humedades capaces de generar sofocación o la calidez del ahogo". [fol. 19v]

Has de saber asimismo que también está indicado para el ahogo y el asma, porque lo erradica junto con su ardor y picor, aclara el color, engrosa el cuerpo y liquida cualquier mal o dolor".

59. Un aserto de Hipócrates:

"Si deseas que el clíster sea de jugo de aceituna y retama, durante diez días seguidos, añade miel al agua, bate todo y aplica el clister de la forma previamente mencionada".

60. Sobre el animal sarnoso, es decir, la sarna.

Hipócrates afirma: "Coge calabaza albarrana, córtala en trozos pequeños y cuécela en aceite de oliva. Toma éste y añádele [fol. 20r.] 3 arrates de alheña, 3 de onzas de pimienta y 3 cabezas de ajo. Aplica en untura el producto resultante al animal,

66. El antecedente de este capítulo se halla en Ibn Hudayl (fol. 123v) que dice: "El clíster resulta beneficioso para el animal cuando sus lames son internos, como la eliminación de los gases, las humedades de la sofocación y la calidez del ahogo. El mejor momento (de aplicación) es en el estío; se usará en primavera para (tratar) todos los males de la espalda, del movimiento y el cólico y la caída del pelo, a la vez que aclara el color y engrosa y fortalece el cuerpo. ¿Quiéralo Dios! Un clíster seguro y excelente es el de jugo de aceituna aplicado durante tres días seguidos". Es posible por tanto que la expresión de nuestro texto: "wa-yuzcayisaha wa-hardilha wa-hakatah $\vec{a}$ " (porque la erradica junto con su ardor y picor), sea una lectura errónea de al-büs (caída del pelo), al-ẓahr y al-haraka (espalda y movimiento). 
templado, cada día, porque se cura. ¡Permítalo Dios!. Es un medicamento asimismo beneficioso para el hombre".

61. Un aserto de Hipócrates:

"Para el sobrehueso, la carúncula, la hinchazón, el tumor, la sarna, la mancha blanca y el dolor resulta excelente la cebolla albarrana”. ¡Permitalo Dios!

62. Sobre el incienso.

Tritura el incienso, introdúcelo en un canuto de caña y efectúa insuflaciones tanto en la nariz como en las sienes, tres veces al día. Luego retíralo, y coge por otra parte un trozo de piel de zapato de la misma medida que la carúncula, y carne salada de la parte delgada del cerdo [fol. 20v.] que los cristianos llaman "anca". Por otro, toma semillas de fenol, mastícalas bien y ponlas en los ojos del animal juntamente con sal gema, es decir, sal pedrés, molida, porque se cura. ;Permítalo Dios!

63. Sobre cómo detener la hemorragia nasal.

Mete gusanos de estercolero en el horno hasta que se quemen, muélelos y ponlos en las fosas nasales, porque la hemorragia cesará. ¡Permítalo Dios!

64. Sobre el crecimiento del pelo en cualquier parte del cuerpo.

Calcina huesos de dátil, es decir su nuez, tritúralos y amásalos con óleo de rosa. Aplica el producto resultante, en untura, sobre la zona donde quieras que salga el pelo. ¡Permítalo Dios!

65. Sobre cualquier clase de herida, mordedura de perro o contusión producida por espada o piedra.

Pon una lámina de cobre sobre la zona a tratar y venda [fol. 21r.] deforma que no se desate, porque no se producirá ni tumefacción ni inflamación alguna. ¡Permítalo Dios!

66. Sobre la disuria.

Coge ceniza de lentisco, échale agua, muévela y déjala hasta que se aclare, y después filtrala. Coge seguidamente la cantidad de tres huevos del agua resultante, añádele aceite dulce de buena calidad en la cantidad que lleva una cáscara de huevo y bátelo. Quémalo y da a tomar el producto resultante a quien padezca disuria, porque orinará al momento. Es cosa probada.

67. Sobre la sarna.

Coge hojas verdes de adelfa que es al-baladr $\mathbf{1}^{7}$, machácalas bien y ponlas en un recipiente sin usar. Llena éste de agua y añade un poco de brea, medio arrate de

67.

Entendemos que al-baladrī es la forma romance "baladre", "adelfa" (arag. murc. alm., del catalán "baladre") según Corominas, Font Quer (p. 732) dice: "Nerium oleander, se cría en las ram- 
grasa, dos onzas de azufre, cinco [fol. 21 v.] granos de ruibarbo ${ }^{68}$, que los cristianos llaman "rabüntinum", y una pizca de coriandro verde. Pon todo a hervir, y cuando el agua haya tomado tonalidad oscura por disolverse la grasa y la brea, retira el recipiente del fuego y déjalo enfriar. Pon después el contenido del recipiente en una sartén con aceite de oliva. Aplica finalmente el producto resultante en untura sobre la zona afectada por la sarna, una vez que lo hayas calentado ya al fuego, ya al sol, porque ésta desaparece. ;Permítalo Dios! 68. Sobre las escrófulas ${ }^{70}$.

Coge una culebra, corta la cabeza y la cola, ábrela por el vientre y aplícala sobre la zona afectada por las escrófulas, porque los gusanos saldrán adheridos a ella.

Si con esto no bastara, vuelve a repetir la operación, mas aplicando esta vez sobre la herida cebolla blanca, dado que ofrece también excelentes resultados. ;Permítalo Dios!

69. Sobre las heridas con gusanos. [fol. 22r.]

Coge las hojas de melocotonero, muélelas bien y ponlas en una cebolla. Aplica ésta sobre la herida, porque los gusanos saldrán. ¡Con el permiso de Dios!

70. Sobre las sanguijuelas localizadas en la nariz o en la boca.

Toma una caña de habas seca, quémala, pon la ceniza resultante en un canuto de caña y haz insuflaciones por la nariz o la boca del animal, porque las sanguijuelas se desprenderán. ¡Permitalo Dios!

71. Sobre las verrugas.

Coge una vara de sarmiento verde, ponla al fuego, y una vez que suelte el jugo, unge con él las verrugas, porque desaparecerán. ¡Permítalo Dios!

También desaparecen las verrugas si pones sobre ellas harina de trigo amasada con vinagre.

72. Sobre el enrojecimiento de los ojos.

Coge litargirio, tritúralo, tamizalo, añádele leche de mujer que amamanta a una criatura y aplica el producto resultante alrededor [fol. 22v.] de los ojos, porque el enrojecimiento desaparece. ¡Permítalo Dios!

blas y a las orillas de las corrientes de agua de tierra baja, desde las cercanías del Ebro hasta el Alentejo, en Portugal. Este arbusto constituye el mejor ornamento de los barrancos de Sierra Morena, donde vive en gran profusión, y de muchos torrentes del litoral mediterráneo".

68. El texto dice "rand", "laurel", entendemos que por confusión con "räwand", "ruibarbo" (Rheu barbarum).

69. Rabūtinum, "rapóneligo" (Campanula rapunculus). Sin. cast. ruipóntico, ruipóntigo, ruiponce. En latín medieval, radix pontia, rapontium, rapuncium (Font Quer, p. 774).

70. Cf. el apartado Confrontación de las fuentes. 
73. Sobre las lombrices intestinales.

Pon a quemar ajos desprovistos de piel, y da a tomar en ayunas la ceniza resultante, porque las lombrices saldrán inmediatamente. ¡Permítalo Dios!

74. Sobre la inflamación de testículos, es decir, los cojones.

Si mueles acelgas de buena calidad, las amasas con miel y las pones sobre los testículos, la inflamación desaparece. iPermitalo Dios!

75. Sobre los beneficios que la alholva reporta a las bestias.

Hipócrates afirma: "La alholva resulta beneficiosa para los males internos del animal, para el estómago, para el intestino y para la inapetencia, a la vez que también evita la sequedad de las heces y la retención de los gases.

La forma de su preparación es: cuécela bien, añádele un arrate de manteca de vaca derretida o de aceite de almendra, y una onza de aceite de nuez y de óleo de rosa. [fol. 23r.] Da a tomar el producto resultante durante tres días, porque con ello será suficiente para que se produzcan los beneficios indicados". ;Permítalo Dios!

76. Un aserto de Hipócrates:

"Para que el animal engrose, macera día y noche en agua para que se ablande, beleño cortado en trozos y cebada. Coge después el agua, frótalo con ella y echa la cebada al pienso, porque el bruto adquirirá peso”. ¡Permítalo Dios!

77. Sobre la despeadura o empedradura.

Hipócrates afirma: "Coge grasa de cerdo, óleo fresco de lino, estafisagria, albayalde y azufre. Muele todo, lleva el producto resultante al fitiego con aceite de oliva hasta que se fría bien. Unge seguidamente al animal con el medicamento de este modo confeccionado, porque se cura”. 'Permitalo Dios! [fol. 23v.]

78. Sobre el dájaso o clavo pasado ${ }^{71}$.

Hipócrates dice: "Coge siete adarmes de miel de buena calidad, makma y masma ${ }^{72}$, y raices de olmo negro. Mezcla todo y aplica el producto resultante en untura sobre la zona objeto de tratamiento. Mas extrae al mismo tiempo, por otra parte, dos arrates de sangre, en cada mano, de la vena del antebrazo, porque el animal se cura”. ;Permítalo Dios!

79. Un aserto de Hipócrates:

"Las hemorroides y el prúrigo se tratan lavando, en primer lugar, con el agua resultante de la cocción de lana áspera y de la raíz del peral, previamente trituradas

71. Cf. nota 6 .

72. Acaso ambos vocablos se refieran por deformación a la "masmacora" o "calabazuela", Maimónides (Glossaire 133). 
y cocidas en agua, frotando bien a fondo. Mas no apliques este tratamiento si el día es frío, sino caliente, unge con aceite de oliva y ceniza, pero cuidando siempre que el frío no perjudique, porque se curarán”. ¡Permítalo Dios!

80. Sobre la extracción de los dientes sin herramienta. [fol. 24r.]

Los dientes se salen si aplicas en ellos la ceniza resultante de la combustión de albayalde.

Otro procedimiento: coge la planta que en romance se llama "coloquíntida", tritúrala con vinagre hasta adquirir la contextura de la miel y aplica el producto resultante sobre parte de la encía que rodea al diente, hasta sangrar. Unta también después con el mismo producto, dos o tres veces, alrededor del marfil, porque el diente saldrá fácilmente con la mano, sin emplear instrumento alguno. ¡Permítalo Dios!

81. Sobre las sanguijuelas localizadas en la garganta.

Las sanguijuelas se alzan y caen de la garganta al humo de haber quemado chinches en la brasa.

Otro sistema es atar a una varilla un trozo de piel de carnero o de cualquier otro animal sin curtir y poner ésta donde están las sanguijuelas, porque saldrán todas adheridas a la piel. Es cosa probada y cierta [fol. 24v.]

82. Sobre la extracción de astillas, huesos o espinas en cualquier parte del cuerpo.

Las astillas salen si pones sobre la zona donde estén localizadas el emplasto de manteca de vaca derretida.

83. Sobre el crecimiento del pelo.

Si coges trigo y hojas de arrayán, es decir, murta, los trituras con óleo y aceite de oliva, y aplicas en untura el producto resultante sobre la zona, el pelo aumentará y engrosará.

84. Sobre la sarna.

Coge un puñado de espino albar y otro de apio y de cerraja, cuécelos en agua y lava bien las zonas en las que esté localizada la sarna, de forma que se ablanden. Unta después éstas, durante tres dias, con aceite en que hayas disuelto litargirio, [fol. 25r.], porque la sarna desaparece por completo. ¡Permitalo Dios!

85. Sobre la picadura producida por escorpión, reptil o cualquier otro animal venenoso.

El veneno sale si vendas la zona afectada con levadura de la masa del trigo a la que se le haya añadido vinagre.

86. Sobre las ajuagas en los talones.

Coge cáscaras de berenjena, hiérvelas en aceite de oliva hasta que se doren, filtra el aceite en un recipiente limpio y añade un poco de brea y cera hasta engrosar. 
Aplica seguidamente el producto resultante, en untura, porque las grietas desaparecen. ¡Permítalo Dios!

87. Sobre cómo abrir el tumor duro.

Muele rábano seco hasta volverse polvo, amásalo con jabón, y aplica el producto resultante en emplasto sobre la inflamación, porque ésta se abre. iPermítalo Dios!

88. Sobre la cicatrización de la contusión producida por [fol. 25v.] espada o cuchillo.

Si calcinas y trituras el extremo de un zapato o del cuerno del ciervo o del cuerno de cualquier otro animal, y espolvoreas después la ceniza resultante sobre la zona afectada, la herida se cierra. ¡Permítalo Dios!

89. Sobre el tumor duro.

La inflamación desaparece si pones sobre ella telas de araña empapadas en aceite de oliva cuanto tolere. ¡Permitalo Dios!.

Otro procedimiento es el siguiente: amasa higos lambadar ${ }^{73}$ con sal y aceite de oliva, y aplica el producto resultante sobre la zona, porque la inflamación desaparece. iPermítalo Dios!

90. Sobre la enfermedad de la espina ${ }^{74}$.

Resulta beneficioso aplicar en untura sobre la zona, cardenillo, miel, vinagre y azogue. O poner sobre ella rejaljar y parietaria, el cual está asimismo indicado para las úlceras con mal aspecto. ;Dios es El que concede el recto camino! [fol. 26r.]

91. Sobre la mordedura del perro rabioso.

Muerde muchas veces trigo y ponlo sobre la zona pues saca el veneno. ¡Permítalo Dios!

92. Sobre cómo eliminar la hinchazón de las piernas.

La inflamación de las piernas desaparece si untas éstas con el óleo elaborado a base de salvia, azogue y grasa de cerdo machacadas. ;Permítalo Dios!

93. Un ungüento indicado para las ajuagas en las patas del animal.

73. Clase de higos, probablemente de Málaga según nos informa F. Corriente.

74. Se trata de una "úlcera muy dolorosa generalmente en el pulgar" (Dozy, Suppl.). También registra esta enfermedad Muhammad al-Šafrā (Kitab al-Istiqsā) (Tesis Doctoral, Universidad de Granada, E. Llavero, 1988, I. p. 135), quien al hablar del panadizo y de su tratamiento expone: "si te descuidaras en su tratamiento y llegase la corrupción al hueso, entonces será difícil su tratamiento, conociéndose esta enfermedad como enfermedad de la espina". 
Toma azufre, cardenillo, almartaca, alheña y vinagre, tritura todo y hierve el producto resultante al fuego. Unge con él y con aceite de oliva las hendiduras que semejantes a las grietas tiene el animal. Es cosa probada. [fol. 26v.]

94. Sobre cómo conocer los signos de la sangre.

Si la sangre es negra, deja que enrojezca. Si espesa, que emane y adelgace. Por el contrario, si es aguda, evita su agudeza.

95. Sobre cómo cerrar las heridas con hilo.

Coge al-šayān, que en romance se llama "sangre de dragón" "75 e incienso. Haz unos polvos y échalos sobre la herida y cósela, porque cerrará y curará. ¡Permítalo Dios! Aplica seguidamente sobre la herida los ungüentos cicatrizantes, y déjalos apretados dos o tres días, porque curará por completo. ¡Permítalo Dios!

96. Sobre la inflamación de las venas por sangría.

Pon una esponja de mar empapada en agua razonadamente caliente y sal sobre la vena inflamada [fol. 27r.], porque la inflamación desaparece.

97. Sobre cómo tratar el chancro, es decir, la enfermedad que los cristianos llaman "manchas", es decir, fístula.

Elabora una masa con harina de cebada, miel y sal. Introduce ésta en un canuto de caña que pondrás sobre las ascuas hasta calcinarse. Sácalo y lava seguidamente la fístula con miel, y después espolvorea sobre ella la ceniza resultante de la calcinación de la caña, porque se curará. ¡Permítalo Dios!

98. Sobre cómo detener la hemorragia nasal.

Calcina por un lado unta pluma de ave. Por otro, muele cáscaras de huevo y zumaque. Cierne todo por el tamiz y finalmente haz insuflaciones en la nariz por un canuto de caña con el polvo resultante, porque la hemorragia cesará. ¡Permítalo Dios! [fol. 27v.] Otro procedimiento consiste también en poner en la nariz, juntamente con los polvos antes mencionados, alquitrán y resina, o sólo estos dos, porque la hemorragia también cesa. ¿Quiéralo Dios!

99. Sobre la mancha blanca en los ojos de la bestia.

Cuece vidrio, pásalo por el tamiz y espolvoréalo en los ojos de animal. Muele a continuación toronjil ${ }^{76}$ e hinojo con un poco de vinagre que le eches, prénsalos y echa

75. "Resina de la palmera de drago, que es de color rojo; se emplea en farmacia como astringente" (María Moliner).

76. Desconocemos si al-bädir es una deformación de bādranŷȳùa, Mellisa officinalis, "toronjil"; de bādāward, "Onopordon acanthium", "cardo borriquero"; o incluso bādār $\bar{u} \hat{y}$, "albahaca" (Ocimum basilicum). 
por último el líquido resultante en los ojos, porque la mancha desaparece. ¡Permítalo Dios! 100. Sobre las vejigas.

Toma grasa de cerdo y disuélvela bien, empapa con ella lana sucia y pon ésta sobre la vejiga, en la medida que el animal lo tolere, porque desaparecerá al cabo de dos o tres aplicaciones. [fol. 28r.]

101. Sobre la verruga o gabarro ${ }^{77}$.

Saja desde la raíz con un hierro como la misma cuchilla de zapatero, que pondrás en la misma cabeza de la verruga. Espolvorea después con polvos de arsénico, es decir, oropimenta, porque se cura. ¡Quiéralo Dios!

102. Sobre cómo curar sin fuego las vejigas que produce el animal.

Abre una cebolla blanca o roja y pon en ella, abriéndola un poco, bastante cantidad de sal. Aplica después esta sobre las vejigas, desde la tarde hasta la mañana del día siguiente, porque desaparecen. Es cosa cierta y probada.

103. Sobre el tratamiento del esparaván en el animal.

El mejor tratamiento para este mal es la cauterización cruzada, la cual igualmente está indicada para la hinchazón [fol. 28v.] que los cristianos llaman "sobrehueso”, porque así lo afirma Hipócrates, excelente médico, diciendo: "La cauterización es el final de la medicina".

104. Sobre el animal despeado ${ }^{78}$.

Si aplicas cada día sobre la mano o el pie del animal que se ha despeado, bledo y miel, hervidos por separado, se cura.

105. Sobre la herida en el animal cuando en la marcha alcanzan las patas traseras las delanteras.

Si calientas en el fuego cortezas de cerdo y las pones sobre la herida, o procedes de igual manera con la corteza caliente del queso añejo, el animal se cura. ¿Quiéralo Dios!

106. Sobre la mancha blanca en los ojos de la bestia. [fol. 29r.]

Si pones hiel de culebra disuelta en leche de asna y jugo de llantén en los ojos de la bestia, la mancha blanca desaparece por completo.

77. "Gabarro" es una "especie de úlcera que pueden tener las caballerías en el casco". Kabarro, "gabarro", enfermedad del ganado "clavo" (cat. cavarrot "tachuela") (DCECH, Corominas).

78. "Despeadura, despeamiento, despeo". "Acción de despearse. Estropearse los pies las personas o los

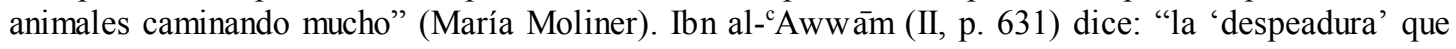
acaece en los cascos del bruto consiste en que se halle alguno lacerado, y lo haya gastado la tierra". 
107. Sobre el tratamiento de la cavidad que sale en la zona comprendida entre la uña y la carne.

Pon, el primer día, en la zona afectada clara de huevo con sal pedrés. El segundo, yema de huevo cocida con grasa de cerdo, dos días o más. Si con esto no se cura o seca, aplica sobre la herida una estopa impregnada con agalla, es decir qälah, una vez molida, tamizada y posteriormente hervida en vino y aceite de oliva, porque el mal desaparece.

108. Hipócrates dice:

"Si tratas esta enfermedad con brea sin dañar los lugares que sean de carne y lo pondrás en el sitio y lo dejarás en él hasta el segundo día, [fol. 29v.] a la vez que impedirás que el animal se introduzca en el agua durante siete días, se cura".

Otro tratamiento además de los mencionados para curar tanto esta enfermedad como mejor aún el sobrehueso, se basa en el empleo de ajos y pimientos.

109. Sobre la sofocación.

Muele caracol, añade grasa de cerdo, albayalde y vino aromático. Utiliza el producto resultante dándoselo al animal tanto por vía oral como por vía nasal. Es cosa cierta y probada.

110. Sobre la mancha blanca o lepra.

Toma un hilo de seda y átalo a su raíz. Frota por otro lado los hombros con el agua que haya hervido con camomila y efectúa seguidamente insuflaciones por un canuto hasta [fol. 30r.] que se levante de soplar. A continuación saja la hinchazón con el escalpelo o con el escarificador.

Toma después unos adarmes de euforbio y cuécelos en un arrate de aceite de oliva hirviendo. Confecciona a continuación una traba pequeña, de la medida de un palmo, y traba la mano sana con el pie enfermo durante siete días. Unge por último la zona afectada con manteca de vaca derretida, porque la enfermedad desaparece. ¡Permítalo Dios!

111. Sobre la viruela o salpullido.

Hipócrates afirma: "El tratamiento del salpullido que va acompañado de hinchazón $y$ de transformación, que afecta igualmente tanto al ganado vacuno como al cabruno, es como sigue: coge lejía, cebolla albarrana y aceite de oliva añejo. Cuece todo en un recipiente nuevo con aceite de oliva, hasta que se dore la cebolla. Añade cal al aceite de la cocción, mezcla bien todo y unge por último la zona objeto de tratamiento con el producto resultante, porque el mal desaparece. iPermitalo Dios!

112. Sobre el tratamiento de la viruela en las ovejas.

Dice asimismo Hipócrates: "Coge aceite de laurel y de almendras amargas, tríaca, manteca de vaca derretida, limaduras de cobre y hollin; 3 onzas de cardenillo $y$ de arsénico, [fol. 30v.] es decir, urbimintu; y medio arrate de miel. Cuece los medi- 
camentos, elabora un óleo con el cual ungirás tanto las ajuagas como la zona del cuerpo afectada por la viruela, porque resulta excelente. ¡Permítalo Dios!

113. Sobre cómo detener la hemorragia de sangre de las heridas.

Pon sobre la herida un paño de lino empapado en agua fría que dejarás hasta que la sangre deje de manar. Si con esto no fuere suficiente, espolvorea sobre la herida tierra de Sevilla molida con aceite de oliva y agalla, después venda con un paño durante dos o tres dias, porque la sangre cesará de manar. ¡Permítalo Dios!

Otro procedimiento: aplica sobre la zona inflamada por sangría o por contusión un paño empapado en vino y óleo de rosa, [fol. 31r.] porque la inflamación desaparece.

Resulta excelente, por otra parte, si la inflamación va acompañada de dolor intenso, poner sobre la zona lana sucia empapada en vinagre y aceite de oliva. ¡Quiéralo Dios!

114. Sobre la curación de las heridas.

Coge 3 onzas de almáciga, 2 arrates de aceite de oliva, 1 arrate de vinagre concentrado y 2 onzas de lo que en romance se llama "ištuqdārān" ". Confecciona un óleo con todo ello, porque la herida cura y seca. ¡Permítalo Dios!

115. Sobre la inflamación de la boca de las caballerías como consecuencia de los molares, contusión, madera, piedra o por coz de una bestia.

Tritura ajenjo amargo, que en otra lengua se llama "doncella", y morela, que en romance se denomina "mirulyāraqārāo mirulyaqarnārah" "80 [fol. 31v.] con grasa de cerdo. Añade un poco de miel, aceite de oliva y harina de trigo. Cuece cada ingrediente por separado y aplica el producto resultante sobre un paño que pondrás sobre la zona objeto de tratamiento, tres o cuatro veces al día, según se aguante.

Existe asimismo otro procedimiento que se basa en lo siguiente: cuece jugo de doncella y de apio, brea, grasa de cerdo y vino blanco, por separado. Añade también harina de trigo. Cuece todo, y aplica el producto resultante sobre la zona inflamada cuanto aguante, porque la hinchazón desaparece. ¡Permitalo Dios!

Si la inflamación tiende hacia la parte inferior de la boca, coge hierro aguzado como una uña, caliéntalo al rojo vivo y aplícalo por ambos lados [fol. 32r.] de la zona

79. Término de lectura incierta. Acaso pudiera ser una deformación de la palabra "estoraque" (lat. $\underline{\text { storax}}$, de donde "estiracáceo", Styrax officinalis). "Árbol de cuyo tronco se obtiene un bálsamo muy utilizado en medicina y también en perfumería" (María Moliner).

80. Font Quer (p. 819) dice: “Ajenjo (Artemisa absinthium). Sinonimia cast. absintio, axenxio, ajencio, asenjo, axenso... artemaga, alsamilla, donzell mascle o simplemente donzell. En cuanto a la morela (p. 583): "Hierba mora (Solanum nigrum). Sinonimia cast. tomatillos del diablo, tomates del diablo o simplemente, tomatillos [...] cat. morella". Maimónides (Glossaire 297): "La raíz de lobo, en beréber, varbaqnīna (verba canina)". Cf. nota 37. 
afectada en muchos sitios, según veas que es necesario o para que salga la pus. Unge después ésta dos veces al día con manteca de vaca derretida, porque la inflamación desaparece. ¡Permitalo Dios!

116. Sobre cómo curar la inflamación del nervio o de cualquier otra parte del cuerpo, ya se trate del ser humano, ya del animal.

Muele grasa de cerdo e higos blancos. Aplica el producto resultante sobre la zona, porque la inflamación cesa. ;Permítalo Dios!

117. Si quieres que salga la pus de toda herida.

Si aplicas sobre la herida raices de lirio molidas con un poco de miel, la pus sale aunque tenga la profundidad de un palmo.

118. Sobre la mancha blanca en los ojos del animal.

Tritura semillas de armuelle con 5 granos de pimienta. Espolvorea el producto resultante en los ojos de la bestia. Es cosa probada.

119. Sobre la uña en los ojos [... $]^{81}$. [fol. 32v.]

120. Sobre la reticulación.

Hipócrates dice: "Si la reticulación es de venas y flaqueza, cauteriza varias veces sucesivas la parte inferior del casco del caballo, -porque los cristianos cauterizan también con fuego después de haber enfriado, ya que es el mejor tratamiento existente para este ma-. La cauterización suave tras sangrar endurece el casco y cura todo daño derivado de la reticulación y la puntura ${ }^{82}$, entre los males que pueden afectarla a aquél”. ;Permítalo Dios! Otro aserto de Hipócrates: "Coge media arroba de vino bueno, cuece este con poleo y dáselo al animal tanto por vía oral como por vía nasal, porque se cura”. ¡Permítalo Dios! 121. Sobre la bestia derrengada y el derrengamiento.

Se trata de un mal que afecta a las espaldas del bruto, [fol. 33r.] que debe su causa a múltiples y diversas razones, aunque las más de las veces acaece por al-namīra ${ }^{83}$ o también puede deberse a sofocación y ahogo, los cuales al confluir, ejercen su presión en la espalda de la bestia.

81. Al manuscrito le falta una página.

82. Ibn al- $\quad$ 'Aww ām (II, p. 638) dice al respecto: "la 'puntura' en el interior del casco (dice Hipócrates el Veterinario) proviene de sangre corrompida por percusión en el casco, o por golpe; a veces es podre, y entonces es daño causado por piedra que se le haya fixado". En cuanto a la "reticulación", cf. nota 35.

83. No se documenta el término. 
Hipócrates afirma: "El derrengamiento puede sobrevenir como consecuencia de caída, contusión o por carga”.

Por lo que atañe a la flatulencia, también tiene su origen en una caída, un golpe o en la suscitación del ahogo. Cuando el animal se vea pues aquejado por alguno de estos males, trata como te voy a prescribir". ¿Quiéralo Dios!

\section{Un aserto de Hipócrates:}

"Cuando se suscitan a la vez al-namīra ${ }^{84}$ y flatulencia, efectúa una incisión grande en la zona afectada y aplica después aceite hirviendo, porque genera excelente beneficio. ¡Quiéralo Dios! Deja pasar treinta días, trata con fuego [fol. 33v.] y derrama después aceite de oliva, durante siete días. Aplica al cabo de ellos gachas durante dos noches, y retama molida, otras dos; y durante los siguientes siete días, botón de rosa con vinagre. Espolvorea finalmente sobre la zona mirto triturado".

123. Sobre el dolor de vientre que, en romance, se llama "torzón".

Hipócrates dice: "El dolor de vientre acaece ya por sofoco ya por ahogo, que tratarás como a continuación te indico. ¿Quiéralo Dios!: pon a cocer un polluelo, rápidamente extrae sus vísceras, añade un poco de agua caliente, y otro poco de comino, tritura todo e introdúcelo en la boca del animal”. ¿Quiéralo Dios!

124. Sobre el animal de montura.

Al-Hindiwān, que en romance se denomina "enredamiento" ".

Hipócrates dice: "Cuando la intensidad del sofoco suscita la calidez del ahogo, que es la fiebre en el animal, trata como a continuación te indico: [fol. 34r.] cauteriza

84. Ídem.

85.

La palabra hindiwān no se registra en los léxicos ni en diccionarios. Sin embargo sí cita este al Ibn Hudayl (fol. 35r): "al-Hunduwān es un final que deseca el cuerpo de la bestia debido al exceso de frío. Y, si le sobreviene en época de frío, es difícil que (el animal) se salve. Sus síntomas son: una sequedad que impide al animal volverse, contracción de nariz, que el animal deja de comer y de beber, si se le obliga a caminar arrastra los pies, dificultad para orinar, las orejas se le caen, los ojos hundidos. La causa fundamental que la origina es el frío intenso del invierno o estar el animal descubierto tras haber sudado mucho en un sitio frío o una herida en el hipocondrio". En cuanto al término romance "enredamiento", es masculino antiguo. "Enredo. Complicación y maraña que resulta de trabarse entre sí desordenadamente los hilos u otras cosas flexibles" (P. BARCIA, Diccionario General Etimológico, Barcelona, 1892). Se trataría de un "enredamiento" en este caso de las partes flexibles del cuerno de la bestia. Asimismo sigue diciendo el texto de Ibn Hudayl (fol. 350) de donde nuestro tratado puede haber tomado la fuente: "tratamiento: se toma el peso de una onza de laurel y se echa en los oídos de la bestia. A continuación cauteriza ésta en zona de confluencia de la espalda y la grupa y lógralo bien; luego sángralo en toda vena capaz de sangrar y mantenlo a su vez en una habitación en la que arda tamarisco a fin de que pueda aspirar el humo, permaneciendo así tres días consecutivos; y échale una brida para que la mastique (en la boca, porque tanto las venas) de su cabeza como las del cuello se relajarán". Otro procedimiento es: "se coge aceite enfreído, se pone en un recipiente, se deja hervir mucho y cauteriza con él a la bestia en cada articulación de su cuerpo: en la superficie del 
la bestia por la espalda y la grupa, lógralo bien y sángralo en toda vena capaz de sangrar, mantenlo a su vez en una habitación en la que arda tamarisco, a fin de que pueda aspirar bien el humo de su combustión, permaneciendo así tres días consecutivos, y si puedes echarle una brida de cabello que la muerda con la boca, tanto las venas de la cabeza como las del cuello se relajarán".

Otro procedimiento se basa en lo siguiente: pon en un recipiente aceite onfacino en gran cantidad, déjalo hervir al fuego en un recipiente nuevo y cauteriza con él cada una de las articulaciones del animal, lo primero de ello la superficie, el cuello de la bestia, a cuatro dedos de la nuca, la frente, el pecho y la parte exterior de las rodillas, [fol. 34v.] la de las articulaciones de ambos aditamentos ${ }^{86}$, la zona de confluencia de los lomos, la confluencia de las rodillas y las partes externas de las rótulas y de las articulaciones de los pies. Sangra, finalmente, las venas, porque se cura. iPermítalo Dios!

125. Sobre la puntura en la parte interna del pie de la bestia, que en romance recibe el nombre de "empedradura".

Hipócrates afirma: "Si se genera puntura en la pezuña de la bestia, introduce en ella una cánula prendida en el fuego. Pon a continuación, durante tres noches, gachas de habas con agua salada, y deja descansar al animal un día entero, porque se cura”. iPermítalo Dios!

\section{Sobre la sofocación o muermo.}

Hipócrates dice: "Si durante el invierno se suscita sofocación en el animal y no se pueden hacer insuflaciones, trata como le conviene, con el fin de reducir la fuerza y el vigor: coge col rizada de invierno, cuécela bien, extrae un arrate de su jugo, añádele su cuarto de aceite de oliva y mezcla todo. Aplica varias veces, cada día, el producto resultante por la nariz de la bestia, en la cantidad de dos candiles, porque la sofocación se reduce".

Otro procedimiento para cuando la sofocación se suscita y debilita al animal, impidiéndole comer y poniéndole en la agonía: degüella una gallina gruesa, desplú-

cuello, a cuatro dedos de la coronilla, en la frente, en el pecho y en la parte exterior de las rodillas; en la parte exterior de las articulaciones de los aditamentos y de las zonas de confluencia de los tendones, en la confluencia de las rodillas, en la parte exterior de las rótulas y en la parte exterior de las articulaciones del pie, aplicando una cauterización suave e intermedia; finalmente sangra después las venas en su totalidad". Finalmente, Ibn Ŷulŷul, en su Tratado sobre la tríaca, habla de esta misma enfermedad diciendo: "va bien para al-hindiwān que afecta a los caballos y la tos si se bebe de ella media onza con vino añejo" (edición y traducción I. Garijo, Córdoba, 1992, p. 58, quien traduce el término por "enfermedad india"). Cf. también en la Tesis Doctoral de I. GARIJO, La obra científica de Ibn Ŷulyul, Córdoba, 1991, vol. I, p. 339.

86. Es imposible precisar a qué aditamento se refiere el autor, si a los "lóbulos olfativos", "procesos articulares de las vértebras", etc. F.A. FONAHN, Arabic and latin anatomical terminology, Kristiania, 1922, p. 4 y ss. 
mala como si la fueses a comer, cuécela en agua salada, entera y sin abrirle el vientre, una vez cocida retírala del fuego y dásela como forraje al animal emanando aún el vapor de la cocción, porque la sofocación no sólo desaparece sino que no la vuelve a padecer en toda su vida. ¡Permitalo Dios!

\section{BIBLIOGRAFÍA}

Álvarez de Morales y Ruiz Matas, C., «Los animales en los textos agrícolas escritos en árabe», Miscelánea Arábica e Islámica, Leuven, 1993, pp. 143-163.

- «Un tratado granadino de hipiatría», Homenaje Prof. D. Cabanelas, Granada, 1987, II, pp. 305-312.

- «La zootecnia en los textos agrícolas árabes», Ciencias de la Naturaleza en al-Andalus, Granada, 1990, pp. 81-91.

- «Magia y superstición en la literatura agrícola andalusí», Ciencias de la Naturaleza en al-Andalus, Granada, 1994, II, pp. 391-403.

Álvarez de Morales, C. y Girón Irveste, F., Mujtașar fī-tiibb (Compendio de Medicina) de Ibn Habīa, Madrid, 1992.

Asín Palacios, M., Glosario de voces romances registradas por un botánico anónimo hispano-musulmán (siglos XII-XII), ed. facsímil, Zaragoza, 1994.

BANQUeRI, J.A., Libro de Agricultura de Aben Mohamed ben Ahmed ebn al Awam, edic. facsímil del Ministerio de Agricultura, Madrid, 1988.

BARCIA, R., Diccionario General Etimológico, Barcelona, 1880.

BARKIA, R. (en prensa).

CORRIENTE, F., Léxico estándar y andalusí del Dīwān de Ibn Quzmān, Zaragoza.

- El léxico árabe estándar y andalusí del Glosario de Leiden, Madrid, 1991.

-Árabe andalusí y lenguas romances, Madrid, 1992.

-A grammatical sketch of the spanish-arabic dialect bundle, Madrid, 1991.

-Relatos píos y profanos del ms. aljamiado de Urrea del Jalón, Zaragoza, 1990.

Diccionario crítico etimológico castellano e hispánico, Corominas J.-Pascual, J.A. Madrid, 1984.

Domínguez OrTiz, A. y Vicent, B., Historia de los moriscos. Vida y tragedia de una minoría, Madrid, 1978.

DozY, R., Supplément aux Dictionnaires Arabes, Leiden-París, 1927.

DUBLER, C.E. y TeRÉs, E., La materia médica de Dioscórides, Barcelona-Tetuán, 1952-1957.

EgUILAZ y YanguaS, L., Glosario etimológico de las palabras españolas de origen oriental, Madrid, 1974.

EISENSTEIN, H., «Las obras árabes de medicina veterinaria: ¿Tratados médicos o literatura edificante?», Actas XVI congreso UEAI, Salamanca, 1995, pp. 157-163.

FonAHN, F.A., Arabic and latin anatomical terminology, Kristiania, 1922.

FONT QuER, P, Plantas medicinales. El Dioscórides renovado, Barcelona, 1962. 
GARCÍA BALLESTER, L., Los moriscos y la medicina. Un capítulo de la medicina y la ciencia marginadas en la España del siglo XVI, Barcelona, 1984.

- Medicina, ciencia y minorías marginadas: los moriscos, Granada,1976.

Glosario de voces aljamiadas moriscas, Oviedo, 1994.

GRIFFIN, D.A., Los mozarabismos del Vocabulista atribuido a Ramón Martí, C.S.I.C., Madrid, 1961.

IBN HUDAYL, al-Fawāid al musațtara fīilm al-baytara (Provechos trazados de albeitería), Ms. XLIII, Colección Gayangos, Academia de la Historia.

IBN ŶULŶU, Tratado sobre los medicamentos de la tríaca, ed. y trad. I. Garijo, Córdoba, 1992.

IBN WĀFID, El libro de la almohada (Recetario médico árabe del siglo XI).

LABARTA, A., «Inventario de los documentos árabes contenidos en procesos inquisitoriales contra moriscos valencianos conservados en el archivo histórico nacional de Madrid (legajos 548-556)», al-Qanțara, 1980, I, fase. 1 y 2, pp. 152-153.

- «Textos para el estudio de la terapéutica entre los moriscos valencianos», Dynamis, I, 1981, pp. $275-310$.

- «Nuevas recetas médicas de moriscos valencianos», Dynamis, 7-8, 1987-88, pp. 348-354.

- Libro de dichos maravillosos (misceláneo morisco de magia y adivinación), Madrid, 1993.

LlaVEro Ruiz, E., Un tratado de cirugía hispanoárabe del siglo XIV: el kitāb al-istiqșā de Muḥammad al-Šafrā (Tesis doctoral Universidad de Granada, 1988).

LONGAS, P, Vida religiosa de los moriscos, Madrid, 1915.

MADOZ, P, Diccionario geográfico-estadístico-histórico de España y sus posesiones de ultramar, Madrid, 1846.

MAIMÓNIDES, Un glossaire de matière médicale, ed. M. Meyerhof, El Cairo, 1940.

MARTínez RuIZ, J., «Ensalmos curativos del manuscrito árabe “Misceláneo de Salomón” de Ocaña (Toledo), en el marco jurídico de convivencia de las tres culturas», Actas del II Congreso Internacional. Encuentro de las tres culturas, Toledo, 1985, pp. 217-227.

MENSCHING, G., La sinonimia de los nombres de las medeçinas griegos e latynos e arauigos, Madrid, 1994.

Millás VAllicrosa, J.M., «La tradición de la ciencia geopónica hispanoárabe», Estudios sobre historia de la ciencia española, vol. II, Barcelona, 1960.

Moliner, M., Diccionario de uso del español, Madrid, 1981.

SALVADOR, Gregorio, «Aragonesismos en el andaluz oriental», AFA V, 1953, pp. 249-322.

SAMSÓ, J., Las ciencias de los antiguos en al-Andalus, Madrid, 1992.

TERÉs SÁDABA, E., «Los manuscritos árabes de la Real Academia de la Historia. La colección Gayangos», al-Andalus, XL, 1975, pp. 23-63. 
VÁzQUEZ de BENITO, M.C., «Sobre un manuscrito árabe hallado en Alcázar de Consuegra», Sharq al-Andalus, 10-11, 1993-94, Homenaje a M. Jesús Rubiera, pp. 711-720.

- El manuscrito n. ${ }^{\circ}$ XXX de la Colección Gayangos, Madrid, 1974.

VÁzQuez de BENITO, M.C. y HeRreRA, M.T., «Problemas en la transmisión de arabismos», al-Qantara, IV, 1-2, 1983, pp. 151-174.

VINCENT, B., «L'Expulsion des morisques du Royaume de Granada et leur répartition en Castilla (1570-1571)», Mélanges de la casa de Velázquez, 6, 1970, pp. 211-246.

- «La expulsión de los moriscos del Reino de Granada y su reparto en Castilla», en Andalucía en la Edad Moderna, Granada, 1976.

- «Reflexión documentada sobre el uso del árabe y de las lenguas románicas en la España de los moriscos (ss. XVI-XVII)», Sharq al-Andalus, 10-11, 1993-94, Homenaje a M. ${ }^{a}$ J. Rubiera Mata, pp. $732-748$.

VigueRA Molins, M.J., Ibn Hudayl: gala de caballeros, blasón de paladines, Madrid, 1977.

- «Prólogo» a Relatos Piós y Profanos del ms. aljamiado de Urrea del Jalón, edic. F. Corriente, Zaragoza, 1990.

YAQŪT AL-RŪMī, Mu'ŷam al-Buldān, Beirut, 1979.

ZAMORA Vicente, A., Dialectología española, Madrid, 1989.

\section{RESUMEN}

Edición, traducción y análisis de un manuscrito morisco de tema médico y veterinario en árabe, perteneciente a la Biblioteca de la Facultad de Filología de la Universidad de Salamanca y hallado en Alcázar de Consuegra (i.e. Alcázar de San Juan [Ciudad Real]), de posible procedencia granadina a través de los moriscos expulsados tras la rebelión de las Alpujarras. Se analizan sus contenidos, sus fuentes árabes andalusíes, los procedimientos curativos reseñados y las características filológicas del texto.

Palabras clave: moriscos, literatura médica, medicina árabe, textos árabes.

\section{ABSTRACT}

Edition, translation and analysis of a morisco arabic manuscript on medical-veterinary subject. This manuscript is actually in the Library of the Faculty of Arts in the University of Salamanca and was found in Alcázar de Consuegra (i.e. Alcázar de San Juan [Ciudad Real]). Its origin is probably a group of moriscos expeled from Granada after the revolt of the Alpujarras. We analyze its contents, andalusi sources, curative procederes and also its philological traits.

Key words: Moriscos, medical literature, arabic medicine, arabic texts. 